UNIVERSIDADE DE SÃO PAULO

FACULDADE DE ECONOMIA, ADMINISTRAÇÃO E CONTABILIDADE DEPARTAMENTO DE ADMINISTRAÇÃO PROGRAMA DE PÓS-GRADUAÇÃ̃ EM ADMINISTRAÇÃO

Giorgia Chimara Varzoni

GESTÃO ESTRATÉGICA DE RECURSOS HUMANOS E RELAÇÕES DE TRABALHO: UM ESTUDO EM EMPRESAS DO SETOR DE REFEIÇÕES COLETIVAS DO ESTADO DE SÃO PAULO 
Prof. Dr. Vahan Agopyan

Reitor da Universidade de São Paulo

Prof. Dr. Fábio Frezatti

Diretor da Faculdade de Economia, Administração e Contabilidade

Prof. Dr. Moacir de Miranda Oliveira Júnior

Chefe do Departamento de Administração

Prof. Dr. Eduardo Kazuo Kayo

Coordenador do Programa de Pós-Graduação em Administração 


\title{
GESTÃO ESTRATÉGICA DE RECURSOS HUMANOS E RELAÇÕES DE TRABALHO: UM ESTUDO EM EMPRESAS DO SETOR DE REFEIÇÕES COLETIVAS DO ESTADO DE SÃO PAULO
}

\author{
Versão corrigida \\ (Versão original encontra-se na unidade que aloja o Programa de Pós-graduação)
}

Dissertação apresentada ao Departamento de Administração da Faculdade de Economia, Administração e Contabilidade da Universidade de São Paulo, como parte dos requisitos para obtenção do título de Mestre em Ciências.

Área de concentração: Gestão de Pessoas

Orientador: Prof. Dr. Wilson Aparecido Costa de Amorim

São Paulo 
Autorizo a reprodução e divulgação total ou parcial deste trabalho, por qualquer meio convencional ou eletrônico, para fins de estudo e pesquisa, desde que citada a fonte.

Varzoni, Giorgia.

Gestão estratégica de recursos humanos e Relações de Trabalho: um estudo em empresas do setor de refeições coletivas do estado de São

Paulo. / Giorgia Varzoni. - São Paulo, 2019. $108 \mathrm{p}$.

Dissertação (Mestrado) - Universidade de São Paulo, 2019. Orientador: Wilson Aparecido Costa de Amorim.

1. Gestão estratégica de recursos humanos. 2. Relações de trabalho. 3. Gestão de pessoas. 4. Unidades de alimentação e nutrição. 5. Nutrição. I. Universidade de São Paulo. Faculdade de Economia, Administração e Contabilidade. II. Título. 
Nome: Giorgia Chimara Varzoni

Título: Gestão Estratégica de Recursos Humanos e Relações de Trabalho: um estudo em empresas do setor de refeições coletivas do estado de São Paulo.

Dissertação apresentada ao Departamento de Administração da Faculdade de Economia, Administração e Contabilidade da Universidade de São Paulo, como requisito para obtenção do título de Mestre em Administração.

Data de aprovação:

Banca Examinadora

Prof. Dr.

Instituição:

Julgamento:

Prof. Dr.

Instituição:

Julgamento:

Prof. Dr.

Instituição:

Julgamento: 

À Deus, ao meu marido Ícaro, aos meus filhos Sofia e Enzo e à minha mãe Maddalena. 



\section{AGRADECIMENTOS}

Agradeço primeiramente a Deus por me proporcionar esta oportunidade e me capacitar a cada etapa desta jornada. Ao meu marido Ícaro pelo incentivo, apoio, compreensão, carinho, ouvido e ombro em todos os momentos. Ao professor Wilson pelos ensinamentos, orientação e confiar no meu potencial antes mesmo de eu saber que os tinha. Aos meus sogros Lídia e Mauricio agradeço por estarem com meus filhos em meu lugar durante minha ausência. À minha mãe Maddalena pelo seu cuidado, carinho e responsabilidade com meus estudos e por me lembrar sempre que sou capaz. Ao meu irmão Henrique e cunhada Marília agradeço o apoio, o compartilhamento de suas experiências de mestrado e interesse em saber como tudo estava no andamento do curso. Aos meus amigos e irmãos na fé que me ajudaram e oraram por mim no decorrer deste tempo.

Obrigada Patricia Logullo e Selene Pedroso pelas revisões e orientações que tornaram meu texto muito melhor. Aos professores André Luiz Fischer e Elza Fátima Velozo pelas contribuições e orientações na etapa de qualificação desta pesquisa. Ao Marcos Aurélio pelas orientações no uso da ferramenta da base de dados da RAIS. Agradeço a cada professor das disciplinas que cursei e colegas que contribuíram para que meu conhecimento aumentasse. À cada entrevistado que dedicou seu tempo em me contar sobre as empresas e sindicatos em que trabalham e forneceram informações fundamentais para este trabalho.

A cada um agradeço com todo meu coração, pois de alguma forma contribuíram para que esta dissertação pudesse ser realizada. Deus os abençoe sempre. 



\section{RESUMO}

Varzoni, G.C. (2019). Gestão estratégica de recursos humanos e relações de trabalho: um estudo em empresas do setor de refeições coletivas do estado de São Paulo. (Dissertação de Mestrado). Faculdade de Economia, Administração e Contabilidade da Universidade de São Paulo, São Paulo.

Este estudo objetivou principalmente identificar e analisar a gestão estratégica de pessoas nas empresas de restaurantes de refeições coletivas no estado de São Paulo, tendo como foco as relações de trabalho. As finalidades específicas deste trabalho foram investigar quanto as empresas de refeições coletivas adotam políticas e práticas de gestão estratégica de RH, identificar e analisar as características específicas de relações de trabalho e relacionar as características das relações de trabalho com a adoção de práticas estratégicas de RH por estas organizações. Os pontos de partida teóricos foram a gestão estratégica de RH e as relações de trabalho. Sobre gestão estratégica de RH, abordou-se os temas de gestão de pessoas e modelos de gestão de pessoas. A discussão teórica sobre relações de trabalho abordou a evolução deste constructo, os sistemas de relações de trabalho e as relações de trabalho no Brasil. Por meio de levantamento bibliográfico de publicações recentes, foram analisados onze artigos científicos que discutem aspectos da gestão estratégica de RH e das relações de trabalho. A pesquisa realizada foi qualitativa, descritiva e exploratória. O estudo empírico investigou as atividades de quatro grandes empresas de refeições coletivas do estado de São Paulo. Realizou-se coleta de dados por meio de análise documental, entrevistas semiestruturadas com gestores de RH e sindicalistas, e análise de base dados secundária. Os resultados da pesquisa demonstraram que as empresas de refeições coletivas apresentam características de gestão estratégica de RH e possuem uma relação de trabalho baseada em boa interação entre sindicatos dos trabalhadores, empregados e empresa. Demonstrando, assim, que as relações de trabalho das empresas de refeições coletivas podem contribuir para a atuação de uma gestão estratégica de RH.

Palavras-chave: Recursos humanos. Gestão de pessoas. Gestão estratégica de recursos humanos. Relações de trabalho. Nutrição. Unidade de alimentação e nutrição. 


\begin{abstract}
Varzoni, G.C. (2019). Strategic human resource management and labor relations: a study in collective meal sector companies in the state of São Paulo. (Dissertação de Mestrado). Faculdade de Economia, Administração e Contabilidade da Universidade de São Paulo, São Paulo.
\end{abstract}

This study aimed to identify and analyze the strategic human resource (HR) management in collective meal restaurant companies in the state of São Paulo focusing on labor relations. The specific purposes of this paper were to investigate how collective meal companies adopt strategic HR management policies and practices, identify and analyze the specific characteristics of labor relations, and relate the characteristics of labor relations to the adoption of strategic HR practices by those organizations. The theoretical starting points were strategic HR management and labor relations. On strategic HR management, the topics of people management and people management models were addressed. The theoretical discussion about labor relations addressed the evolution of this construct, labor relations systems and labor relations in Brazil. Through a bibliographic survey of recent publications, we have analyzed eleven scientific articles that discuss aspects of strategic HR management and labor relations. The research was qualitative, descriptive and exploratory. The empirical study investigated the activities of four large collective meal companies in the state of São Paulo. Data collection was performed through document analysis, semistructured interviews with HR managers and union members, and secondary database analysis. The research results showed that collective meal companies have characteristics of strategic HR management and have a labor relations based on good interaction between workers, employees and unions. Hence, demonstrating that the labor relations of collective meal companies can contribute to the performance of strategic HR management.

Keywords: Human Resource. People management. Strategic human resource management. Labor relations. Nutrition. Collective meals. 
$\begin{array}{ll}\text { 1. INTRODUÇÃO } & 17\end{array}$

$\begin{array}{ll}1.1 \text { Justificativa } & 17\end{array}$

$\begin{array}{ll}\text { 1.2 Questão do estudo } & 19\end{array}$

$\begin{array}{ll}1.3 \text { Objetivos da pesquisa } & 19\end{array}$

2. REFERENCIAL TEÓRICO 21

2.1 Gestão de pessoas $\quad 21$

$\begin{array}{ll}\text { 2.1.1 Gestão estratégica de recursos humanos } & 23\end{array}$

$\begin{array}{ll}\text { 2.1.2 Modelos de gestão de pessoas } & 28\end{array}$

2.1.3 Relações de trabalho 36

2.1.4 Estudos recentes sobre GERH e relações de trabalho: uma breve análise $\quad 41$

2.2 Síntese conceitual 47

3. POSIÇÕES METODOLÓGICAS

3.1 Método de pesquisa 51

3.2 Planejamento operacional 52

3.2.1 Procedimentos de revisão de bibliografia 52

3.2.2 Coleta de Dados 53

3.2.2.1 Análise documental 53

3.2.2.2 Análise de dados de fontes secundárias $\quad 54$

3.2.2.3 Entrevistas semiestruturadas $\quad 54$

$\begin{array}{ll}3.3 \text { Interpretação e análise } & 57\end{array}$

4. RESULTADOS E ANÁLISE DOS DADOS 63

4.1 O setor de refeições coletivas no Brasil 63

4.1.1 A alimentação 63 
4.2 Descrição das organizações estudadas

4.3 $\mathrm{O} \mathrm{RH}$ e as relações de trabalho nas empresas estudadas

4.3.1 Empresa Alpha

4.3.2 Empresa Beta

4.3.3 Empresa Gamma

4.3.4 Empresa Delta

4.3.5 Os sindicatos do setor

4.4 Discussão dos resultados

5. CONSIDERAÇÕES FINAIS

6. REFERÊNCIAS BIBLIOGRÁFICAS

99

APÊNDICES 


\section{LISTA DE TABELAS}

Tabela 1 Modelos de gestão de pessoas.

Tabela 2 Síntese dos conceitos e discussões apresentados no refencial teórico.

Tabela 3 Resultados da pesquisa bibliométrica em revistas nacionais.

Tabela 4 Definições conceituais, operacionais e questões para as entrevistas.

Tabela 5 Variáveis independentes e questões da pesquisa.

Tabela 6 Dados dos entrevistados.

Tabela 7 Dados das entrevistas.

Tabela 8 Faturamento em bilhões de reais do setor de alimentação coletiva no Brasil de 2010 até 2017.

Tabela 9 Distribuição por subsetor da quantidade de refeições em milhões/dia no Brasil de 2010 até 2017.

Tabela 10 Número de trabalhadores do setor de refeições coletivas no Brasil de 2015 a 2017.

Tabela 11 Número de trabalhadores do setor de refeições coletivas segundo o sexo no estado de São Paulo em 2017.

Tabela 12 Faixa etária (anos) dos trabalhadores do setor de refeições coletivas no estado de São Paulo em 2017.

Tabela 13 Escolaridade dos trabalhadores do setor de refeições coletivas segundo escolaridade no estado de São Paulo em 2017.

Tabela 14 Distribuição do número de trabalhadores segundo a remuneração mensal média (R\$) no estado de São Paulo em 2017.

Tabela 15 Distribuição do número de trabalhadores do setor de refeições coletivas segundo tempo de trabalho (meses), no estado de São Paulo em 2017. 
Tabela 16 Principais cláusulas da Convenção Coletiva 2018/2019 do setor de refeições

coletivas.

Tabela 17 Síntese das descrições das empresas de refeições coletivas entrevistadas. $\quad 79$ Tabela 18 Síntese das respostas das entrevistas com gestores de RH sobre gestão de RH e relações de trabalho.

Tabela 19 Síntese dos dados das entrevistas com sindicalistas do setor de refeições coletivas do estado de São Paulo. 


\section{LISTA DE FIGURAS}

Figura 1 Principais stakeholders e o valor esperado. 24

Figura 2 Análise das capacidades organizacionais 25

Figura 3 Modelo teórico sobre as configurações de RH 31

Figura 4 Arquiteturas de RH 32

Figura 5 Visão geral da organização de RH. 41

Figura 6 Alinhamento entre a organização do negócio e a organização do RH. $\quad 42$

Figura 7 Componentes da análise de dados: modelo interativo. 58 



\section{INTRODUÇÃO}

As empresas de refeições coletivas são organizações que fornecem serviços de alimentação para os trabalhadores de uma outra instituição. A atuação do setor de refeições coletivas nas empresas possui grande importância para o processo produtivo do negócio. Uma boa alimentação é indispensável para manter a produção e a eficiência do trabalho dos funcionários que recebem parte ou toda a alimentação diária fornecida dentro da empresa (Mesomo, 1994). A relevância deste setor na economia nacional é considerável, pois emprega 193 mil pessoas (RAIS, 2018) e possui um faturamento anual de R $\$ 18$ bilhões (ABERC, 2018).

A gestão de recursos humanos permite a conciliação das expectativas dos empregados e da organização, através de um conjunto de políticas e práticas (Dutra, Dutra \& Dutra, 2017). Existem fatores externos que também determinam o desempenho que se espera das pessoas no trabalho e a gestão de recursos humanos, destacando-se as relações de trabalho, sua legislação trabalhista e os agentes que atuam nesta relação, como as instituições sindicais. Estes fatores vão estabelecer os limites nos quais a gestão de recursos humanos poderá atuar (Fischer, 2002). A existência de diversos sindicatos de trabalhadores, legislações e relações de trabalho envolvidos na atividade do setor de empresas de refeições coletivas, torna significativa a análise da atuação da área de recursos humanos e das relações de trabalho neste contexto por este estudo. Espera-se, com esta pesquisa, contribuir para o aumento do conhecimento na área de gestão de recursos humanos em empresas de refeições coletivas, oferecendo ao setor e aos sindicatos dos trabalhadores mais informações para suas ações decisórias.

\subsection{Justificativa}

A gestão estratégica de recursos humanos $(\mathrm{RH})^{1}$ tem como objetivo alinhar as estratégias de recursos humanos com as estratégias da organização, ela é o modelo de implantações e atividades planejadas de recursos humanos destinadas a permitir que uma organização alcance suas metas (Wright \& McMahan, 1992). A adaptação da gestão

\footnotetext{
${ }^{1}$ Optamos por utilizar a expressão "recursos humanos" por uma questão de uniformização e alinhamento com a literatura internacional. Trataremos deste assunto mais adiante.
} 
estratégica de RH às necessidades de cada empresa é muito importante, porque soluções padronizadas são insuficientes e incapazes de atender a qualquer empresa em qualquer tempo (Fischer, 2015). Sendo assim, para entender a gestão de recursos humanos, torna-se importante, resgatar casos específicos, como os de determinado setor ou empresa. Portanto a abordagem teórica para este estudo será a contingencial, pois os fatores de contingência influenciam a gestão estratégica de RH devido à especificidade do negócio.

A opção pelo setor de empresas de refeições coletivas justifica-se pela dimensão e a importância deste setor na economia nacional são relevantes, conforme os números gerados pelo segmento no ano 2017. O mercado de refeições coletivas como um todo forneceu 12 milhões de refeições/dia, movimentou R \$ 18 bilhões por ano, ofereceu 210 mil empregos diretos, consumiu diariamente um volume de 7 mil toneladas de alimentos e representou para os governos uma receita de 2,5 bilhões de reais anuais entre impostos e contribuições, segundo ABERC (2018), Associação Brasileira de Empresas de Refeições Coletivas.

A relação da atividade de recursos humanos e o setor de refeições coletivas é relevante. O desempenho profissional dos seus empregados pode prejudicar a qualidade dos serviços e produtos (Teixeira et al, 2000). A atividade dos profissionais de uma organização é gerida pela área de RH e existe ampla linha de pesquisa a respeito do comportamento de gestão de pessoas em várias áreas produtivas. As relações de trabalho, bem como suas legislações e intervenções dos seus agentes, como o Estado e as instituições sindicais, são fatores externos advindos da sociedade que exercem um papel de restrição à gestão de recursos humanos. Estes fatores definem os limites até os quais as organizações e seus gestores decidem sobre suas políticas e práticas (Fischer, 2002). Desta forma, verifica-se a influência que as relações de trabalho podem exercer sobre a gestão de $\mathrm{RH}$, sendo o motivo pelo qual definiu-se também a pesquisa deste conceito no setor estudado.

Fischer (2015) afirma que a produção científica nacional e internacional é escassa em casos específicos que reconheçam, por meio da pesquisa, aquilo que efetivamente as organizações adotam na gestão de suas relações com seus empregados. Constatou-se na pesquisa bibliométrica deste estudo que esta carência de pesquisas persiste. Existe pouco conhecimento acumulado sobre a forma como as áreas de gestão de RH desenvolvem suas atividades no setor de empresas de refeições coletivas especificamente. Ao buscarmos na literatura a produção sobre "gestão estratégica de recursos humanos", "relações de trabalho" e "empresas de refeições coletivas", verificamos pouca exploração pelas pesquisas no campo em termos conceituais, e/ou em termos das práticas da área de alimentação, conforme apresentado no subcapítulo 3.2.1. 
1.2 Questão do estudo

A partir das reflexões teóricas relativas ao tema proposto, elaborou-se a seguinte pergunta de pesquisa:

Como se apresenta a gestão estratégica de recursos humanos vinculada às relações de trabalho em empresas de refeições coletivas?

\subsection{Objetivos da pesquisa}

Estabeleceu-se como objetivo principal da pesquisa identificar e analisar a gestão estratégica de recursos humanos nas empresas de refeições coletivas no estado de São Paulo, tendo como foco as relações de trabalho.

Como objetivos específicos deste estudo, definem-se:

a. Investigar e analisar as empresas de refeições coletivas quanto à adoção de políticas e práticas de gestão estratégica de RH;

b. Identificar e analisar as características específicas de relações de trabalho nessas organizações;

c. Relacionar as características das relações de trabalho com a adoção de práticas estratégicas de RH por estas organizações.

Diante desse cenário, a pesquisa pretende levantar dados existentes no mercado de trabalho, na área de refeições coletivas, para que se conheça sobre as políticas e práticas de gestão estratégica de $\mathrm{RH}$, e as relações de trabalho realizadas dentro da estrutura organizacional e sua influência sobre a empresa. No próximo capítulo, abordaremos o referencial teórico dos conceitos que embasarão esta pesquisa, gestão estratégica de pessoas e relações de trabalho. 


\section{REFERENCIAL TEÓRICO}

O capítulo teórico deste trabalho está orientado a discutir os conceitos de gestão estratégica de recursos humanos e relações de trabalho, que estão inseridos no campo de conhecimento de recursos humanos, e se conclui com uma tabela resumindo as principais definições destes conceitos.

\subsection{Gestão de pessoas}

Gestão de pessoas caracteriza-se como um conjunto de políticas e práticas que permitem a conciliação de expectativas entre a organização e as pessoas, para que ambas possam realizá-las ao longo do tempo (Dutra et al, 2017).

A mudança da utilização do termo "recurso" para "pessoas" ocorreu porque o papel do homem no trabalho vem se transformando (Fischer, 2001). O saber, a intuição e a criatividade do trabalhador passaram a ser valorizadas. A gestão é feita das relações da empresa com as pessoas e não com os recursos, o que demonstra a transição para uma realidade empresarial diversa. O uso da palavra "pessoas" procura ressaltar o caráter de ação com foco nas pessoas da organização. De acordo com Amorim (2017), na literatura internacional, encontrou-se somente a utilização do termo "recursos humanos", portanto, para este trabalho, optou-se por utilizar esta expressão para alinhamento com bibliografia.

Fischer (2002) descreve o histórico desses termos. A administração de recursos humanos é resultado do desenvolvimento empresarial e da evolução da teoria organizacional nos Estados Unidos. O autor relata que o conceito de recursos humanos refletia, antes da década de 1930, a imagem de uma área de trabalho voltada principalmente para as transações processuais e trâmites burocráticos. Após esse período, predominou a linha behaviorista do Instituto de Relações Humanas da Universidade de Yale, que criou instrumentos e métodos de avaliação e desenvolvimento de pessoas nas empresas. A história da human resource management (HRM) nos Estados Unidos iniciou-se em 1890, quando uma Empresa denominada NCR Corporation criou seu personnel office. A separação da teoria e da prática começou a ser percebida com o aparecimento de escolas marcadas pela influência da psicologia humanista. Fischer (2002) acrescenta que a partir dos anos de 1920, Elton Mayo e seus seguidores promoveram as primeiras experiências de contato mais intenso entre a administração e a psicologia, determinando uma nova fase na história da administração de 
recursos humanos. Nos anos 1930, Abraham Maslow iniciou um período em que a psicologia humanista passaria a interferir decisivamente na teoria organizacional.

Fischer (2002) prossegue explicando que a expressão human resource management começou a ser utilizada a partir de 1950 nos Estados Unidos para designar uma expansão da tradicional administração de pessoal (Springer \& Springer, 1990 citado por Fischer, 2002). Nos anos 1960 e 70, a escola de relações humanas predominou como matriz do conhecimento em gestão de pessoas. O modelo de recursos humanos passou a corresponder a uma nova fase dos processos de gerenciamento de pessoas, na qual a principal diferença está na postura do gerente na condução das equipes de trabalho. Nas décadas de 1970 e 80 foi introduzido nos sistemas de gestão de recursos humanos o caráter estratégico (Fischer, 2002).

Ulrich et al (2013) também descrevem o desenvolvimento da área de RH sob outro ponto de vista, classificando-o a partir de quatro ondas de evolução. As três primeiras ondas ocorreram a partir da metade do século XX e a quarta onda em meados dos anos $2010 \mathrm{em}$ diante. Conforme o mesmo autor, a primeira onda enfatizou o trabalho administrativo do RH, com o pessoal da área concentrado em termos e condições de trabalho, entrega dos serviços e conformidade regulamentar. O RH era descrito como "utilidade administrativa transacional”. A segunda onda enfatizou o projeto de práticas inovadoras no suprimento, remuneração ou recompensas, aprendizado, comunicação e assim por diante. As práticas de RH inovadoras e agregadoras e a credibilidade do RH demonstraram a eficácia da área durante esta onda. A terceira onda concentrou-se na conexão de práticas de RH individuais e agregadoras com o sucesso do negócio através do RH estratégico. Esse trabalho ampliou as funções de RH de seu foco original em talento para incluir contribuição para cultura e liderança. A quarta onda utilizou práticas de RH que respondam às condições externas do negócio com uma visão de futuro para fora das organizações. A eficácia do RH aparece no share de clientes, na confiança do investidor e na reputação na comunidade. A credibilidade do RH será obtida tanto dos que estão fora quanto dentro da empresa.

Ulrich et al. (2013) apontam seis paradoxos nas ondas de evolução do RH. Os autores denominam de paradoxos porque o pessoal e os departamentos de RH somente são eficientes quando entregam vários resultados simultaneamente. O primeiro deles é o de "fora e dentro", que significa transformar as tendências externas do negócio e as expectativas dos stakeholders em práticas e ações internas do RH. O próximo paradoxo é denominado pelos autores como "empresa e pessoas", tendo como objetivo adquirir a confiança das pessoas na organização e obter uma posição ativa no desempenho da empresa. O terceiro é denominado 
"organização e indivíduo", que apontam como sendo importantes para o sucesso da empresa, a maneira como as pessoas trabalham juntas e a cultura da organização. Para atingir positivamente este paradoxo é preciso encontrar a combinação correta de ações de desenvolvimento pessoal e da instituição. O quarto paradoxo se apresenta como "processo e evento" e ocorre quando o RH gera soluções sustentáveis e integradas. A sustentabilidade exige uma visão de longo prazo, uma solução integrada, combinando eventos isolados em soluções coesas. O quinto paradoxo é denominado "futuro e passado", o que significa que o RH é campeão de mudanças, conectando passado e futuro, antecipando e administrando iniciativas individuais e mudanças institucionais. O sexto e último paradoxo é o estratégico e administrativo", em que se reforça a ideia de que o RH precisa se tornar estratégico na adaptação dos futuros cenários do negócio, utilizando-se de tecnologia para processar o trabalho administrativo ao mesmo tempo em que gera informação para um trabalho mais estratégico.

Observa-se que Fischer (2002) e Ulrich et al (2013) apresentam a evolução e o desenvolvimento da área de RH de forma complementar, abordando a história desta área de conhecimento bem como seus avanços ao longo do tempo. O progresso da área de gestão de pessoas nos mostra a inserção do conceito de estratégia para esta área do negócio. Sendo assim, o próximo subcapítulo descreverá este conceito e seu desenvolvimento.

\subsubsection{Gestão estratégica de recursos humanos}

GERH tem como objetivo alinhar as estratégias de recursos humanos com as estratégias da organização, é o modelo de implantações e atividades planejadas de recursos humanos destinadas a permitir que uma organização alcance suas metas (Wright \& McMahan, 1992). Estratégia é a maneira com que os líderes fazem escolhas com objetivo de obter sucesso para a empresa em um contexto de negócio em transformação, com stakeholders específicos (Ulrich et al, 2013). Os autores descrevem stakeholders como sendo os clientes, os investidores, as comunidades, os parceiros, os gerentes e os empregados, conforme detalhado na figura 1 adiante, acrescentando a expectativa de cada tipo de stakeholder. Portanto, a Empresa deve investir nas pessoas para obter melhores resultados. A atuação somente funcional da gestão de pessoas nos ajuda a compreender o posicionamento relativo dela na organização, mas falta outra dimensão, que é a forma como a gestão de pessoas interage com as demais funções organizacionais e como as políticas e práticas que a compõem interagem entre si, de acordo com Dutra (2002). 
Figura 1 Principais stakeholders e o valor esperado.

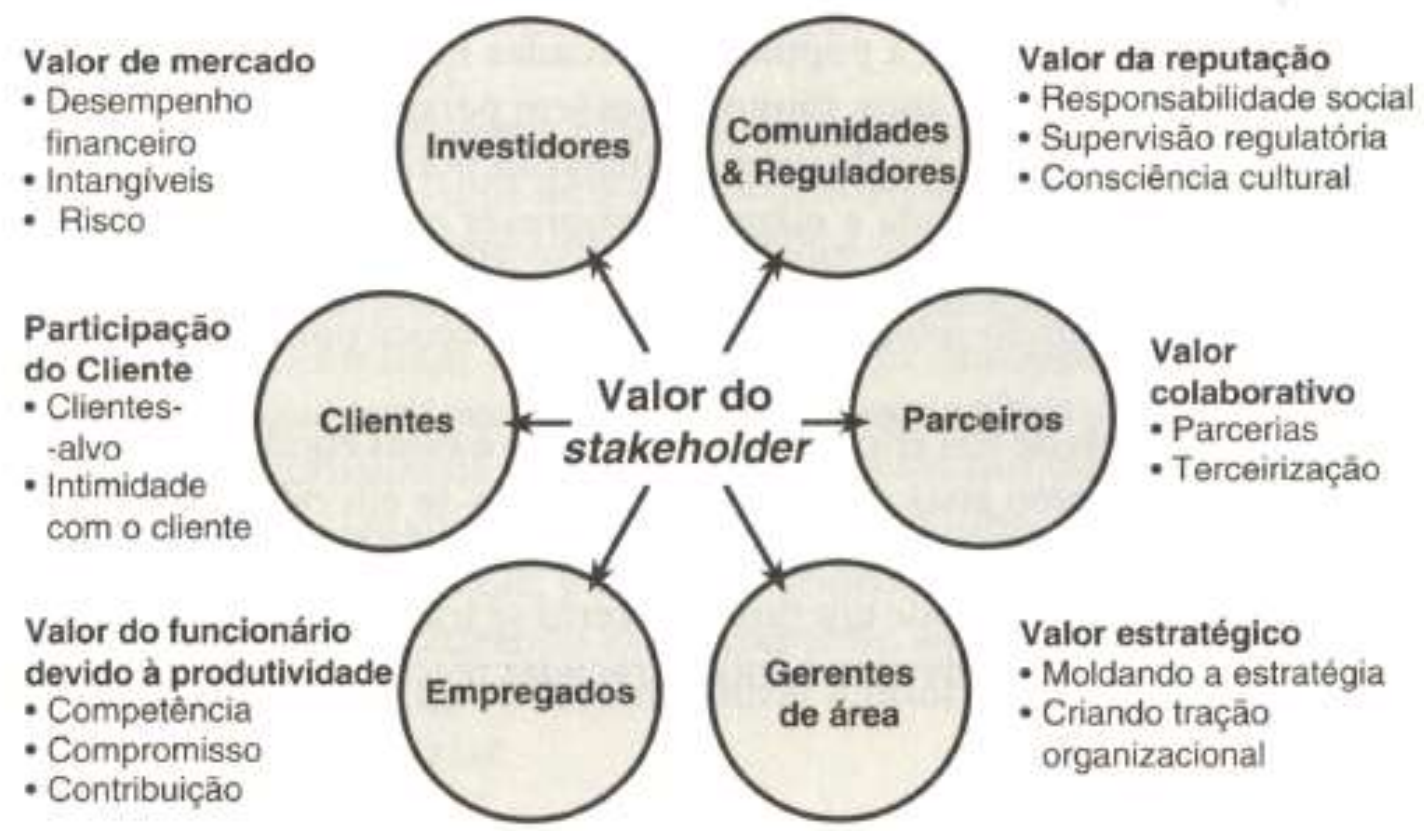

Fonte: Reproduzido de Ulrich et al. (2013).

As características da administração da estratégia de recursos humanos, de acordo com Anthony, Perrewé, e Kacmar (1996), são: que ela reconhece os impactos do ambiente organizacional externo; reconhece o impacto da competição e da dinâmica do mercado de trabalho; apresenta foco no longo prazo; enfatiza a escolha e a tomada de decisão; considera todas as pessoas da empresa, e não apenas o grupo de executivos ou o de empregados operacionais; e está integrada com a estratégia corporativa e com as demais estratégias funcionais. Segundo Albuquerque (2002), a análise das capacidades organizacionais identifica as forças e fraquezas da organização diante do planejamento estratégico. A eficiência positiva da organização diante de novas oportunidades depende da capacidade das pessoas que ali trabalham. A análise das capacidades organizacionais abrange $\mathrm{o}$ entendimento da estrutura da empresa, de seus sistemas e processos, dos seus trabalhadores e da sua cultura, conforme demonstrado na Figura 2. O mesmo autor complementa que a estratégia de recursos humanos deve seguir as etapas do processo de formulação e execução da estratégia corporativa, baseando- se na visão do negócio para desenvolver as diversas etapas do plano funcional que irão integrar a estratégia da organização. Torna-se importante realizar uma retroalimentação contínua de informações de diversas fases do processo através de avaliações de resultados ao longo do seu desenvolvimento. 
Figura 2 Análise das capacidades organizacionais

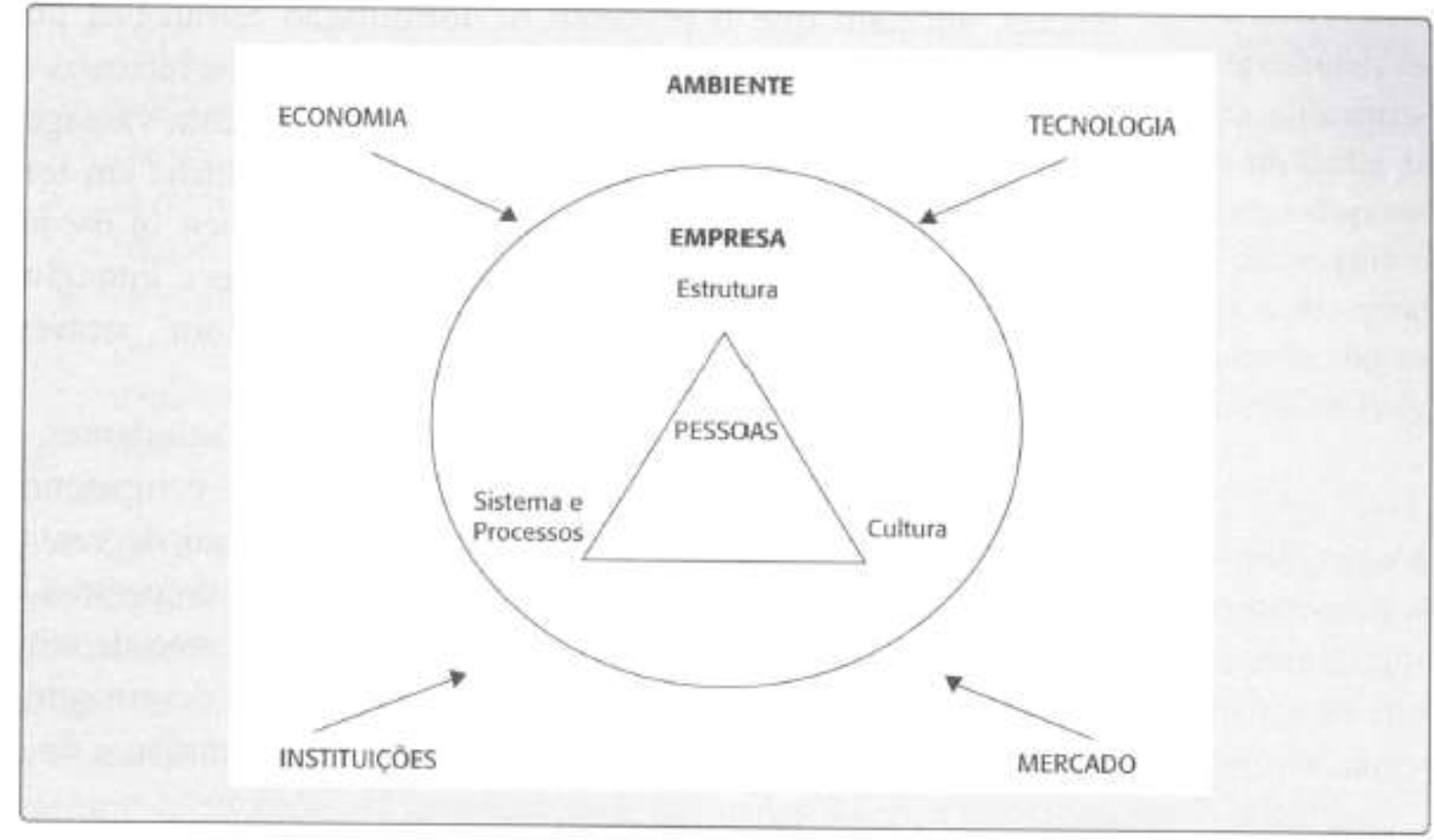

Fonte: Reproduzido de Albuquerque (2002).

A expressão "estratégia de recursos humanos" surgiu na literatura internacional no início da década de 1980 com alegações críticas ao papel funcional da área e demonstrando a natureza estratégica de recursos humanos e sua gestão (Albuquerque, 2002). Iniciou-se na década de 1990 a discussão da importância do processo de formulação da estratégia e sua relação com a gestão de RH e abordavam as dificuldades da implantação das diretrizes estratégicas do negócio (Lengnick-Hall et al, 2009). Alguns estudos e discussões serão apresentados a seguir.

Uma discussão interessante foi vinculada à relação entre sistemas de trabalho de alto desempenho (high performance work sistems - HPWS) e o desempenho da empresa foi iniciada por Huselid (1995). Os sistemas de trabalho de alto desempenho foram definidos como aqueles que incluem o recrutamento abrangente de funcionários e procedimentos de seleção, compensação de incentivo e sistemas de gestão de desempenho, e extenso envolvimento dos empregados e treinamento. Huselid descobriu que a relação entre as HPWSs e o desempenho financeiro das empresas era mediada pela rotatividade e produtividade. As HPWSs reduzem a rotatividade de funcionários e aumentam a produtividade, tendo, assim, um efeito positivo no resultado financeiro da organização (Lengnick-Hall, 2009). 
Delery e Doty (1996) propõem que a gestão estratégica de pessoas pode apresentarse de três formas: universalista, contingencial e configuracional, que ficaram conhecidas como formas de se estabelecer o " $f i t$ " ou alinhamento. A abordagem universalista defende a adoção das melhores práticas. Argumenta-se que algumas práticas de RH são sempre melhores do que as outras e que todas as organizações devem adotar estas melhores práticas. Os autores estabeleceram sete práticas importantes: oportunidades internas de carreira, sistemas formais de treinamento, medidas de avaliação, participação nos lucros, segurança no emprego, mecanismos de voz e definição de cargos. A perspectiva contingencial argumenta que, para serem eficazes, as políticas de RH de uma organização devem ser consistentes com outros aspectos da organização. As práticas de RH são consistentes com diferentes posições estratégicas e essas práticas se relacionam com o desempenho da empresa. A modalidade configuracional sugere que, para que o RH consiga atingir seus objetivos de forma eficaz, deve desenvolver um sistema que se adapte horizontalmente e verticalmente. $\mathrm{O}$ ajuste horizontal à consistência interna das políticas ou práticas de $\mathrm{RH}$ da organização e a adequação vertical referem-se à coerência do sistema de RH com as características organizacionais. Para este estudo, definiu-se a utilização da abordagem contingencial, pois se adequa melhor ao contexto do setor de refeições coletivas, aonde fatores contingenciais referentes à especificidade do negócio influenciam as práticas de RH.

Nesta mesma década, a teoria da visão baseada em recursos (VBR) se tornou dominante para a área de gestão estratégica de RH. Explicou-se como a visão baseada em recursos da firma poderia ser aplicada para gestão estratégica de RH. Boxall (1998) definiu o construto da vantagem de recursos humanos como consistindo em dois componentes: vantagem de capital humano e vantagem dos processos organizacionais. A vantagem do capital humano resulta de ter pessoas melhores que os concorrentes, enquanto a vantagem dos processos organizacionais resulta de melhores formas de trabalhar em relação aos concorrentes (Lengnick-Hall et al, 2009).

Wright e Snell (1998) afirmaram que a estratégia deve se encaixar em três variáveis conceituais genéricas: práticas de gestão de recursos humanos, habilidades dos funcionários e comportamentos dos funcionários. Lengnick-Hall et al (2009) definiram a flexibilidade como uma medida de recursos humanos para buscar alternativas estratégicas no mercado competitivo da empresa e discutem até que ponto as práticas necessárias de gestão de $\mathrm{RH}$ podem ser identificadas, desenvolvidas e implementadas para maximizar esta flexibilização.

Legge (2005) discute duas abordagens para a gestão de RH. A autora os denomina de modelo "hard" e modelo "soft". O modelo "hard" representa a atividade instrumental de 
RH, a integração das políticas, dos sistemas e das atividades de RH com os objetivos da organização. O modelo "soft" é voltado para o desenvolvimento humano; além de integrar política de RH com os objetivos da organização, entende que os empregados são um recurso para a vantagem competitiva através do comprometimento, adaptabilidade e alta qualidade de habilidades e desempenho.

Sistemas de trabalho de alto desempenho continuaram gerando interesse para os pesquisadores de gestão estratégica de RH. Por exemplo, Macky e Boxall (2008) examinaram a relação entre as HPWS e as atitudes dos funcionários. Eles descobriram que as práticas de RH associadas às HPWSs têm uma relação positiva e aditiva com as atitudes de satisfação do empregado no trabalho, confiança na administração, identificação psicológica com suas organizações e intenção de permanecer empregado em suas organizações. Esses pesquisadores avançaram na compreensão do que provavelmente media a relação entre os HPWs e o desempenho organizacional (Lengnick-Hall et al., 2009).

Ulrich (2004) alerta para a necessidade de haver equilíbrio entre processos e pessoas e também entre o operacional e o estratégico. A preocupação com o alinhamento entre as políticas de gestão de pessoas e os objetivos organizacionais também exerce uma pressão nas relações de poder, visto que tais objetivos só poderão ser alcançados se os aspectos relativos à qualidade de vida e ao bem-estar do trabalhador forem observados. $\mathrm{O}$ modelo estratégico exige que os profissionais da área de gestão de pessoas tenham uma formação mais ampla e crítica sobre os processos de trabalho e das organizações, pois exercem um papel importante na preparação dos demais gestores para assumirem uma posição mais ativa na coordenação de suas equipes de trabalho. Isso fortalece, assim, a ideia de que a gestão de pessoas não é responsabilidade exclusiva dos profissionais especializados, mas sim uma ação conjunta dos gestores de pessoas e os demais gestores da organização.

Fatores internos e externos podem influenciar a gestão estratégica de recursos humanos. Fischer (2002) explica que fatores internos são o produto ou serviço oferecido, a tecnologia adotada, a estratégia de organização do trabalho, a cultura e a estrutura organizacional. Os fatores externos podem ser classificados em duas categorias: de origem social e de origem no mercado. Os fatores de origem social são cultura de trabalho de dada sociedade e legislações trabalhistas e a intervenção de diferentes agentes, principalmente o Estado e instituições sindicais. Estes fatores exercem um papel mais restritivo, definindo os limites até aonde as organizações e seus gestores podem decidir nas configurações de suas políticas e práticas. Os fatores externos de origem no mercado definem o perfil de competências organizacionais necessárias para o negócio. Legge (2005) também afirma que 
os processos de mudança gerencial são moldados por fatores de contexto externo como os socioeconômicos, técnicos, legislações e mercado competitivo e fatores internos como cultura organizacional, estrutura, políticas, liderança, tecnologia e objetivos do negócio. Boxall e Purcell (2011) declaram que existe um ambiente do negócio, uma realidade externa que a empresa precisa lidar, como o ambiente político, econômico, social e tecnológico. Ulrich et al. (2013) acrescentam que as informações fora da empresa mudam o comportamento dentro da empresa. Os autores listam essas tendências contextuais como sendo sociedade, tecnologia, economia, política, meio ambiente e demografia. Quando a gestão de pessoas sabe organizar e tratar tais condições externas do negócio, o medo de um futuro incerto se transforma em confiança, pois os gestores de $\mathrm{RH}$ podem definir, prever e administrar suas reações (Ulrich et al., 2013). Portanto, fatores internos e externos determinam o desempenho que se espera das pessoas no trabalho e como será o modelo de gestão da organização (Fischer, 2002).

\subsubsection{Modelos de gestão de pessoas}

Modelos são abstrações que nos ajudam a compreender e a agir sobre a realidade (Fischer, 2001). Os modelos tratam de uma simplificação e uma abstração. Simplificação porque a complexidade do fenômeno real nunca pode ser retratada pelo modelo com total fidelidade e em outras dimensões. E abstração porque resultam sempre de uma representação, de uma explicação a respeito do fenômeno real (Astivera, 1982 citado por Fischer, 2001).

Souza e Peixoto (2013) também reforçam que os modelos em Ciências Sociais são considerados ferramentas ou instrumentos do conhecimento, que servem para analisar e compreender melhor a realidade que desejamos conhecer. Assim, os modelos de gestão representam um conjunto de características centrais que envolve as formas de estruturação, organização e funcionamento das organizações. As características abstraídas da realidade concreta são sintetizadas de forma a simplificar o entendimento de tal realidade.

Toda e qualquer organização depende, em maior ou menor grau, do desempenho humano para o seu sucesso. Assim, para diferentes contextos históricos ou setoriais, são encontradas diferentes modalidades de gestão. O que distingue um modelo de outro são as características dos elementos que os compõem e sua capacidade de interferir na vida organizacional, dando-lhe identidade própria (Fischer, 2002). 
O modelo de gestão de pessoas é a maneira de compreender como uma organização se estrutura e se organiza para gerenciar o comportamento humano no contexto do trabalho (Fischer, 2002). A estrutura ou modelo organizacional determina as características do modelo de gestão de pessoas dominante na empresa. Uma estrutura departamental orientada para a cadeia de comando e controle implica um modelo segmentado e restritivo. No entanto, uma estrutura matricial, por unidades de negócio ou em rede, demanda práticas de recursos humanos que percebam a empresa como uma totalidade. A empresa não tem como criar uma única função ou sistema capaz de orientar o comportamento humano no trabalho, mas pode propor um modelo, ou seja, um conjunto organizado de princípios, políticas, processos e procedimentos que contemplem suas expectativas sobre como esse comportamento deve ocorrer (Fischer, 2001).

O modelo de gestão de pessoas de uma empresa se estrutura definindo princípios, estratégias, políticas e práticas ou processos de gestão (Fischer, 2002). O autor explica três destes aspectos como sendo os componentes formais de um modelo de gestão de pessoas, os princípios, políticas e processos que interferem nas relações humanas no interior das organizações. Princípios são as orientações de valor e as crenças básicas que determinam o modelo e são adotadas pela empresa. Destaca-se o significado do homem e do trabalho definidos na cultura da empresa. As políticas estabelecem diretrizes de atuação com objetivos de médio e longo prazo para as relações organizacionais. Orientam e entregam os processos especificamente voltados para a gestão de pessoas. Os processos são os elementos mais visíveis do modelo, são as ações previamente determinadas, seguem os princípios de gestão e visam alcançar os objetivos traçados por políticas específicas. Exemplos de processos são planos de cargos, salários, capacitação e sucessão, administração de carreiras e as avaliações de desempenho. $\mathrm{O}$ autor integra mais um fator ao modelo de gestão que é o estilo de gestão dos gerentes de linha, aqueles que atuam diretamente com as equipes de trabalho. O gerente de linha é o gestor que estabelece limites ou estimula determinados padrões de comportamento. Sendo assim, podem contribuir ou não para a adequação da prática dos modelos adotados pela organização.

Os objetivos e parâmetros dos processos de gestão de pessoas classificam-se em: movimentação, desenvolvimento e valorização (Dutra et al., 2017). Os processos de apoio compreendem interações não ligadas unicamente à gestão de pessoas, mas que são fundamentais para que ela possa ser efetiva ou que tendem a influenciá-la fortemente: informações, comunicação, relações sindicais e relações com a comunidade. Fischer (2001) acrescenta, aos processos de engenharia que interferem nas formas de organização do 
trabalho, os programas de qualidade total e os processos de planejamento estratégico compartilhado. Porém, as intervenções dirigidas para orientar o comportamento organizacional também estão presentes, como sistemas de remuneração, gestão de carreiras, avaliação de desempenho, captação e demissão de pessoas.

Assim como descrevem Gondim, Souza, e Peixoto (2013), o modelo de gestão de pessoas define como selecionar, treinar, desenvolver, valorizar os trabalhadores, orientar carreiras, recompensar, remunerar, avaliar, promover, garantir o bem-estar e a qualidade de vida e também preparar para a aposentadoria e o desligamento. Os autores sintetizam que o modelo de gestão de pessoas organiza a vida no trabalho e zela pelo melhor equilíbrio entre os interesses da organização e as outras esferas da vida pessoal do trabalhador, tais como lazer, família, religião, política e vida social.

Os elementos que compõem o modelo de gestão de pessoas vão muito além da estrutura, dos instrumentos e das práticas normatizadas de RH. Eles abrangem tudo aquilo que interfere de maneira significativa nas relações entre indivíduos e a organização, tais como os procedimentos que a empresa adota para envolver os funcionários com suas definições estratégicas, a maneira pela qual ela estimula determinado tipo de relação com os clientes ou a imagem que ela passa internamente sobre seus produtos, equipamentos utilizados, desenvolvimento tecnológico e sobre outros temas organizacionais de relevância (Fischer, 2001).

Os tipos de modelos de gestão de pessoas podem variar na literatura. Apresentaremos a seguir diferentes autores e como estes classificam os modelos. Arthur (1992) foi um dos primeiros autores a desenvolver uma classificação de modelos de gestão de pessoas que denominou de sistemas de recursos humanos. Agrupou estes sistemas em duas categorias denominadas redutoras de custos e maximizador de comprometimento. Em 1994, o mesmo autor renomeou esta classificação para sistema de controle e sistema de comprometimento. O objetivo do sistema de controle de recursos humanos é reduzir custos diretos de mão de obra, melhorar a eficiência, priorizar o cumprimento de regras pelos funcionários e basear as recompensas aos empregados em critérios de produção mensuráveis. O sistema de comprometimento tem como propósito moldar os comportamentos e atitudes desejados, associando as metas dos funcionários e da organização.

Lepak e Snell (1999) propuseram uma tipologia de múltiplos sistemas de RH baseados em duas dimensões: singularidade do capital humano (especificidade firme das competências) e valor do capital humano (importância estratégica das competências) Definem quatro modelos ou configurações de gestão de pessoas: baseado no 
comprometimento, baseado no mercado, baseado na conformidade e baseado na colaboração. Este modelo teórico aponta para a forma como as empresas podem gerenciar estrategicamente o capital humano. O modelo baseado no comprometimento prioriza o envolvimento do empregado e em maximizar o retorno financeiro da empresa em investimentos no capital humano. $\mathrm{O}$ foco deste modelo está no desenvolvimento interno dos funcionários e alta produtividade. Já o modelo baseado no mercado tem o foco na contratação de pessoas qualificadas, no treinamento em tarefas na empresa, na vida longa na empresa de acordo com a produtividade e o incentivo centrados em metas. O modelo baseado na conformidade tem seu foco nas tarefas realizadas e treinamentos voltados para os procedimentos e práticas. $\mathrm{O}$ modelo baseado em colaboração prioriza a transferência de informações, treinamentos baseados no fortalecimento das alianças e relações.

Figura 3 Modelo teórico sobre as configurações de RH 


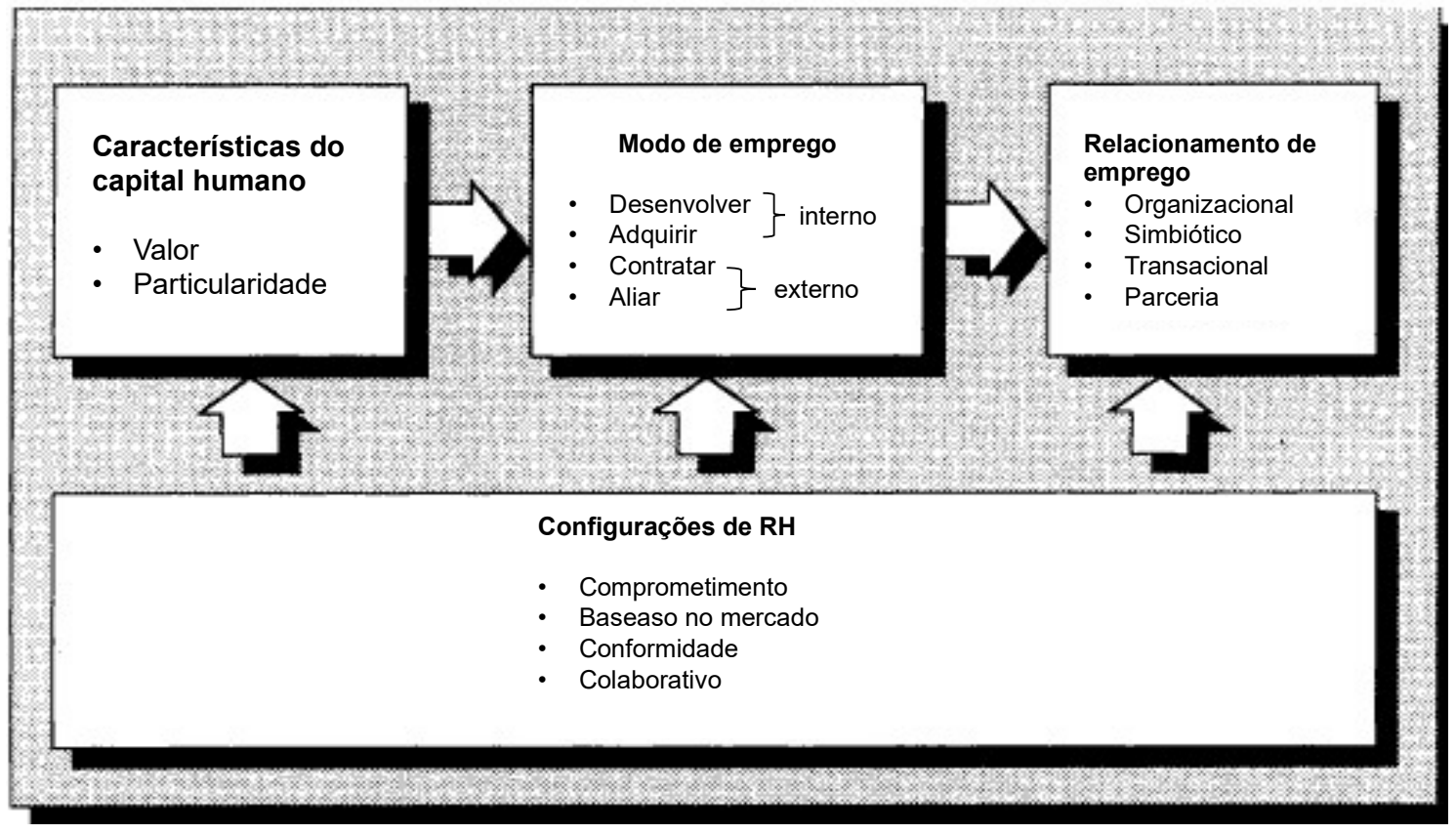

Fonte: Adaptado de Lepak e Snell (1999).

Figura 4 Arquiteturas de $\mathrm{RH}$

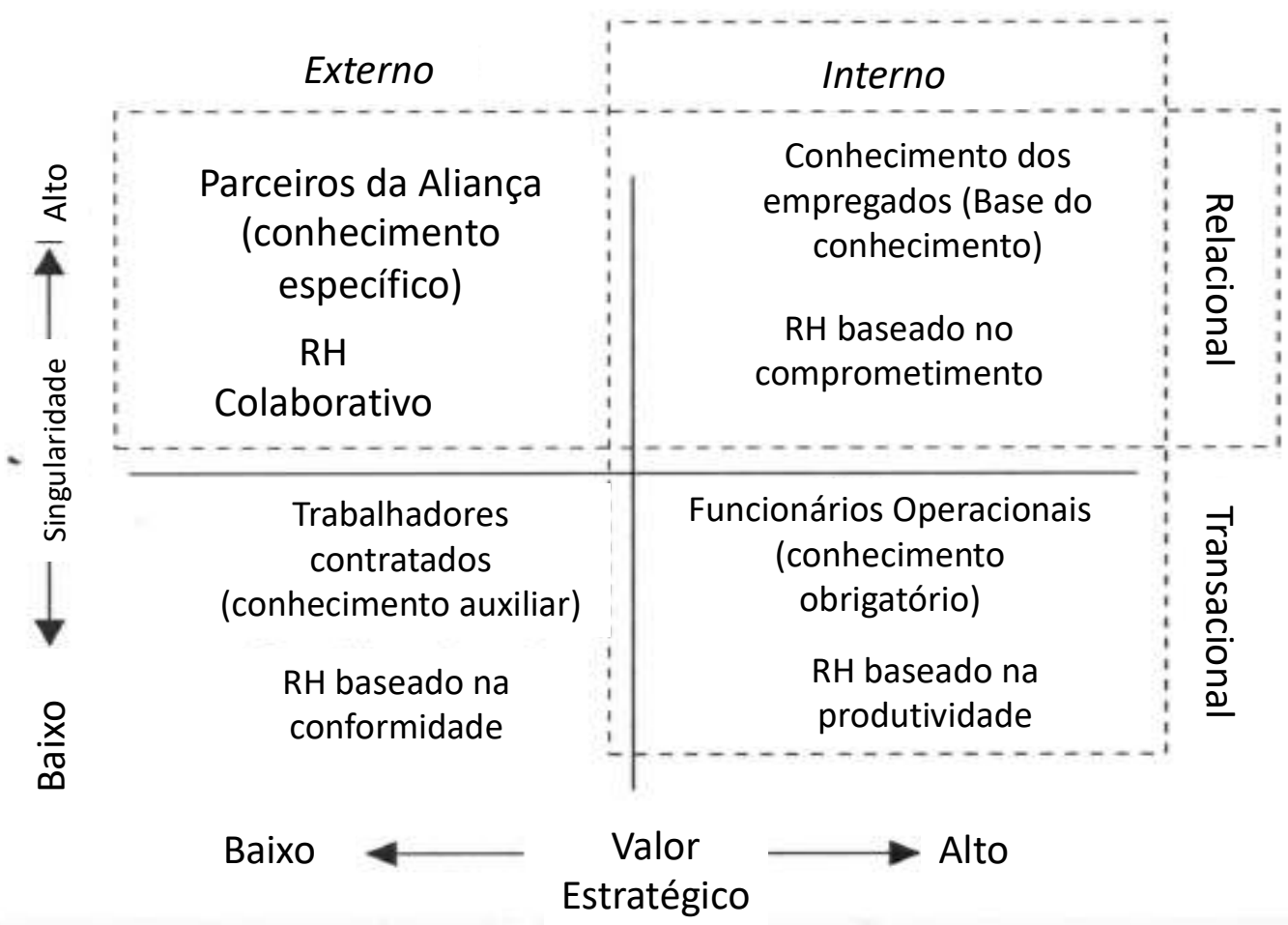

Fonte: Adaptado de Lepak e Snell (1999).

De acordo com Gondim et al. (2013), na literatura encontramos três grandes modelos de gestão de pessoas: o instrumental, o político e o estratégico. Apesar de serem apresentados 
em separado, na prática, eles se influenciam mutuamente, porque possuem elementos de práticas de RH que se complementam, dependendo dos valores da organização, do setor de atuação e das concepções de pessoas que atuam na área de gestão.

O modelo de gestão instrumental alinha-se com as ideias clássicas da teoria organizacional e utiliza conceitos de identidade de interesses, incentivos monetários, racionalidade e maximização dos resultados econômicos (Motta \& Vasconcelos, 2002). A relação deste modelo com gestão de pessoas é a busca da eficiência econômica da organização, desta forma, ele assume o papel de definir políticas, objetivos e ações necessárias para responder de forma mais adequada às estratégias da organização. Conforme os autores, apesar das críticas a este modelo, ele trouxe contribuições significativas para a área de gestão de pessoas como a análise de cargos, procedimentos de seleção, treinamento e qualificação. O modelo político caracteriza-se pela valorização do conflito entre as pessoas e com a organização como uma ação fundamental para o processo de gestão, ao contrário do modelo instrumental apresentado anteriormente. O papel da área de gestão de pessoas está relacionado à definição de políticas e práticas consideradas negociáveis ou contingenciais, buscando um equilíbrio entre interesses diversificados (Gondim, Souza e Peixoto, 2013). O modelo estratégico aparece em um contexto marcado por transformações no mundo das organizações e dos processos de trabalho. A competitividade acentuada pela globalização do trabalho, a importância da inovação para se conseguir sustentar no mercado e as transformações são fatores que impulsionaram as empresas a adotarem novas formas de gerenciar pessoas. A principal meta deste modelo é alinhar as funções e práticas da área de gestão de pessoas aos objetivos estratégicos da organização.

Fischer, em 2002, classificou os modelos de gestão de pessoas em quatro categorias, sendo modelo de gestão de pessoas como departamento pessoal, como gestão do comportamento, como gestão estratégica e como vantagem competitiva. $\mathrm{O}$ autor retomou esta definição em Fischer (2015), porém alterando a denominação de departamento pessoal para clássico, gestão do comportamento para motivacional e vantagem competitiva para competitivo.

O modelo de gestão de pessoas como departamento pessoal é um conceito que reflete a imagem de uma área de trabalho voltada prioritariamente para as transações processuais e os trâmites burocráticos com o objetivo de atingir o máximo de eficiência do trabalhador. Produtividade, recompensa e eficiências de custo eram os conceitos articuladores deste tipo de modelo. O modelo como gestão do comportamento humano aplica a psicologia para apoiar a compreensão e a intervenção na ação da gestão de recursos humanos. Criaram-se 
instrumentos e métodos de avaliação e desenvolvimento de pessoas. Descobriu-se a importância do gerente de linha na relação entre a empresa e as pessoas, e, assim, ele constituiu a principal preocupação da gestão de recursos humanos. O foco deste modelo é resumido em treinamento gerencial, as relações interpessoais, os processos de avaliação de desemprenho e o estímulo ao desenvolvimento de perfis gerencias coerentes com o processo de gestão de pessoas desejado pela empresa. Motivação e liderança são conceitos centrais para este modelo. O modelo estratégico de gestão de pessoas, segundo Fischer (2002), apareceu nas décadas de 1970 e 1980. Os planos estratégicos dos vários processos de gestão de recursos humanos são derivados das estratégias coorporativas das empresas. Nesse momento, apontou-se uma separação entre o modelo estratégico de pessoas e o modelo comportamental. Indivíduos motivados e bem atendidos das suas necessidades estão prontos para atuar, porém, isto não significa nada para as diretrizes estratégicas da organização. A principal responsabilidade da gestão de recursos humanos é integrar os fatores externos, os fatores internos, os interesses dos stakeholders (acionistas, gerentes, grupos de empregados, sindicatos, comunidade e governo) e pressões situacionais entre si e com a estratégia corporativa da empresa (Staehle, 1990 citado por Fisher, 2002).

O quarto modelo de gestão de pessoas apresentado por Fischer (2002) é o modelo competitivo articulado por competências. Esta nova definição tem origem nas novas mudanças de mercado surgidos na década de 80, como estratégia competitiva, vantagem competitiva, reengenharia e reestruturação, competências essenciais e reinvenção do setor. As questões da estratégia e da competitividade readquiriram importância como dimensões essenciais da gestão empresarial. A principal tarefa do modelo competitivo de gestão de pessoas seria desenvolver e estimular as competências humanas necessárias para que as competências organizacionais se viabilizem.

Tabela 1 Modelos de gestão de pessoas.

\begin{tabular}{lll}
\hline \multicolumn{1}{c}{ Autores } & \multicolumn{1}{c}{ Classificações } & \multicolumn{1}{c}{ Características } \\
\hline Arthur (1992) & Sistema de controle & Redução de custos, eficiência, \\
& regras e recompensas. \\
& Sistema de comprometimento & Moldar comportamento e \\
& associar metas dos funcionários \\
& às da organização \\
\hline
\end{tabular}




\begin{tabular}{|c|c|c|}
\hline \multirow[t]{5}{*}{ Lepak e Snell (1999) } & Comprometimento & Desenvolvimento do capital \\
\hline & & humano e alta produtividade. \\
\hline & Mercado & $\begin{array}{l}\text { Pessoas já qualificadas, } \\
\text { treinamento de tarefas, } \\
\text { produtividade e incentivos } \\
\text { centrados em metas. }\end{array}$ \\
\hline & Conformidade & $\begin{array}{l}\text { Foco nas tarefas e treinamentos } \\
\text { voltados aos procedimentos e } \\
\text { práticas. }\end{array}$ \\
\hline & Colaboração & $\begin{array}{l}\text { Transferências de informações, } \\
\text { treinamentos voltados para } \\
\text { fortalecimento das alianças e } \\
\text { relações. }\end{array}$ \\
\hline \multirow[t]{4}{*}{ Fischer $(2001,2002,2015)$} & Clássico & $\begin{array}{l}\text { Transações processuais, } \\
\text { produtividade, recompensa e } \\
\text { custos. }\end{array}$ \\
\hline & Motivacional & $\begin{array}{l}\text { Motivação para atingir objetivos } \\
\text { da organização. Avaliação, } \\
\text { desenvolvimento, treinamento } \\
\text { gerencial e relações } \\
\text { interpessoais. }\end{array}$ \\
\hline & Estratégico & $\begin{array}{l}\text { Alinhar estratégia de RH com a } \\
\text { estratégia da organização. } \\
\text { Integrar fatores internos e } \\
\text { externos. }\end{array}$ \\
\hline & Competitivo & $\begin{array}{l}\text { Estratégia, competividade e } \\
\text { competências essenciais. }\end{array}$ \\
\hline \multirow[t]{3}{*}{ Gondim et al. (2013) } & Instrumental & $\begin{array}{l}\text { Políticas visando a eficiência } \\
\text { econômica da organização, evitar } \\
\text { conflitos, decisões verticais. }\end{array}$ \\
\hline & Político & $\begin{array}{l}\text { Valorização do conflito, } \\
\text { negociação, equilíbrio de } \\
\text { interesses entre organização e } \\
\text { funcionários. }\end{array}$ \\
\hline & Estratégico & $\begin{array}{l}\text { Alinhar políticas e práticas de } \\
\text { RH à estratégia da organização, } \\
\text { qualidade de vida, gestão de } \\
\text { pessoas realizada por todos os } \\
\text { gestores da organização. }\end{array}$ \\
\hline
\end{tabular}

Fonte: Elaboração da autora. 
As quatro propostas de modelos de recursos humanos apresentadas neste trabalho podem ser diferenciadas pelo tempo em que foram formuladas e a presença, ou não, da discussão sobre estratégia em RH. A classificação de Arthur (1992) não discute ainda a questão da estratégia na atuação do RH. Lepak e Snell (1999) inicia esta conversa identificando modelos com mais ou menos características estratégicas, conforme Figura 4. Gondim et al (2013) e Fischer (2015) destacam em suas classificações o aspecto estratégico de $\mathrm{RH}$, diferenciando dos outros modelos caracterizados pelos autores. Assim, verificamos que, ao longo do tempo, a estratégia em RH foi sendo cada vez mais discutida a ponto de se tornar uma caracterização de modelo utilizado pelas organizações e uma maneira mais contemporânea de se gerir a área de recursos humanos.

A gestão de RH deve buscar a melhor configuração de políticas e práticas no uso da mão de obra dentro da organização (Amorim, 2015). O autor complementa que o trabalho e as relações de trabalho precisam de uma abordagem que facilite a compreensão dos diversos fatores que influenciam interna e externamente as organizações. As variações no ambiente externo e interno das empresas resultam em diferentes configurações de relações de trabalho e de RH.

\subsubsection{Relações de trabalho}

$\mathrm{O}$ vínculo entre gestão estratégica de $\mathrm{RH}$ e relações de trabalho demonstra ser significativo. Os estudos sobre gestão estratégica de recursos humanos concluem que as empresas são capazes de implementar a gestão de recursos humanos e atingir as metas corporativas, na medida em que eles alistam a cooperação de outras partes interessadas capazes de ajudar ou impedir, incluindo componentes internos, como funcionários, e componentes externos, como comunidades, sindicatos e governos (Kaufman, 2015). O autor complementa que as relações de trabalho demonstram ser uma visão de ganho mútuo entre organizações e sindicatos, onde os interesses são inevitavelmente divergentes, porém bons gestores, às vezes com a participação dos sindicatos e em outros momentos sem eles, operam em um nível estratégico e tático para alinhar, equilibrar e integrar esses interesses.

O campo de estudos das relações de trabalho, na tradição norte-americana de industrial relations, tem seu início associado à intensificação dos conflitos entre o capital e o trabalho na passagem do século XIX para o século XX (Horn, 2011). Nos Estados Unidos, tornou-se objeto de uma abordagem específica, a do industrial relation, como resultado da 
confluência de dois grupos distintos, o dos acadêmicos simpatizantes dos sindicatos dos trabalhadores e o dos empregados progressistas que buscavam soluções para os conflitos trabalhistas. Tinham como fundamento que a força de trabalho é uma mercadoria especial e não um produto comum, indissociável da pessoa humana.

As relações de trabalho consistem em um complexo de relações entre a administração de empresas, os trabalhadores e as agências governamentais (Dunlop, 1993). O mesmo autor descreve o sistema de relações de trabalho (SRT) como uma rede de normas que governam as relações de trabalho, determinada por atores específicos, interagindo sob certos contextos que não controlam de imediato, e que compartilham em ideias em comum como reguladores. Portanto, a estrutura do SRT compreende a rede de normas e três outros elementos: os atores, o contexto e a ideologia do sistema. Os atores de um sistema de relações de trabalho (SRT) são as pessoas que constituem as hierarquias dos administradores, dos trabalhadores e das agências especializadas governamentais e privadas (Horn, 2011). O autor define que a hierarquia dos administradores é composta pelas pessoas que decidem sobre as relações de trabalho em nome da organização. A hierarquia dos trabalhadores envolve tanto as composições formais, como conselhos de trabalhadores em uma empresa, sindicatos e partidos políticos, quanto arranjos informais, consequência da convivência entre trabalhadores por períodos mais longos. Por último, o terceiro ator do sistema são as agências especializadas nos assuntos sobre relações de trabalho, sendo elas privadas ou públicas, como órgãos governamentais, ministério ou departamento do trabalho, e o sistema judicial.

A proeminência de algum ator no processo de regulação pode caracterizar os sistemas nacionais de relação de trabalho. Horn (2011) descreve três modelos básicos baseados no trabalho de Dunlop (1993): sistemas estatutários, quando o regulador principal é o Estado; sistemas de negociações coletivas, quando a regulação conjunta entre a representação de empregados e a de trabalhadores exerce o papel mais importante; e sistemas de regulação unilateral pelos empregadores, quando o poder irrestrito dos empregadores pode ser exercido sem constrição da lei estatal ou de acordos coletivos.

Os contextos são decisivos para moldar as regras estabelecidas pelos atores nos sistemas de relações de trabalho (Dunlop, 1993). De acordo com Horn (2011), existem três contextos mais relevantes: contexto dos mercados ou restrições orçamentárias, contexto tecnológico e contexto da distribuição do poder na sociedade. Cada um deles exerce sua influência sobre certos pontos do sistema. O contexto dos mercados ou da restrição orçamentária pode agir sobre a hierarquia dos administradores, o contexto tecnológico afeta a forma de organização dos administradores e trabalhadores, e, por fim, a distribuição do 
poder na sociedade influi no prestígio na posição dos atores em seu papel de formuladores de regras (Dunlop, 1993). A combinação dos tipos puros em híbridos são as que melhor expressam os casos reais de sistemas nacionais de relação de trabalho.

A ideologia de um SRT significa um conjunto de ideias compartilhado pelos atores sobre o lugar e papel de si mesmos e dos demais atores no processo de regulação (Horn, 2011). Cada ator pode possuir sua própria ideologia ou escala de valores, portanto deve-se haver um consenso para haver estabilidade no sistema.

Horn (2011) afirma também que a sociedade industrial criou trabalhadores assalariados e administradores dos processos de produção e trabalho, e não existe sociedade industrial sem normatização das relações entre esses dois atores. As normas que conduzem as relações de trabalho compreendem três tipos de regras: os procedimentos para fixação das regras, as normas substantivas e os procedimentos para aplicação das normas substantivas a situações particulares (Dunlop, 1993).

Segundo Horn (2011), são classificadas como regras substantivas aquelas que regulam diretamente a relação de emprego, como a jornada de trabalho. As normas de procedimento regulam indiretamente esta relação ao definir critérios sobre a formulação, interpretação e eficácia das normas substantivas. As normas que regulam as relações de trabalho podem assumir várias formas de expressão, compreendendo regras formais do Estado, como leis e decretos; acordos de negociação coletiva do trabalho; políticas e regulamentos empresariais para a gestão de pessoas; decisões de órgãos privados de arbitragem de conflitos trabalhistas; regulamentos de sindicatos e de associações empresariais; e regras informais derivadas de costumes e cultura no local de trabalho.

A perspectiva de Dunlop (1993) é criticada pela perspectiva da escolha estratégica de Kochan et al (1986) citado por (Nogueira, 2008). Esta proposição compõe as relações de trabalho com três fatores: atores em relação, estruturas de negociação coletiva e o local de trabalho ou divisão técnica do trabalho. Os atores em relação compreendem os trabalhadores, a gerência e o governo e suas escolhas estratégicas. A escolha estratégica dos agentes é a definidora das relações e esse processo tende à descentralização, devido às diferenças de cada local de trabalho e suas particularidades políticas, e de recursos humanos. No entanto, a negociação coletiva burocrática e hierárquica fica em segundo plano (Nogueira, 2008). Por sua vez, Amorim (2007) defende que o sistema de relações de trabalho oferece elementos para análise do contexto, dos seus atores, das instituições e das suas regras de funcionamento, e as mudanças dessas regras também. 
Pastore e Zylberstajn (1988, p.19) afirmam que "todo sistema de relações do trabalho administra o conflito através de um conjunto de procedimentos". Os autores estabelecem dois tipos de sistemas: o estatutário e o negocial. Os sistemas estatutários são aqueles que definem as regras no corpo da lei e os sistemas negociais são aqueles que estabelecem as regras através dos contratos resultantes da negociação direta entre as partes. No mundo industrializado, existe o privilégio da utilização de um dos modelos, porém não existe um sistema totalmente estatutário e nem completamente negocial. No Brasil, o sistema de relações de trabalho está estabelecido na legislação, assim como no conjunto de procedimentos voluntários entre os sindicatos, as associações e os grupos de trabalhadores e empresários (Pastore \& Zylberstajn, 1988). Entretanto, o sistema brasileiro possui um quadro legal que deixou pouca autonomia para as partes negociarem efetivamente.

Nogueira (2008) identifica quatro correntes sobre o sistema de relações de trabalho: as correntes institucionalistas de Dunlop (1993), as correntes do personnel management e comportamento organizacional, as correntes da escolha estratégica e as correntes marxistas. As correntes institucionalistas apresentam o conflito como inerente às relações de trabalho, porém podendo ser regulado e administrado pelas negociações coletivas. As correntes do personnel management e comportamento organizacional buscam diluir o conflito e tendem a individualizar o problema. As correntes da escolha estratégica apontam para a definição de que o sistema depende da ação dos atores. E, por fim, as correntes marxistas entendem o conflito como inevitável e antagônico enquanto existir o sistema capitalista (Nogueira, 2008).

A principal norma legislativa brasileira, reguladora dos direitos do trabalho, é a Consolidação das Leis de Trabalho (CLT). A CLT regulamentou os direitos dos trabalhadores e estabeleceu normas sobre a criação, o funcionamento e a estrutura das entidades sindicais, determinou também sua regulação pelo Ministério do Trabalho (Amorim, 2015). Com relação às negociações coletivas, o mesmo autor as define como sendo "um processo de interação verbal em que as partes dialogam para propor e argumentar" (p.54). Quando a negociação falha ou não se torna uma alternativa, uma consequência que aparece é o conflito. A definição de conflito é tudo o que implique no uso da força ou da ameaça de seu uso para obrigar a outra parte à decisão (Jder, 1985 citado por Amorim, 2015). A influência dos sindicatos, para o autor, tem o sentido de poder de barganha dos trabalhadores nas relações de trabalho.

De acordo com Amorim (2015), as greves no Brasil tiveram três principais momentos. O primeiro momento foram os movimentos grevistas do início do século XX até 
1920 em São Paulo e outras grandes cidades que formavam o mercado de trabalho assalariado; o segundo momento foram as greves populistas, de 1950 a 1964; e um terceiro momento no período militar, pela quase ausência de movimentos grevistas devido à repressão política ao movimento sindical. De 1978 em diante, as greves voltaram a aparecer no mercado de trabalho, tendo como maior foco a perda salarial provocada pela inflação. No Brasil, Amorim (2015) descreve o contexto histórico e evolutivo das negociações coletivas que ocorreram de 1978 a 1985. Em 1978, com a abertura democrática e aumento de movimentos populares, elevação da inflação e aumento da indexação na economia, o movimento sindical retoma a função de interlocutor na sociedade. Aparece então a existência de um "novo sindicalismo" a partir da paralização de uma indústria automobilística em São Bernardo do Campo. Realizou-se uma negociação coletiva, na qual representantes das empresas e dos sindicatos se reuniram para definir um acordo, e esse fato se transformou em um marco das negociações coletivas. Nos meses seguintes, reinvindicações com greves foram realizadas por diversas categorias de trabalhadores, motivadas pelo sucesso desta paralização. Em 1982 ocorrem as eleições que empossam governadores oposicionistas e há elevação da dívida externa, momento em que ocorrem a criação das centrais sindicais. Entre 1981 e 1983 verifica-se uma recessão com alto índice de desemprego, e em 1985 ocorrem as eleições indiretas de um civil para assumir a presidência, neste contexto a negociação coletiva ganha importância. Em 1990, greves foram motivadas pelo descumprimento de direitos dos trabalhadores por parte das empresas. Neste período a restrição com relação às greves perdeu importância e o direito de greve se colocou como força de usos e costumes (Amorim, 2015), tanto que nos anos 2000 elas eram praticadas e pouco questionadas, ainda que continuem sendo momentos tensos nas relações de trabalho. O mesmo autor afirma que a evolução das negociações coletivas no Brasil permitiu às empresas e empregados um aprendizado nas negociações e nas resoluções dos conflitos.

O projeto de lei PL 6.787/2016, aprovado pela câmara dos Deputados em 26 de abril, modificou cerca de 200 dispositivos da CLT, além de rever pontos específicos de outras leis (DIEESE, 2017). Algumas destas alterações aparecem na regulamentação de novas formas de contratação como o trabalho intermitente e teletrabalho, pactuação de banco de horas, contrato individual, extinção da obrigatoriedade da homologação da rescisão no sindicato para contratos com mais de um ano de duração, contribuição sindical facultativa, dentre outras. Estas mudanças possuem críticas favoráveis e desfavoráveis. Para DIEESE (2017) este projeto de lei resultará na redução de direitos e desmantelamento do sistema de relações de trabalho, reduzindo o papel do Estado na proteção ao trabalhador. Porém, para CNI (2017) 
esta nova lei abre um horizonte de mais segurança jurídica e cooperação, melhorando o ambiente de negócios, contribuindo para o crescimento econômico, beneficiando empresas e empregados.

Diante da complexidade e importância dos construtos de gestão estratégica de RH e relações de trabalho para as empresas, verificou-se a relevância de identificar como se dá a gestão conjunta desses dois aspectos nas organizações deste setor. Este estudo tem como objetivos específicos a investigação do quanto estas empresas adotam políticas e práticas de gestão estratégica de RH, identificando e analisando as características específicas de relações de trabalho, e por fim relacionando as características das relações de trabalho com a adoção de práticas estratégicas de RH por estas organizações.

2.1.4 Estudos recentes sobre GERH e relações de trabalho: uma breve análise

Ulrich, Younger, e Brockbank (2008), discutem como o departamento de RH pode agregar valor baseados em duas premissas: organização de $\mathrm{RH}$ alinhada à estrutura do negócio, e cinco funções e responsabilidades do RH como centro de serviços, corporativos, centros de conhecimentos, RH integrado e RH operacional.

Figura 5 Visão geral da organização de RH.

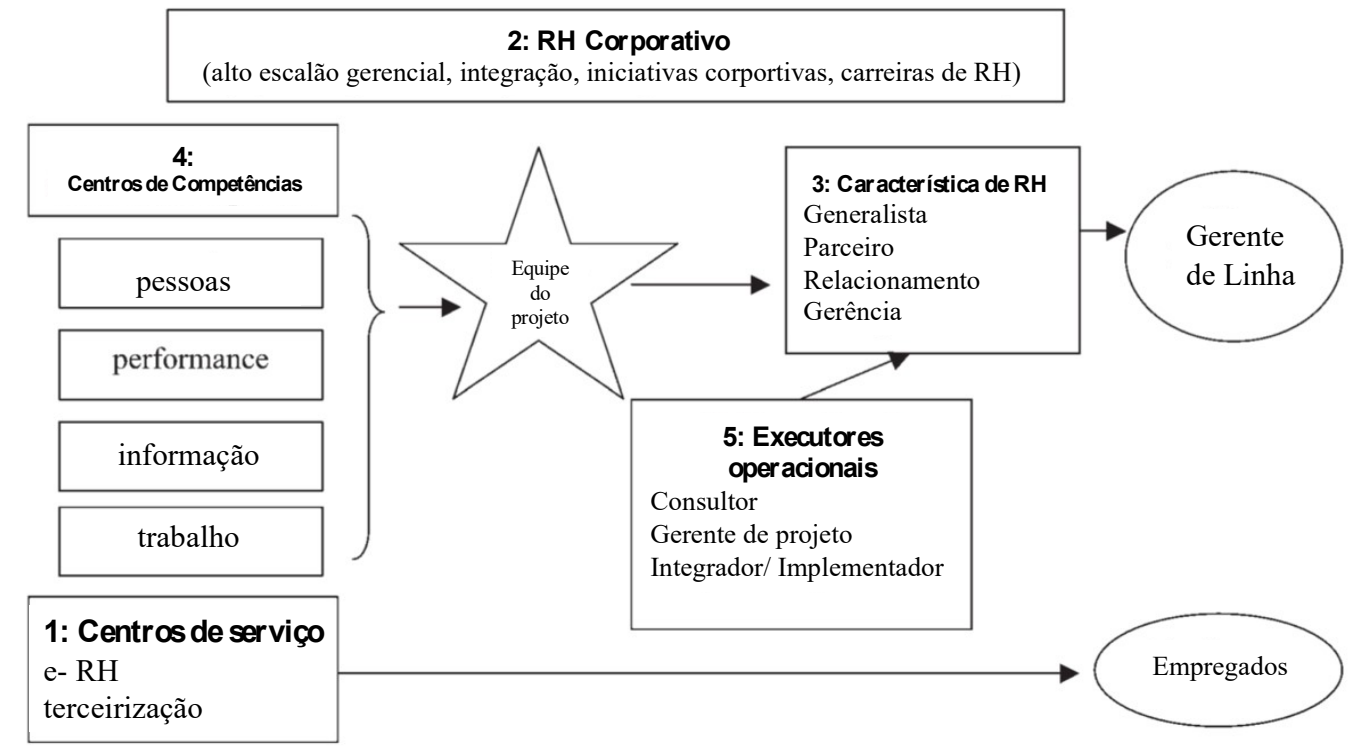

Fonte: Adaptado de Ulrich et al. (2008). 
Os autores demonstram organizações de $\mathrm{RH}$ de acordo com o tipo de negócio conforme apresentado na figura adiante.

Figura 6 Alinhamento entre a organização do negócio e a organização do RH.

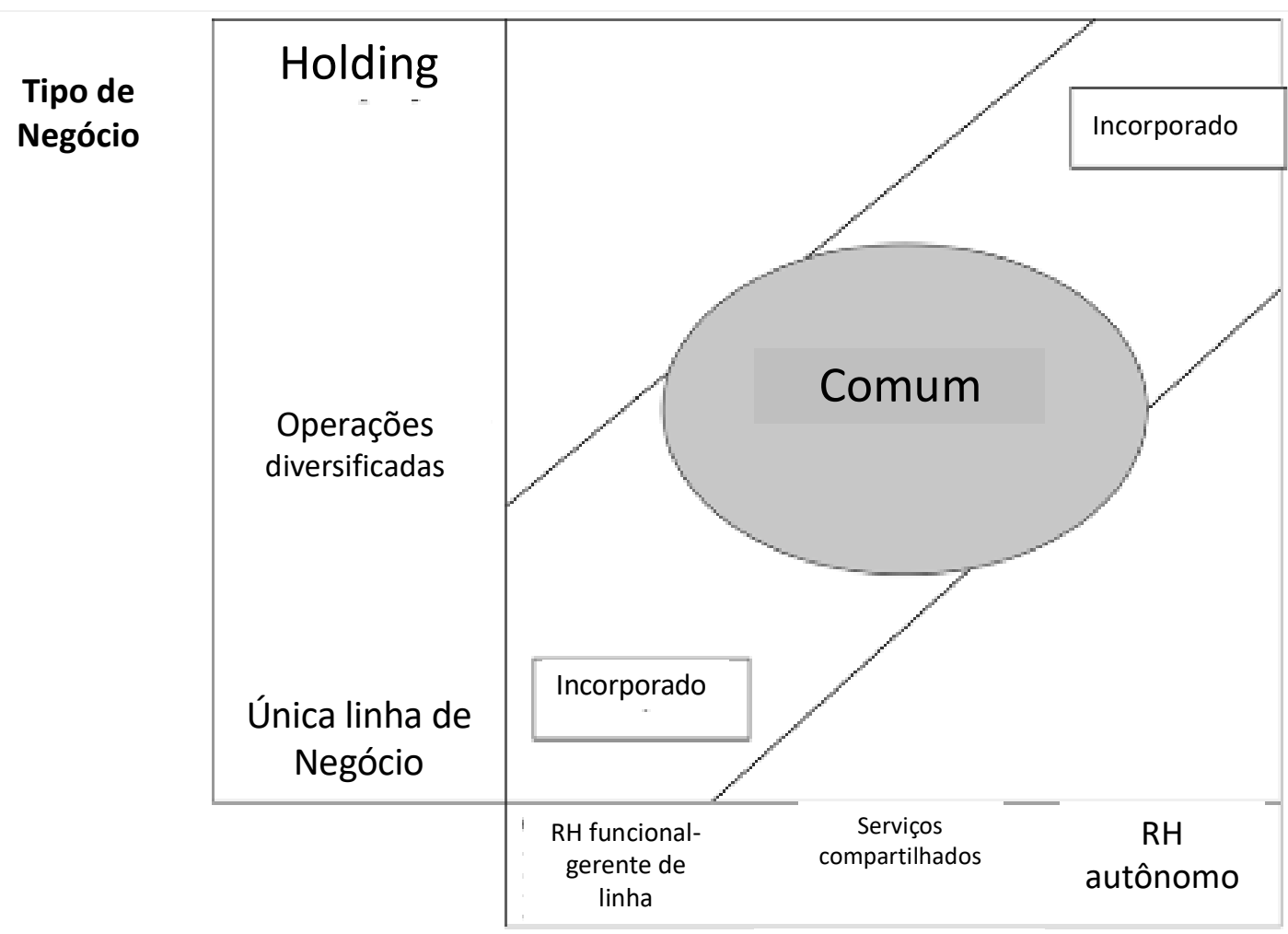

RH da organização

Fonte: Adaptado de Ulrich et al. (2008).

Pequenos negócios ou startups normalmente não possuem uma equipe de RH. Até que a empresa obtenha de 50 a 75 funcionários, um gerente de linha pode lidar com as atividades de RH básicas. Conforme a empresa cresce, a equipe de RH cresce também. Enquanto a organização possuir uma única linha de negócio, as políticas de RH serão para toda a empresa, não existindo uma diferenciação, e o RH participa de decisões relacionadas somente aos funcionários. Nas holdings, cada empresa possui suas práticas de RH autônomas com base nas necessidades da empresa, o RH está incorporado nos negócios.

Monks et al. (2012) realizaram uma pesquisa qualitativa com entrevistas com 56 trabalhadores do setor de tecnologia da informação e comunicação na Irlanda e Reino Unidos. O objetivo desta pesquisa foi identificar as reações dos funcionários a dois tipos diferentes de sistemas de RH. Identificaram o papel fundamental da filosofia de RH na operação do sistema desta mesma área. Os autores utilizam a definição de filosofia de RH como sendo os princípios orientadores que identificam e caracterizam o tratamento dos 
funcionários submetidos à um sistema de recursos humanos específico. Baseada no sistema de Lepak e Snell (2002), a pesquisa identificou que as organizações e os gerentes de RH têm dado pouca atenção ao papel que a filosofia adotada pode desempenhar na estrutura geral de um sistema de RH. A pesquisa revela o importante papel que o alinhamento do RH de sua filosofia e de seus processos desempenha no funcionamento dos sistemas de RH, nas escolhas que as empresas têm nas maneiras como configuram seus sistemas de RH e nos resultados que podem obter.

Kaufman (2015), analisa quatro livros que discutem GERH, dois pioneiros e dois mais recentes, Strategic Human Resource Management escrito por Fombrun, Tichy e Devanna em 1984; Managing Human Assets escrito por Beer, Spector, Lawrence, Mills, and Walton em 1984; Short introduction to strategic human resource management escrito por Cascio e Boudreau em 2012; e HRM \& performance: Achievements \& challenges escrito por Paauwe, Guest, Wright em 2013. A revisão encontra áreas de constância e áreas de mudanças sobre o assunto estudado. A definição e o domínio da GERH permanecem os mesmos: escolhas, alinhamento e integração do sistema de RH de uma organização e o capital humano contribuem para os objetivos estratégicos do negócio. O campo de conhecimento de GERH também evoluiu nos últimos 30 anos, está mais bem organizado e focado na relação RH e performance, na adequação da diferenciação de capital humano existente, na alta participação do sistema de RH e demonstra maior ênfase em posicionar as funções de RH como um participante estratégico. Menor foco dos estudos estão nas condições macroeconômicas e tecnologia da produção, os desafios das mudanças organizacionais e líderes transformacionais, sindicatos e relações de emprego. O autor conclui que as pesquisas em GERH têm avançado em conhecimento útil através do uso das teorias com métodos empíricos, e também recomenda estudos em setores menos inspiradores como call centers e hotéis, e atentar-se para as lições de aprendizado de casos de insucesso.

Cascio (2015) discute o artigo publicado por Kaufman (2015) do ponto de vista da relevância de estudos em GERH. Segundo o autor, Kaufman divide sua análise em duas áreas distintas, público-alvo (acadêmicos e gerentes gerais versus pesquisadores) e orientação do estudo (observador de campo e métodos de observação participante versus cientista "cientistas de torre de marfim"). O destaque excessivo neste último, "cientistas de torre de marfim", são estudos relevantes somente para acadêmicos e não são usados por organizações. O autor defende que o rigor e a disciplina científicas são importantes, porém os estudos devem ser relevantes para a sociedade também. Devem influenciar o pensamento acadêmico e criar conceitos, além de alterar a forma como os gerentes estabelecem suas 
prioridades e tomam decisões. $\mathrm{O}$ autor orienta que os pesquisadores devem trabalhar diretamente com os gerentes, criando modelos que envolvem os fatores internos e externos, ajudando na definição das estratégias de negócio e RH.

Schmidt, Pohler, e Willness (2018) procuraram compreender se as empresas aplicam diferentes sistemas de gestão de RH para diferentes ocupações (high performance work system - HPWS) e como esta prática influencia os resultados da empresa e dos funcionários. Realizaram-se dois estudos, o primeiro coletou os dados de gestores e os resultados sugerem que as empresas diferenciam seus investimentos em RH de acordo com o valor estratégico das ocupações. A diferenciação do capital humano foi associada positivamente ao desempenho da empresa. O segundo estudo baseou-se em dados obtidos de funcionários não gerentes. Os resultados indicaram que os funcionários que recebiam menos investimentos eram menos imparciais, maior intensão de rotatividade e menos cidadania organizacional. Obteve-se evidências de benefícios para a organização quando utilizados os sistemas de diferenciação de RH, entretanto, sugere-se considerar como equilibrar os efeitos no desempenho da empresa e no bem-estar dos funcionários.

Litwin e Eaton (2018) discutem sobre a participação formal e informal dos trabalhadores nas decisões da organização e o desempenho organizacional. Buscaram determinar se esses dois tipos de participação se complementam ou prejudicam umas às outras, e encontraram evidências para a segunda opção. Por estruturas formais os autores entendem os sindicatos, conselhos de trabalhadores, comitês de segurança de fábricas e etc. Por relações informais, os autores definem como as relações do dia-a-dia entre supervisores e subordinados, nas quais os subordinados são autorizados a participar de decisões de trabalho. A pesquisa foi realizada no setor da saúde, em 16 hospitais. As estruturas formais pareciam ajudar os departamentos menos participativos a melhorar seu desempenho. No entanto, essas mesmas estruturas também pareciam impedir os departamentos com altos níveis de participação informal. Embora com cautela com relação à generalização, o caso serve como um alerta para aqueles que buscam instituir a participação em um ambiente no qual alguns trabalhadores há muito sentem que têm a autoridade, influência e informações necessárias para realizar seu trabalho de maneira eficaz. Estatisticamente, a participação formal no desempenho é positiva. Portanto, os autores sugerem que se a participação formal e informal trabalhasse em conjunto poderiam complementar o impacto benéfico um do outro.

Harpaz e Meshoulam (2010) trata em seu estudo do significado do trabalho, relações de emprego e gestão estratégica de pessoas em Israel. Quanto ao significado do trabalho, o autor observa que os trabalhadores israelenses estão mais materialistas e individuais. As 
negociações coletivas em Israel aparecem da forma tripartida entre empregados, empregadores e estado. Uma mudança na lei em Israel em 1995, que proibiu os sindicatos de oferecer planos de saúde, reduziu as taxas de sindicalização de $80 \%$ para $25 \%$ da força de trabalho. O estado e os sindicatos estão envolvidos em diversos conflitos e o governo têm se posicionado de forma a diminuir as ações dos sindicatos. As negociações coletivas são predominantes entre os trabalhadores e os empregadores. Esta estrutura trouxe segurança ao trabalhador e melhorou as condições de trabalho, porém possibilitou ampla flexibilidade aos empregadores de deslocar os empregados de um trabalho para outro. A transição do RH tradicional para uma GERH não aparece na maioria das empresas israelenses.

Gould e Desjardins (2012) estudam a relação de emprego do ponto de vista da cooperação e dos conflitos. Segundo os autores, teorias surgiram com o objetivo de conciliar os interesses entre capital e trabalho, contudo, as tentativas de relacionar o tempo na mudança da proporção do conflito para a cooperação na relação de emprego, não foram suficientes. O estudo apresenta uma visão estabelecendo o tempo como uma variável independente e a taxa de mudança de conflito para cooperação como uma variável dependente. $\mathrm{O}$ artigo apresenta uma teoria sobre esta questão em seis princípios. $\mathrm{O}$ primeiro demonstra que elementos que geram conflitos podem existir de curto e longo prazo, como o piso salarial que está sempre presente nestas discussões. O segundo afirma que os elementos que criam cooperação entre capital e trabalho existem apenas a longo prazo, como negociações de concessões entre sindicatos e empregadores aos funcionários que se comprometem a permanecer com seu empregador a longo prazo. O terceiro aspecto é o surgimento de novas formas de emprego, nas quais a força de trabalho transfere afiliações à medida que se deslocam entre empregos de curta duração, tornando as relações de trabalho entre um grupo de empregadores e o empregado. O quarto aspecto é que as definições de longo e curto prazo variam com o tipo de emprego. O quinto determina que para uma relação de emprego as definições de curto e longo prazo são acordadas por cada parte. O sexto ponto demonstra que o alinhamento dos interesses do empregador e do empregado exige que as partes façam um investimento quando ainda estão na fase de curto prazo do seu relacionamento. Os seis princípios sugerem que a relação de emprego é mais afetada pelo conflito do que pela cooperação, quando a relação está na fase de curto prazo da sua existência. O estudo possui aplicação teórica e prática, auxiliando na compreensão das consequências estratégicas de novas formas de emprego. Conclui que a relação entre conflito e cooperação e entre capital e trabalho pode mudar em meses ou anos, quando outros fatores 
são mantidos constantes, de acordo com o tempo de relacionamento entre empregado e empregador.

A pesquisa de Vernon e Brewster (2013) demonstra uma análise sistemática das implicações estruturais do sindicalismo para a integração estratégica das funções de RH, que varia internacionalmente. Implantando dados de pesquisas em mais de 3.000 organizações em mais de 30 países, a pesquisa conclui que o sindicalismo facilita a integração estratégica das funções de RH, porém também constatou que a influência do nível de organização do sindicalismo sobre a integração estratégica do RH depende de aspectos do padrão nacional das relações industriais. O resultado inverso somente apareceu na Grécia e no Nepal, países com características particulares, como antagonismo de classe, pouco apoio estatutário para o sindicalismo e extrema política de polarização.

Costa (2007) compara em seu estudo os elementos institucionais e políticos centrais dos sistemas de relações de trabalho entre Brasil e Canadá e as mudanças nos regimes de emprego e estrutura do mercado de trabalho nestes países. A pesquisa demonstra que a flexibilização do trabalho em ambos os países resultou em redução de direitos, aumentando a desigualdade social no Canadá e piorando as condições de trabalho e pobreza no Brasil. Para a autora, existem desafios para os dois países. No Canadá, as formas de trabalho atípicas, porém regulamentadas, o desafio é o da criação de uma nova regulamentação do mercado de trabalho para assegurar e expandir seus direitos, dotando-o de capacidade organizativa e de representação sindical. No Brasil, o desafio está em regulamentar uma nova legislação sindical, fortalecendo o poder da representação dos trabalhadores, inclusive no mercado informal, garantindo o mínimo de direitos trabalhistas e seguridade social.

Cruz, Sarsur, e Amorim (2012) analisam do ponto de vista dos sindicatos, em que medida a utilização de gestão de competências tem sido objeto de ação sindical, sendo um tipo de gestão de pessoas considerada moderna. A pesquisa utilizou o método qualitativo, utilizando pesquisa documental e de campo. Os resultados demonstraram que a discussão de gestão de competências é um assunto ausente nas negociações coletivas e desconhecida pelos sindicatos. Observou-se também que o Estado não influencia na questão da gestão de competências empregada nas organizações, tornando estas uma ação imperativa sobre os trabalhadores. 


\subsection{Síntese conceitual}

Tabela 2 Síntese dos conceitos e discussões apresentados no refencial teórico.

\begin{tabular}{|c|c|c|}
\hline Conceito & Definição e discussões & Autores \\
\hline Gestão de pessoas & $\begin{array}{l}\text { - Gestão de pessoas caracteriza-se como } \\
\text { um conjunto de políticas e práticas que } \\
\text { permitem a conciliação de expectativas } \\
\text { entre a organização e as pessoas, para que } \\
\text { ambas possam realizá-las ao longo do } \\
\text { tempo; } \\
\text { - A mudança da utilização do termo } \\
\text { "recurso" para "pessoas" ocorreu porque } \\
\text { o papel do homem no trabalho vem se } \\
\text { transformando. }\end{array}$ & Fischer (2002) \\
\hline $\begin{array}{l}\text { Gestão estratégica de } \\
\text { RH }\end{array}$ & $\begin{array}{l}\text { - GERH tem como objetivo alinhar as } \\
\text { estratégias de recursos humanos com as } \\
\text { estratégias da organização, é o modelo de } \\
\text { implantações e atividades planejadas de } \\
\text { recursos humanos destinadas a permitir } \\
\text { que uma organização alcance suas metas; } \\
\text { - Relação entre sistemas de trabalho de } \\
\text { alto desempenho (high performance work } \\
\text { sistems - HPWS) e o desempenho da } \\
\text { empresa. } \\
\text { - A gestão estratégica de pessoas pode } \\
\text { apresentar-se de três formas: } \\
\text { universalista, contingencial } \\
\text { configuracional; } \\
\text { - Definição do construto da vantagem de } \\
\text { recursos humanos como consistindo em } \\
\text { dois componentes: vantagem de capital } \\
\text { humano e vantagem dos processos } \\
\text { organizacionais; } \\
\text { - A estratégia deve se encaixar em três } \\
\text { variáveis conceituais genéricas: práticas } \\
\text { de gestão de recursos humanos, } \\
\text { habilidades dos funcionários } \\
\text { comportamentos dos funcionários; }\end{array}$ & Wright e Snell (1998) \\
\hline
\end{tabular}




\begin{tabular}{|c|c|c|}
\hline & $\begin{array}{l}\text { - A GERH pode apresentar-se em duas } \\
\text { formas de abordagem "hard" e "soft". }\end{array}$ & Legge (2005) \\
\hline \multirow[t]{5}{*}{ Relações de trabalho } & $\begin{array}{l}\text { - As relações de trabalho consistem em } \\
\text { um complexo de relações entre a } \\
\text { administração de empresas, os } \\
\text { trabalhadores e as agências } \\
\text { governamentais; } \\
\text { - As empresas são capazes de } \\
\text { implementar a gestão de recursos } \\
\text { humanos e atingir as metas corporativas } \\
\text { na medida em que eles alistam a } \\
\text { cooperação de outras partes interessadas } \\
\text { que têm capacidade de ajudar ou impedir, } \\
\text { incluindo componentes internos, como } \\
\text { funcionários e componentes externos, } \\
\text { como comunidades, sindicatos e }\end{array}$ & Kaufman (2015) \\
\hline & $\begin{array}{l}\text { governos; } \\
\text { - A ideologia de um SRT significa um } \\
\text { conjunto de ideias compartilhado pelos } \\
\text { atores sobre o lugar e papel de si mesmos } \\
\text { e dos demais atores no processo de }\end{array}$ & Horn (2011) \\
\hline & $\begin{array}{l}\text { regulação; } \\
\text { - Os atores em relação compreendem os } \\
\text { trabalhadores, a gerência e o governo e }\end{array}$ & Nogueira (2008) \\
\hline & $\begin{array}{l}\text { suas escolhas estratégicas; } \\
\text { - O sistema de relações de trabalho } \\
\text { oferece elementos para análise do } \\
\text { contexto, dos seus atores, das instituições } \\
\text { e das suas regras de funcionamento e as } \\
\text { mudanças dessas regras também; }\end{array}$ & Amorim (2007) \\
\hline & $\begin{array}{l}\text { - Todo sistema de relações do trabalho } \\
\text { administra o conflito através de um } \\
\text { conjunto de procedimentos. Existem dois } \\
\text { tipos de sistemas: o estatutário e o } \\
\text { negocial. }\end{array}$ & Pastore e Zylberstajn (1988) \\
\hline
\end{tabular}

Fonte: Elaboração da autora.

A discussão dos conceitos gestão estratégica de recursos humanos e relações de trabalho apresentados neste referencial teórico demonstram a relevância destes temas para a área de gestão de pessoas. Para operacionalizar a pesquisa destes conceitos apresentados 
neste referencial teórico, visto que são temas que se apresentam como fenômenos sociais pouco explorados para o setor de refeições coletivas, optou-se por utilizar a metodologia de pesquisa qualitativa, descritiva e exploratória, que serão apresentadas adiante. 


\section{POSIÇÕES METODOLÓGICAS}

\subsection{Método de pesquisa}

Para identificar como a gestão estratégica de recursos humanos se apresenta nas empresas de restaurantes de refeições coletivas do estado de São Paulo, com foco nas relações de trabalho, propõe-se para esta pesquisa a abordagem qualitativa, exploratória e descritiva. A abordagem qualitativa justifica-se de acordo com Richardson (1999), por apresentar estratégias adequadas para se entender a natureza de um fenômeno social. Além disso, a abordagem qualitativa propicia "partilha densa com pessoas, fatos e locais que constituem objetos de pesquisa, para extrair desse convívio os significados visíveis e latentes que somente são perceptíveis a uma atenção sensível" (Chizzotti, 2006, p.28). Segundo Gil (1994), as pesquisas exploratórias têm como principal finalidade desenvolver, esclarecer e modificar conceitos e ideias, com vistas na formulação de problemas mais precisos ou hipóteses pesquisáveis para estudos posteriores. As pesquisas descritivas têm como objetivo primordial a descrição das características de determinada população, ou fenômeno, ou o estabelecimento de relação entre as variáveis.

A estratégia escolhida para esta pesquisa é a do estudo de casos múltiplos. Yin (2015) relata que os métodos de pesquisa dependem de três condições: o tipo de questão de pesquisa proposta, o controle que o pesquisador exerce sobre os eventos comportamentais reais e o enfoque sobre os fenômenos contemporâneos em oposição aos históricos. Em geral, os estudos de caso são o método preferido quando questões "como" ou "por que" são propostas, o investigador tem pouco controle sobre os eventos e o enfoque está sobre um fenômeno contemporâneo no contexto da vida real. Em um estudo de caso coletivo (ou estudo de caso múltiplo), o pesquisador pode selecionar várias unidades de pesquisa em vários locais ou várias unidades de pesquisa dentro de um único local físico. Muitas vezes, o investigador propositadamente seleciona vários casos para mostrar diferentes pontos de vista sobre a questão (Creswell, 2007).

Tanto o objetivo deste estudo como o objeto a ser investigado estão em conformidade com os pressupostos anteriores, recomendados pela literatura especializada. Esta pesquisa busca identificar e analisar a gestão estratégica de recursos humanos nas empresas de restaurantes de refeições coletivas no estado de São Paulo, tendo como foco as relações de trabalho, cujo setor possui pouca informação e conhecimento a respeito deste tema. 
Foram utilizadas técnicas de pesquisa de análise documental do documento da convenção coletiva de trabalho do setor de refeições coletivas 2018/2019 e conteúdo dos seus respectivos sites, entrevistas semiestruturadas com gestores de RH e sindicalistas e análise de dados de fontes secundárias. A triangulação de dados utiliza fontes diferentes para obtenção de evidências, tornando-se um ponto forte da coleta de dados (Yin, 2005). Segundo Cresswell (2007), um estudo qualitativo eficaz tem várias características, como a utilização de procedimentos rigorosos e múltiplos métodos de coleta de dados. O levantamento bibliográfico será a partir de material já publicado, constituído principalmente de livros, artigos de periódicos para descrição e abordagem geral do tema.

\subsection{Planejamento operacional}

\subsubsection{Procedimentos de revisão de bibliografia}

O levantamento bibliográfico sobre gestão estratégica de RH, relações de trabalho e empresas de refeições coletivas, bem como destes termos na língua inglesa, privilegiou pela busca de artigos publicados de 2000 a Junho de 2018 em revistas com fator de impacto igual ou superior a 1,4, identificados na plataforma de busca Web of Science e revistas com classificação A1, A2, B1 e B2 nas plataformas Spell e Periódicos Capes. A primeira seleção de artigos baseou-se na citação de três termos: "gestão estratégica de RH", "relações de trabalho" e "empresas de refeições coletivas" em seus títulos, entretanto, nenhum artigo foi encontrado. Ao pesquisar artigos com a citação de ao menos dois termos no título, o resultado foi semelhante, nenhum artigo foi encontrado. A busca foi então estendida por artigos que apresentassem a combinação dos três termos em seu resumo ou palavra-chave, nenhum artigo foi encontrado novamente.

Diante da escassez de artigos publicados com a citação dos três termos, ampliou-se a busca para os termos "gestão estratégica de pessoas" e "relações de trabalho" de forma mais ampla, combinadas entre si e isoladas, selecionando o critério de tópicos. Utilizaramse os seguintes termos em inglês para realização desta busca: "strategic human resource management", "employment relation (s)" e "employment relationship (s)". Priorizou-se a busca de artigos publicados de 2000 a 2018 em revistas de alto fator de impacto da área de recursos humanos, identificados na plataforma de busca Web of Science. Inicialmente encontrou-se 1800 artigos, após seleção das revistas de alto fator de impacto da área de recursos humanos, foram encontrados 354 artigos. Após a leitura dos resumos, selecionou- 
se nove artigos que abordavam as palavras-chaves com coerência ao objeto em estudo. Dos artigos selecionados, quatro tratam de gestão estratégica de $\mathrm{RH}$, um tratam de relações de trabalho e quatro tratam da combinação destes dois conceitos.

Tabela 2 Resultado da pesquisa bibliométrica em revistas internacionais.

\begin{tabular}{lcc}
\hline \multicolumn{1}{c}{ Journal } & Fator de Impacto & No de artigos \\
\hline Human Resource Management & 1,82 & 5 \\
International Journal of Human Resource Management & 1,65 & 1 \\
Personnel Review & 1,43 & 1 \\
Human Resource Management Review & 2,37 & 1 \\
Human Resource Management Journal & 2,15 & 1 \\
\hline
\end{tabular}

Fonte: Elaboração da autora.

A busca em periódicos nacionais ocorreu na plataforma Scielo, utilizando-se os termos "gestão estratégica de recursos humanos", "gestão estratégica de pessoas" e "relações de trabalho", combinados entre si e isolados, selecionando o critério de all indexes. Inicialmente foram encontrados 71 artigos, após seleção de revistas classificadas pela Qualis como A1, A2 e B1, resultaram em 27 artigos. Após a leitura dos resumos, foram selecionados 2 artigos que abordavam as palavras-chaves com coerência ao objeto de estudo.

Tabela 3 Resultados da pesquisa bibliométrica em revistas nacionais.

\begin{tabular}{lcc}
\hline \multicolumn{1}{c}{ Periódico } & Classificação & No de artigos \\
\hline Revista de Administração Contemporânea & A2 & 1 \\
Revista de Administração de Empresas & A2 & 1
\end{tabular}

Fonte: Elaboração da autora.

\subsubsection{Coleta de Dados}

\subsubsection{Análise documental}


A análise documental de dados das empresas estudadas foi realizada a partir dos materiais e conteúdo dos seus respectivos sites, observando o histórico das empresas, certificações, registros da missão, valores e condutas éticas, e descrições das atividades do negócio como número de funcionários, quantidade de clientes e volume de produção. Foi analisado também o documento dos acordos estabelecidos na Convenção Coletiva 2018/2019 do setor de refeições coletivas.

\subsubsection{Análise de dados de fontes secundárias}

A análise de dados secundários foi voltada para a formulação do contexto e mapeamento do campo de pesquisa. A base de dados utilizada foi a Relação Anual de Informações Sociais (RAIS). A RAIS é uma base dados de monitoramento do número de empregos e a movimentação da mão de obra empregada no Brasil, elaborada pelo ministério da economia.

Os parâmetros utilizados na base de dados foram RAIS vínculos, ano- corrente a 2002, geográfico- Região Administrativa de São Paulo², setorial- $\mathrm{CNAE}^{3} 2.0$ e subclassefornecimento de alimentos preparados preponderantemente para empresas. O ítem vínculos foi utilizado de forma isolada e combinada comforam as opções faixa de remuneração média e faixa tempo de emprego; e no ítem individual, escolaridade após 2005, faixa etária e sexo do trabalhador. Os dados extraídos da base de dados da RAIS foram agrupados e organizados em tabelas na plataforma Excel, utilizando as informações pertinentes aos objetivos desta pesquisa.

\subsubsection{Entrevistas semiestruturadas}

As entrevistas foram realizadas com diretores, gerentes e coordenadores das áreas de RH de cada empresa e sindicalistas representantes do setor de refeições coletivas. Foram escolhidas quatro grandes empresas do estado de São Paulo. O número de casos suficientes

\footnotetext{
${ }^{2}$ A Região Administrativa de SP inclui as cidades de São Paulo, Campinas, São José dos Campos, Sorocaba, Araçatuba, Barretos, Bauru, Campinas, Central, Franca, Marília, Presidente Prudente, Registro, Santos e São José do Rio Preto.

${ }^{3}$ CNAE: Classificação nacional de atividades econômicas.
} 
para estudo de casos múltiplos é uma questão bastante discutida, sobre a qual poucos pesquisadores se posicionam claramente. Embora não exista um número ideal de casos, Eisenhardt (1989) considerava que para a geração de teoria por meio dos casos, um número entre quatro e dez casos produz bons resultados. Com menos de quatro casos, muitas vezes é difícil gerar teoria com complexidade. As entrevistas serão efetuadas presencialmente, gravadas e transcritas em sua totalidade.

O questionário foi baseado nas assertivas da pesquisa Cranet, apresentadas na tabela 6 e 7. A pesquisa Cranet foi desenvolvida em uma rede internacional de escolas de negócios ao redor do mundo. Esta pesquisa surgiu na Universidade de Cranfield, Inglaterra, no final dos anos 1980 (Amorim, 2017). O principal objetivo da pesquisa é "investigar as políticas e práticas de gestão de pessoas adotadas nas organizações por meio de um instrumento de pesquisa único" (CRANET, 2015). O foco de toda a organização da Cranet, juntamente com o status sênior do respondentes, torna a pesquisa mais apropriada para a análise da integração estratégica (Vernon \& Brewster, 2013).

As definições operacionais e variáveis de controle serão apresentadas nas tabelas 6 e 7, assim como as questões utilizadas na pesquisa Cranet relacionadas a cada definição operacional e a cada variável. 
Tabela 4 Definições conceituais, operacionais e questões para as entrevistas.

\begin{tabular}{|c|c|c|c|c|}
\hline Conceito & Definição Conceitual & $\begin{array}{c}\text { Definições } \\
\text { Operacionais }\end{array}$ & Questões & Autores \\
\hline $\begin{array}{l}\text { Gestão } \\
\text { estratégica } \\
\text { de } \\
\text { recursos } \\
\text { humanos }\end{array}$ & $\begin{array}{l}\text { A GERH tem como } \\
\text { objetivo alinhar as } \\
\text { estratégias de recursos } \\
\text { humanos com as } \\
\text { estratégias da } \\
\text { organização, é o modelo } \\
\text { de implantações e } \\
\text { atividades planejadas de } \\
\text { recursos humanos } \\
\text { destinadas a permitir que } \\
\text { uma organização alcance } \\
\text { suas metas (Wright \& } \\
\text { McMahan, 1992). }\end{array}$ & $\begin{array}{l}\text { - Presença do } \\
\text { gestor de RH no } \\
\text { conselho; } \\
\text { - Envolvimento do } \\
\text { executivo de RH } \\
\text { nas decisões } \\
\text { estratégicas; } \\
\text { - Existência de } \\
\text { registro } \\
\text { documental das } \\
\text { estratégias de RH }\end{array}$ & $\begin{array}{l}\text { - A pessoa responsável } \\
\text { pelo RH tem lugar no } \\
\text { comitê executivo? } \\
\text { - Em que fase do } \\
\text { desenvolvimento da } \\
\text { estratégia de negócio o } \\
\text { responsável de RH é } \\
\text { envolvido? } \\
\text { - Sua organização tem } \\
\text { registrada por escrito a } \\
\text { missão, estratégia do } \\
\text { negócio e estratégia de } \\
\text { RH? }\end{array}$ & $\begin{array}{l}\text { (Purcell, 1995; } \\
\text { Brewster et al, 1997) } \\
\text { (Sheehan, 2005) } \\
\text { (Hope- Hailey et al, } \\
\text { 1997) }\end{array}$ \\
\hline $\begin{array}{l}\text { Relações } \\
\text { de } \\
\text { trabalho }\end{array}$ & $\begin{array}{l}\text { As relações de trabalho } \\
\text { consistem em um } \\
\text { complexo de relações } \\
\text { entre a administração de } \\
\text { empresas, os } \\
\text { trabalhadores e as } \\
\text { agências governamentais } \\
\text { (Dunlop, 1993). }\end{array}$ & $\begin{array}{l}\text { - Taxa de adesão à } \\
\text { sindicalização } \\
\text { - Atuação dos } \\
\text { sindicatos }\end{array}$ & $\begin{array}{l}\text { - Qual a proporção do } \\
\text { número total } \\
\text { empregados em sua } \\
\text { organização que são } \\
\text { sindicalizados? } \\
\text { - Em que extensão os } \\
\text { sindicatos influenciam a } \\
\text { organização? } \\
\text { - A organização reconhece } \\
\text { o sindicato para o } \\
\text { propósito da negociação } \\
\text { coletiva? } \\
\text { - A organização tem um } \\
\text { comitê consultivo ou } \\
\text { comissão } \\
\text { trabalhadores? }\end{array}$ & $\begin{array}{l}\text { (Crouch, 1993) } \\
\text { (Sisson, 1993) }\end{array}$ \\
\hline
\end{tabular}

Fonte: Adaptado de Vernon e Brewster (2013).

Tabela 5 Variáveis independentes e questões da pesquisa.

\begin{tabular}{clcc}
\hline $\begin{array}{c}\text { Variáveis } \\
\text { Independentes }\end{array}$ & \multicolumn{1}{c}{ Questões } & Autores \\
\hline $\begin{array}{c}\text { Tamanho da } \\
\text { organização }\end{array}$ & - Quantas pessoas são empregadas pela organização? & (Brewster et al, 2006) \\
& - Quantas pessoas estão empregadas no departamento de RH? & & \\
\hline $\begin{array}{c}\text { Características } \\
\text { da força de } \\
\text { trabalho }\end{array}$ & - Qual é a proporção de empregados: gerentes, especialistas e & (Vernon & \& Brewster, \\
& administrativos operacionais? & 2013) & \\
\hline
\end{tabular}

Fonte: Adaptado de Vernon e Brewster (2013) 
3.3 Interpretação e análise

As entrevistas foram gravadas em áudio e depois transcritas, procedeu-se então a análise de seu conteúdo. A análise de conteúdo considera as significações (conteúdo), sua forma e a distribuição desses conteúdos e formas e tem como objetivo principal sua manipulação (conteúdo e expressão). (Lakatos \& Marconi, 2001).

A análise de dados se baseou nas orientações de Miles, Huberman, \& Saldaña (2014), que justifica sua utilização quando o posicionamento teórico é o ponto de partida para a pesquisa. O modelo conceitual descreve, de forma narrativa ou gráfica, os fatores, variáveis ou conceitos mais importantes a serem investigados e as supostas relações entre eles. Uma lente teórica oferece um conjunto de conceitos e premissas que orientarão sua reflexão.

Miles et al. (2014) veem a análise de dados como três fluxos simultâneos de atividade: a condensação dos dados; a visualização dos dados; e a elaboração e verificação de conclusões. Os autores explicam que a condensação dos dados refere-se ao processo de selecionar, focando, simplificando, abstraindo e transformando os dados de anotações da pesquisa de campo ou transcrições das entrevistas. A visualização dos dados é a organização, a redução das informações, que permite conclusões e ações. Esta visualização pode ser feita através de matrizes, gráficos ou redes. A verificação e conclusão ocorrem desde o início da coleta de dados, quando o pesquisador procede as decisões do significado de cada achado. Esse processo é contínuo e iterativo, ou seja, é possível que ao exibir dados, volte-se à condensação para aperfeiçoamento ou que durante o processo de condensação alguns resultados já comecem a aparecer (Miles et al. , 2014). Este trabalho utilizou-se da condensação dos dados a partir das transcrições das entrevistas e a visualização dos dados através de matrizes, utilizando-se a plataforma Excel. A verificação e conclusão foram realizadas conforme as orientações de Miles et al. (2014), representados na figura 7. 
Figura 7 Componentes da análise de dados: modelo interativo.

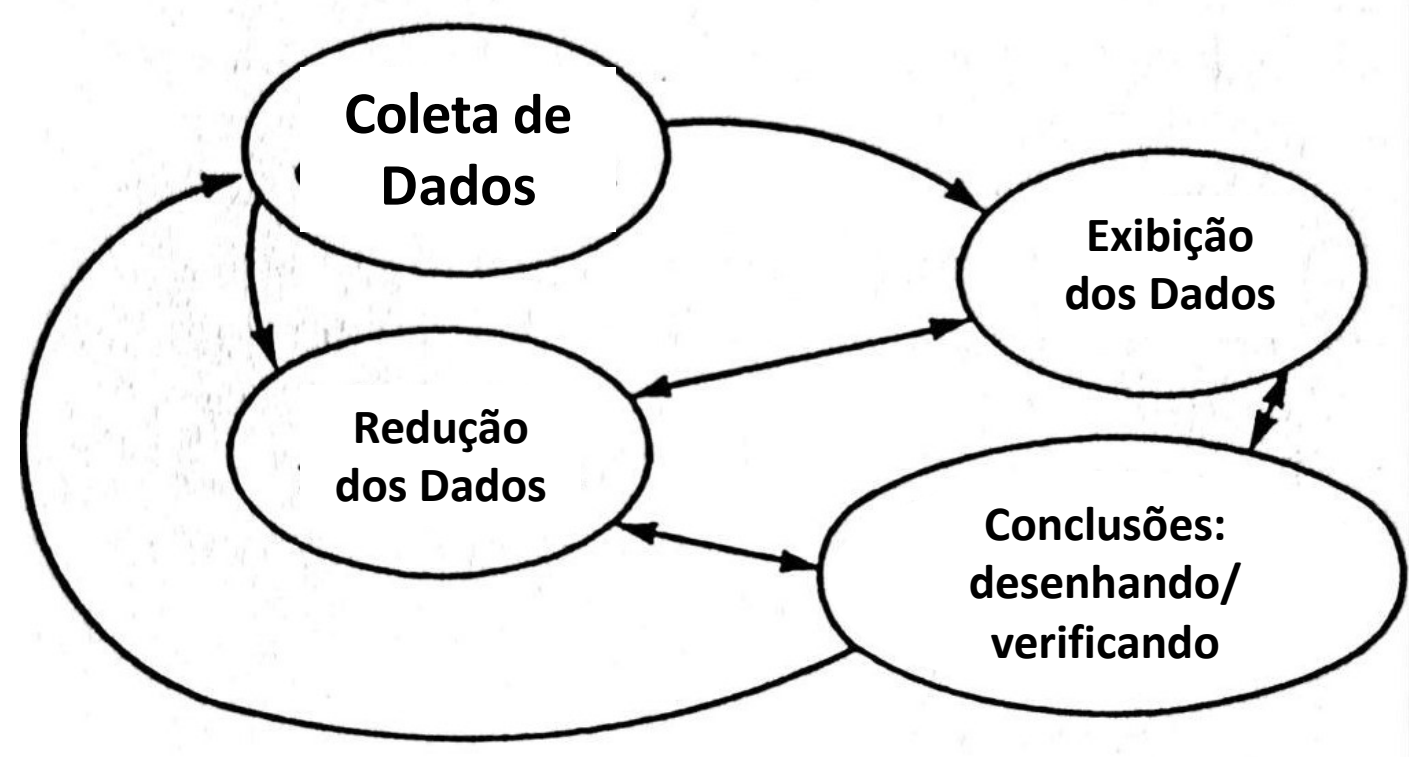

Fonte: Adaptado de Miles, Huberman, e Saldaña (2014).

\subsection{Procedimentos operacionais das entrevistas}

Para ajustes e correções do instrumento de pesquisa foram realizados dois pré-testes. O primeiro teste foi aplicado a uma ex-gerente de $\mathrm{RH}$, atuando em seu último trabalho há três anos, e atual consultora em RH. O segundo teste foi realizado com uma gerente de RH que atua há um ano e quatro meses em uma instituição de educação. Após os testes houve reordenamento das questões para melhor organização das respostas e informações e eliminação de uma pergunta que resultou em conteúdo semelhante à outra questão.

Quatro entrevistas com gestores de RH de grandes empresas do setor de refeições coletivas foram realizadas. Denominou-se as empresas de Alpha, Beta, Gamma e Delta. As entrevistas das empresas Alpha, Beta e Gamma ocorreram na sede do sindicato patronal das empresas de refeições coletivas e a entrevista da Empresa Delta ocorreu na sede da própria organização. Três presidentes de sindicatos das principais regiões do estado de São Paulo também foram entrevistados. Duas entrevistas ocorreram na sede de um dos sindicatos e a terceira na própria sede do sindicato em que o entrevistado presidia.

O entrevistado da Empresa Alpha, denominado com o código Ent.Alpha, é do sexo masculino e com idade de 54 anos. Trabalha nesta organização há 31 anos. Seu cargo atual é de diretor de relações de trabalho. Graduou-se em administração de empresas e direito, 
depois se especializou em direito trabalhista e cursou um MBA em gestão de negócios. Iniciou sua carreira na área de departamento pessoal no setor de folha de pagamento em uma pequena empresa, após isso, realizou o mesmo trabalho já na Empresa Alpha. Neste período começou a ter contato com relações sindicais, pois não havia uma área na empresa específica para estas questões. Durante esta fase a Empresa Alpha possuía mil e duzentos empregados e começou a crescer, adquirindo outras empresas, e sua carreira ascendeu dentro da organização, passando a ser encarregado de departamento pessoal e folha, depois chefe de departamento, coordenador de relações sindicais, gerente de relações de trabalho e diretor de relações de trabalho. Atualmente exerce também a função de presidente do sindicato patronal do setor de refeições coletivas. A entrevista realizada na Empresa Alpha ocorreu na sede do Sindicato patronal de refeições coletivas.

O entrevistado da Empresa Beta, denominado pelo código Ent.Beta, é do sexo feminino e possui 32 anos. Atuou a partir de 2005 na área jurídica de diversas empresas, incluindo relações trabalhistas e sindicais. Trabalha nesta empresa há dois anos e três meses. Seu cargo atual é coordenadora de relações do trabalho e sua formação educacional é graduação em direito.

O entrevistado da Empresa Gamma, denominado Ent.Gamma, é do sexo masculino e possui 64 anos. Sua formação acadêmica é de nível superior completo em administração de empresas. Trabalha nesta empresa há 15 anos e seu cargo atual é consultor de relações sindicais. Sua formação é de nível superior. Sua trajetória profissional contempla 15 anos em outra empresa de refeições coletivas, inicialmente como analista de RH e evoluindo para gerente de RH, sua última posição nesta empresa. Iniciou sua carreira na Empresa Gamma como coordenador de RH e então se tornou gerente de RH. Em 2011 se aposentou e seu vínculo com a organização atualmente é como consultor.

O entrevistado da Empresa Delta, Ent.Delta, é do sexo masculino e possui 53 anos de idade. Trabalha na organização há 20 anos e seu cargo atual é gerente de RH. Sua formação educacional é graduação em administração de empresas com especialização em RH. A carreira do entrevistado iniciou-se com a idade de 20 anos no departamento pessoal, assim chamado na época, em um grupo de cerâmica localizado em Santa Catarina, atuando em diversos setores como folha de pagamento, demissão e etc. Após a compra de uma empresa em São Paulo, mudou-se para esta cidade como encarregado de RH. Trabalhou em outras duas ou três empresas até iniciar na Empresa Delta.

O entrevistado sindicalista 1, Sind.01, é do sexo masculino e possui 43 anos. Está atuando no sindicato há vinte e cinco anos e seu cargo atual é de presidente. Sua formação 
educacional é o ensino médio completo. Sua carreira no sindicato iniciou-se após um convite do presidente na época e, assim, tornou-se suplente no primeiro mandato. Em seu segundo mandato, assumiu o cargo de secretário geral e no meio do terceiro mandato tornou-se presidente. Profissionalmente é licenciado de uma empresa de refeições coletivas.

O entrevistado sindicalista 2, Sind.02, é do sexo masculino e possui 70 anos. Trabalha no sindicato há trinta anos e seu cargo atual é presidente. Sua formação educacional é ensino superior em direito. Sua carreira iniciou-se aos quinze anos de idade como office boy. Trabalhou em uma empresa de refeições coletivas por mais ou menos vinte anos, de auxiliar de escritório à chefia de $\mathrm{RH}$. A própria empresa sugeriu que o sindicalista 2 participasse da fundação de uma entidade profissional e assim iniciou sua carreira sindical.

O entrevistado sindicalista 3, Sind.03, é do sexo masculino e tem 47 anos. Trabalha no sindicato há vinte e três anos e seu cargo atual é presidente do sindicato. Sua formação é de ensino médio técnico completo em nutrição. Sua carreira profissional iniciou-se há onze anos no setor de alimentação, no terceiro do curso técnico iniciou seu trabalho em uma unidade de alimentação e nutrição (UAN) localizada em uma fábrica de biscoitos. Nesta empresa trabalhava um diretor de sindicato que o convidou para fazer parte das reuniões do sindicato. Após um período convidou-o para fazer parte da diretoria de um sindicato que estava se desmembrando de outro. Entrou no conselho fiscal do sindicato e em 2008 iniciou sua atividade exclusivamente no sindicato como diretor. Em 2012 tornou-se então presidente.

Tabela 6 Dados dos entrevistados.

\begin{tabular}{|c|c|c|c|c|}
\hline Entrevistado - Código & Cargo & Gênero & Idade & Escolaridade \\
\hline Entrevistado Alpha - Ent.Alpha & $\begin{array}{l}\text { Diretor de relações de } \\
\text { trabalho } \\
\text { Coordenadora }\end{array}$ & Masculino & 54 anos & Pós Graduação \\
\hline Entrevistado Beta- Ent.Beta & $\begin{array}{l}\text { relações de trabalho } \\
\text { Consultor de relacões }\end{array}$ & Feminino & 32 anos & Graduação \\
\hline Entrevistado Gamma - Ent.Gamma & sindicais & Masculino & 64 anos & Graduação \\
\hline Entrevistado Delta - Ent.Delta & Gerente de RH & Masculino & 53 anos & Pós Graduação \\
\hline Sindicalista 1 - Sind.01 & $\begin{array}{l}\text { Presidente do } \\
\text { sindicato }\end{array}$ & Masculino & 43 anos & Ensino médio \\
\hline Sindicalista 2 - Sind. 02 & $\begin{array}{l}\text { Presidente do } \\
\text { sindicato }\end{array}$ & Masculino & 70 anos & Graduação \\
\hline Sindicalista 3 - Sind.03 & $\begin{array}{l}\text { Presidente do } \\
\text { sindicato }\end{array}$ & Masculino & 47 anos & Ensino médio \\
\hline
\end{tabular}

Fonte: Elaboração da autora. 
Tabela 7 Dados das entrevistas.

\begin{tabular}{llcc}
\hline Entrevistado & Data & Duração & Meio \\
\hline Ent.Alpha & $11 / 12 / 2018$ & $34 \mathrm{~min}$. & Presencial \\
Ent.Beta & $07 / 02 / 2019$ & $35 \mathrm{~min}$. & Presencial \\
Ent.Gamma & $07 / 02 / 2019$ & $35 \mathrm{~min}$. & Presencial \\
Ent.Delta & $23 / 01 / 2019$ & $44 \mathrm{~min}$. & Presencial \\
Sind.01 & $30 / 01 / 2019$ & $48 \mathrm{~min}$. & Presencial \\
Sind.02 & $21 / 02 / 2019$ & $25 \mathrm{~min}$. & Presencial \\
Sind.03 & $28 / 02 / 2019$ & $23 \mathrm{~min}$. & Presencial \\
\hline \multicolumn{1}{c}{ Total } & & $\mathbf{2 4 5}$ min. &
\end{tabular}

Fonte: Elaboração da autora. 


\section{RESULTADOS E ANÁLISE DOS DADOS}

4.1 O setor de refeições coletivas no Brasil

Neste subcapítulo serão apresentados o histórico da alimentação, relacionando-o às empresas de refeições coletivas e seus objetivos, e a descrição do setor estudado. Após esta definição do contexto do objeto de pesquisa, apresenta-se quais são os sindicatos mais representativos do setor de refeições coletivas e as características das suas negociações coletivas.

\subsubsection{A alimentação}

No passado, a alimentação era demarcada geográfica e temporalmente (Pereira, 2014). Geográfica porque o alimento era pertinente à determinada região ou nação, e temporal devido à divisão do tempo por meio da colheita e plantação. $\mathrm{O}$ alimento estava presente nas festas religiosas, nas colheitas, no casamento e em outras comemorações sempre como elemento principal do evento. No comportamento humano alimentar de um indivíduo, não existe apenas a busca pela satisfação fisiológica, pois também engloba aspectos cognitivos e afetivos. A refeição era cercada de cerimonial, de expressão de sociabilidade, de ritual político, um verdadeiro rito de iniciação para a convivência (Pereira, 2014).

Com a urbanização, a entrada da mulher no mercado de trabalho e a crescente industrialização dos alimentos, valorizou-se cada vez mais a praticidade e a redução do tempo do preparo e consumo de alimentos. As últimas décadas do século $\mathrm{XX}$ foram marcadas por uma revolução sociocultural, por um mundo mais integrado e globalizado, que impactou as culturas de diferentes sociedades (Hall, 1997). Diante de tais mudanças, o tempo e o espaço das refeições também mudaram, e a sociedade urbana industrial passou a realizar as refeições de forma rápida, sendo elas feitas fora do ambiente doméstico (Pereira, 2014). Em meados do século XX, com o desenvolvimento da ciência da nutrição é que se identificou que uma alimentação equilibrada era um recurso importante e muitas vezes vital (Mesomo, 1994). Constatou-se também que uma boa alimentação era indispensável para manter uma produção adequada e obter eficiência no trabalho (Pereira, 2014). 
A qualidade de vida do trabalhador é um fator importante a ser considerado durante o desenvolvimento das atividades de uma organização. Para um bom desenvolvimento da qualidade de vida, deve-se considerar o bem-estar alimentar do indivíduo. Conforme Pereira (2014) afirma, observou-se a crescente preocupação das empresas com a saúde dos seus funcionários, pois problemas nutricionais estão diretamente ligados aos problemas de saúde da atualidade, como obesidade, dislipidemias, problemas cardiovasculares etc. O rendimento do trabalhador apresenta relação direta com seu estado nutricional, auxiliando no aumento da produtividade (Pereira, 2014). Diante deste cenário surgiram na década de 20, no Brasil, as Unidades de Alimentação e Nutrição (UANs) com o objetivo de fornecer refeições equilibradas nutricionalmente visando a promoção da saúde dos funcionários.

\subsubsection{Descrição do setor de refeições coletivas no Brasil}

A dimensão e a importância do setor de refeições coletivas na economia nacional podem ser medidas a partir dos números gerados pelo segmento no ano 2017. Esse mercado como um todo forneceu 12 milhões de refeições/dia, movimentou R 18 bilhões por ano em valor corrente, ofereceu 210 mil empregos diretos, consumiu diariamente um volume de 7 mil toneladas de alimentos e representou para os governos uma receita de $\mathrm{R} \$ 2,5$ bilhões anuais entre impostos e contribuições, segundo ABERC (2018), Associação Brasileira de Empresas de Refeições Coletivas, e existem 40 empresas de refeições coletivas associadas à esta instituição no estado de São Paulo.

Observa-se nas tabelas a seguir que o setor de refeições coletivas esteve em constante crescimento, tendo seu faturamento em 2010 de R $\$ 10,8$ bilhões em valores reais e em 2017 de R \$ 18,2 bilhões, um aumento equivalente a 68\%. No entanto, o sistema de autogestão quando as refeições são produzidas pela própria empresa e não por uma Empresa de refeições coletivas - teve uma queda de $\mathrm{R} \$ 600$ milhões para $\mathrm{R} \$ 420$ milhões, próximo a 30\%.

Tabela 8 Faturamento em bilhões de reais do setor de alimentação coletiva no Brasil de 2010 até 2017.

\begin{tabular}{ccccccccc}
\hline Subsetor & $\mathbf{2 0 1 0}$ & $\mathbf{2 0 1 1}$ & $\mathbf{2 0 1 2}$ & $\mathbf{2 0 1 3}$ & $\mathbf{2 0 1 4}$ & $\mathbf{2 0 1 5}$ & $\mathbf{2 0 1 6}$ & $\mathbf{2 0 1 7}$ \\
\hline $\begin{array}{l}\text { Refeições } \\
\text { Coletivas }\end{array}$ & 10,8 & 13,4 & 14,7 & 16,6 & 18,3 & 17,8 & 16,9 & 18,2 \\
Autogestão & 0,6 & 0,7 & 0,6 & 0,6 & 0,5 & 0,48 & 0,44 & 0,42 \\
\hline
\end{tabular}

Fonte: Adaptado ABERC (2018). 
$\mathrm{Na}$ tabela 8, percebe-se que em todos os anos apresentados, a quase totalidade das refeições produzidas pelo setor são das empresas de refeições coletivas.

Tabela 9 Distribuição por subsetor da quantidade de refeições em milhões/dia no Brasil de 2010 até 2017.

\begin{tabular}{ccccccccc}
\hline Subsetor & $\mathbf{2 0 1 0}$ & $\mathbf{2 0 1 1}$ & $\mathbf{2 0 1 2}$ & $\mathbf{2 0 1 3}$ & $\mathbf{2 0 1 4}$ & $\mathbf{2 0 1 5}$ & $\mathbf{2 0 1 6}$ & $\mathbf{2 0 1 7}$ \\
\hline $\begin{array}{l}\text { Refeições } \\
\text { Coletivas }\end{array}$ & 9,4 & 10,5 & 10,9 & 11,7 & 12,2 & 11,7 & 11,0 & 12,0 \\
Autogestão & 0,19 & 0,15 & 0,11 & 0,10 & 0,08 & 0,07 & 0,06 & 0,05 \\
\hline
\end{tabular}

Fonte: Adaptado ABERC (2018)

A seguir apresentam-se os dados a respeito dos vínculos do setor de refeições coletivas para os anos de 2015 a 2017 , tomando por base a RAIS ${ }^{4}$.

Tabela 10 Número de trabalhadores do setor de refeições coletivas no Brasil de 2015 a 2017.

\begin{tabular}{lcccccc}
\hline Região do Brasil & $\mathbf{2 0 1 5}$ & $\mathbf{\%}$ & $\mathbf{2 0 1 6}$ & $\mathbf{\%}$ & $\mathbf{2 0 1 7}$ & $\mathbf{\%}$ \\
\hline Norte & 9.808 & 4,7 & 9.832 & 4,9 & 8.436 & 4,4 \\
Nordeste & 25.703 & 12,4 & 25.791 & 12,9 & 24.764 & 12,8 \\
Sudeste & 129.215 & 62,2 & 123.689 & 61,6 & 120.238 & 62,2 \\
Sul & 32.059 & 15,4 & 30.546 & 15,2 & 29.003 & 15,0 \\
Centro-Oeste & 10.881 & 5,2 & 10.782 & 5,4 & 10.722 & 5,6 \\
\hline Total & 207.666 & 100 & 200.640 & 100 & 193.163 & 100 \\
\hline
\end{tabular}

Fonte: Elaborado pela autora a partir de RAIS (2018).

No que se refere à distribuição dos vínculos de contratação do setor de refeições coletivas no Brasil, nota-se que houve um decréscimo no número de trabalhadores entre 2015 e 2017, sendo que neste ano existiam 193.163 de vínculos. Entre as regiões do País, a maior parcela de vínculos encontra-se no Sudeste, com aproximadamente $62 \%$ do total em todos os anos observados.

\footnotetext{
${ }^{4}$ RAIS: Relação Anual de Informações Sociais, banco de dados do mercado de trabalho brasileiro, elaborada pelo ministério da economia do Brasil.
} 
Tabela 11 Número de trabalhadores do setor de refeições coletivas no estado de São Paulo de 2015 a 2017.

\begin{tabular}{lcccccc}
\hline \multicolumn{1}{c}{ Região Adm SP } & $\mathbf{2 0 1 5}$ & $\mathbf{\%}$ & $\mathbf{2 0 1 6}$ & $\mathbf{\%}$ & $\mathbf{2 0 1 7}$ & $\mathbf{\%}$ \\
\hline São Paulo & 37.624 & 54,3 & 37.690 & 54,3 & 38.758 & 55,7 \\
Campinas & 17.842 & 25,8 & 17.718 & 25,5 & 18.211 & 26,2 \\
S. J. Campos & 4.375 & 6,3 & 4.855 & 7,0 & 4.804 & 6,9 \\
Sorocaba & 4.973 & 7,2 & 4.533 & 6,5 & 3.676 & 5,3 \\
Outras & 4.474 & 6,5 & 4.674 & 6,7 & 4.176 & 6,0 \\
\hline Total & 69.288 & 100 & 69.470 & 100 & 69.625 & 100 \\
\hline
\end{tabular}

Fonte: Elaborado pela autora a partir de RAIS (2018).

Com o foco no estado de São Paulo, constata-se que o número de vínculos do mercado de refeições coletivas no estado de São Paulo aumentou em $0,5 \%$ no período entre 2015 e 2017. A maior concentração de trabalhadores do setor está na região de São Paulo com $55,7 \%$ do total de trabalhadores e crescimento de 1,4\% entre 2015 e 2017 . Entre as demais regiões está Campinas, Sorocaba e São José dos Campos com participação de 26,2\%, 6,9\% e 5,3\%. No período de 2015 a 2017, as regiões de Campinas e São José dos Campos cresceram $0,4 \%$ e $0,6 \%$ respectivamente. Porém, em Sorocaba e outras cidades diminuiu o número de vínculos em $1,9 \%$ e $0,5 \%$ respectivamente.

Tabela 11 Número de trabalhadores do setor de refeições coletivas segundo o sexo no estado de São Paulo em 2017.

\begin{tabular}{lcccccc}
\hline Região Adm SP & Masculino & $\mathbf{\%}$ & Feminino & $\mathbf{\%}$ & Total & $\mathbf{\%}$ \\
\hline São Paulo & 10.110 & 26,1 & 28.648 & 73,9 & 38.758 & 100 \\
Campinas & 3.474 & 19,1 & 14.737 & 80,9 & 18.211 & 100 \\
S. J. Campos & 838 & 17,4 & 3.966 & 82,6 & 4.804 & 100 \\
Sorocaba & 614 & 16,7 & 3.062 & 83,3 & 3.676 & 100 \\
Outros & 864 & 20,7 & 3.312 & 79,3 & 4.176 & 100 \\
\hline Total & 15.900 & 22,8 & 53.725 & 77,2 & 69.625 & 100 \\
\hline
\end{tabular}

Fonte: Elaborado pela autora a partir de RAIS (2018).

O setor apresenta-se no estado de São Paulo com uma mão de obra de maioria feminina, sendo $77 \%$ trabalhadores do sexo feminino e $23 \%$ do sexo masculino. Estes valores são semelhantes para todo estado de São Paulo. 
Tabela 12 Faixa etária (anos) dos trabalhadores do setor de refeições coletivas no estado de São Paulo em 2017.

\begin{tabular}{lcccccccccc}
\hline Região Adm SP & $\mathbf{1 5}$ a 24 & $\mathbf{\%}$ & $\mathbf{2 5}$ a 39 & $\mathbf{\%}$ & $\mathbf{4 0}$ a 49 & $\mathbf{\%}$ & $\mathbf{5 0}$ ou mais & $\mathbf{\%}$ & Total & \% \\
\hline São Paulo & 3.976 & 10,3 & 16.727 & 43,2 & 10.998 & 28,4 & 7.057 & 18,2 & 38.758 & 100 \\
Campinas & 1.497 & 8,2 & 7.408 & 40,7 & 5.457 & 30,0 & 3.849 & 21,1 & 18.211 & 100 \\
S. J. Campos & 282 & 5,9 & 1.998 & 41,6 & 1.530 & 31,8 & 994 & 20,7 & 4.804 & 100 \\
Sorocaba & 290 & 7,9 & 1.588 & 43,2 & 1.013 & 27,6 & 785 & 21,4 & 3.676 & 100 \\
Outros & 365 & 8,7 & 1.841 & 44,1 & 1.212 & 29,0 & 758 & 18,2 & 4.176 & 100 \\
\hline Total & 6.410 & 9,2 & 29.562 & 42,5 & 20.210 & 29,0 & 13.443 & 19,3 & 69.625 & 100 \\
\hline
\end{tabular}

Fonte: Elaborado pela autora a partir de RAIS (2018).

A faixa etária de maior grupo dos trabalhadores do setor está entre 25 a 39 anos, $42,5 \%$. Somando-se ao grupo de faixa etária 40 a 49 anos, obtemos $71 \%$ de trabalhadores, o que demonstra ser um grupo predominantemente em idade adulta e meia-idade. $\mathrm{O}$ segundo grupo em participação é de empregados com 50 anos ou mais. Para todas as cidades o percentual de distribuição da faixa etária é semelhante.

Tabela 13 Escolaridade dos trabalhadores do setor de refeições coletivas segundo escolaridade no estado de São Paulo em 2017.

\begin{tabular}{|c|c|c|c|c|c|c|c|c|c|c|}
\hline Região Adm SP & \multicolumn{2}{|c|}{$\begin{array}{c}\text { Até } \\
\text { Fundamental }\end{array}$} & \multicolumn{2}{|c|}{ Ensino Médio } & \multicolumn{2}{|c|}{ Superior } & \multicolumn{2}{|c|}{ Pós graduação } & \multicolumn{2}{|c|}{ Total } \\
\hline São Paulo & 11.125 & 28,7 & 21.994 & 56,7 & 4.710 & 12,2 & 48 & 0,1 & 38.758 & 100 \\
\hline Campinas & 6.656 & 36,5 & 9.231 & 50,7 & 1.953 & 10,7 & 12 & 0,1 & 18.211 & 100 \\
\hline S. J. Campos & 1.945 & 40,5 & 2.483 & 51,7 & 287 & 6,0 & 2 & 0,0 & 4.804 & 100 \\
\hline Sorocaba & 1.493 & 40,6 & 1.705 & 46,4 & 403 & 11,0 & 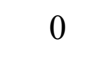 & 0,0 & 3.676 & 100 \\
\hline Outros & 1.091 & 26,1 & 2.427 & 58,1 & 588 & 14,1 & 0 & 0,1 & 4.176 & 100 \\
\hline Total & 22.310 & 32,0 & 37.840 & 54,3 & 7.941 & 11,4 & 68 & 0,1 & 69.625 & 100 \\
\hline
\end{tabular}

Fonte: Elaboração da autora a partir de RAIS (2018).

A escolaridade dos trabalhadores do setor de refeições coletivas tem como maior grupo os empregados com nível médio, 54,3\%. O segundo maior grupo é de trabalhadores com escolaridades até fundamental completo, $32,0 \%$ do total. Portanto, o perfil identificado é de empregados com escolaridade de média para baixa. As cidades de São José dos Campos e Sorocaba apresentam maior porcentagem de trabalhadores com escolaridade de até o ensino fundamental, 40,5\% e 40,6\% respectivamente, comparado às demais cidades. São José dos Campos também apresenta a menor porcentagem para o ensino superior, $6 \%$, 
aproximadamente a metade da média das outras cidades, 11,4\%. Observa-se então que essa cidade possui um grupo de trabalhadores com escolaridade mais baixa.

Tabela 14 Distribuição do número de trabalhadores segundo a remuneração mensal média (R\$) no estado de São Paulo em 2017.

\begin{tabular}{lcccccccccc}
\hline $\begin{array}{l}\text { Região Adm } \\
\text { SP }\end{array}$ & $\begin{array}{c}\text { Até } \\
\mathbf{1 5 0 0}\end{array}$ & $\mathbf{\%}$ & $\begin{array}{c}\mathbf{1 5 0 1} \mathbf{2 0 0} \\
\mathbf{2 0 0}\end{array}$ & $\mathbf{\%}$ & $\begin{array}{c}\mathbf{2 0 0 1} \mathbf{3 0 0} \\
\mathbf{3 0 0}\end{array}$ & $\mathbf{\%}$ & $\begin{array}{c}\text { Acima de } \\
\mathbf{3 0 0 0}\end{array}$ & $\mathbf{\%}$ & Total & \% \\
\hline São Paulo & 19.368 & 51,9 & 9.185 & 24,6 & 4.596 & 12,3 & 4.194 & 11,2 & 37.343 & 100 \\
Campinas & 8.416 & 48,7 & 4.923 & 28,5 & 2.215 & 12,8 & 1.741 & 10,1 & 17.295 & 100 \\
S. J. Campos & 3.485 & 74,1 & 628 & 13,3 & 362 & 7,7 & 230 & 4,9 & 4.705 & 100 \\
Sorocaba & 1.977 & 59,6 & 796 & 24,0 & 290 & 8,7 & 256 & 7,7 & 3.319 & 100 \\
Outros & 2.129 & 52,8 & 11.09 & 27,5 & 441 & 10,9 & 351 & 8,7 & 4.030 & 100 \\
\hline Total & 35.375 & 53,0 & 16.641 & 25,0 & 7.904 & 11,9 & 6.772 & 10,2 & 66.692 & 100 \\
\hline
\end{tabular}

Fonte: Elaboração da autora a partir de RAIS (2018).

A faixa de remuneração mais frequente é aquela com valores de até $\mathrm{R} \$ 1.500,00$, $53 \%$ do total de empregados do setor. Em São José dos Campos, esta porcentagem é ainda maior, 74,1\%, enquanto as demais cidades apresentam porcentagens semelhantes. Para os valores de remuneração de $\mathrm{R} \$ 1.501$ a $\mathrm{R}$ \$2.000, a cidade de São José dos Campos apresenta aproximadamente a metade da média do estado de São Paulo, 13,3\% e 25\% respectivamente. Quando analisamos a coluna de R 2.001 a R\$ 3.000 a cidade de Sorocaba aproxima-se de São José dos Campos em menores porcentagens do estado de São Paulo. Para os valores acima de R \$3.000, São José dos Campos apresenta novamente a menor porcentagem, sendo a metade da média do estado de São Paulo, 4,9\% e 10,2\% respectivamente. Observa-se então que tanto a menor escolaridade quanto a menor remuneração aparecem em maior porcentagem na cidade de São José dos Campos.

Tabela 15 Distribuição do número de trabalhadores do setor de refeições coletivas segundo tempo de trabalho (meses), no estado de São Paulo em 2017.

\begin{tabular}{|c|c|c|c|c|c|c|c|c|c|c|}
\hline Região Adm SP & Até 5,9 & $\%$ & $\begin{array}{l}6,0 \text { a } \\
23,9\end{array}$ & $\%$ & $\begin{array}{c}24,0 \text { a } \\
59,9\end{array}$ & $\%$ & $\begin{array}{c}60,0 \text { ou } \\
\text { mais }\end{array}$ & $\%$ & Total & $\%$ \\
\hline$\overline{\text { São Paulo }}$ & 9.199 & 23,7 & 13.123 & 33,9 & 10.309 & 26,6 & 6.113 & 15,8 & 38.744 & 100 \\
\hline Campinas & 3.647 & 20,0 & 6.676 & 36,7 & 4.818 & 26,5 & 3.068 & 16,8 & 18.209 & 100 \\
\hline S. J. Campos & 682 & 14,2 & 1.780 & 37,1 & 1.499 & 31,2 & 843 & 17,5 & 4.804 & 100 \\
\hline Sorocaba & 659 & 17,9 & 1.311 & 35,7 & 992 & 27,0 & 713 & 19,4 & 3.675 & 100 \\
\hline Outros & 1.072 & 25,7 & 1.167 & 27,9 & 1.363 & 32,6 & 574 & 13,7 & 4.176 & 100 \\
\hline Total & 15.259 & 21,9 & 24.057 & 34,6 & 18.981 & 27,3 & 11.311 & 16,2 & 69.608 & 100 \\
\hline
\end{tabular}

Fonte: Elaborado pela autora a partir de RAIS (2018). 
No que se refere à duração do vínculo de contratação, a faixa de tempo de trabalho mais frequente é a de 6 a 23,9 meses, 34,6\% dos vínculos. A segunda faixa mais frequente é a 24 a 59,9 meses com $27,3 \%$ dos vínculos. Observa-se que $21,9 \%$ dos trabalhadores possuem seu período de trabalho de até 6 meses. Com tal desenho, pode-se afirmar que os vínculos do setor são predominantemente de curta duração (abaixo de 2 anos). Observa-se comportamento semelhante para todas as cidades, exceto para São José dos Campos e Sorocaba com relação ao tempo de trabalho de até 5,9 meses, que apresenta porcentagens menores que a média das demais cidades, $14,2 \%$ e 17,9\%. Observa-se então que menos trabalhadores se desligam nos primeiros seis meses nas empresas, porém, não permanecem por mais de dois anos.

Em suma, constata-se que o número de vínculos do mercado de refeições coletivas no Brasil diminuiu 7\% de 2015 a 2017, porém no estado de São Paulo aumentou em 0,5\% neste mesmo período. Este setor apresenta-se com uma mão de obra de maioria feminina, sendo $77 \%$ trabalhadores do sexo feminino e $23 \%$ do sexo masculino. A faixa etária predominante dos trabalhadores do setor está entre 25 a 49 anos, $71 \%$. A escolaridade destes trabalhadores apresenta-se em maior número com ensino médio completo. A faixa de remuneração média está entre $\mathrm{R} \$ 1000,00$ e R \$1500,00.

\subsubsection{A Unidade de Alimentação e Nutrição (UAN)}

A Unidade de Alimentação e Nutrição (UAN) tem como objetivo operacionalizar o provimento nutricional de coletividades (Abreu \& Spinelli, 2013). Ela compreende um serviço organizado, destinado a fornecer refeições balanceadas dentro dos padrões higiênicos, atendendo às necessidades nutricionais de seus clientes e se ajustando aos limites financeiros da instituição na qual está inserida. As atividades das UANs também auxiliam na redução de acidentes, taxas de absenteísmo, melhora na aprendizagem, prevenção e manutenção da saúde daqueles que atendem, segundo (Teixeira et al., 2000).

A alimentação coletiva é representada pelas atividades de alimentação e nutrição realizadas nas UANs, que podem ser institucionais, ou seja, aquelas situadas dentro de empresas, escola e outras, cuja demanda é fixa; comerciais, aquelas representadas por restaurantes abertos ao público; hotéis; comidas transportadas ou cozinhas dos estabelecimentos assistenciais de saúde (Abreu e Spinelli, 2013).

Os mesmos autores explicam que as UANs podem estar estabelecidas sob duas formas de gerenciamento, autogestão e concessão. A autogestão ocorre quando a própria 
empresa possui e gerencia a UAN e a concessão advém quando empresa sede seu espaço de produção e/ou distribuição de alimentos para uma empresa de refeições coletivas, terceirizando assim esta atividade da organização. Quanto ao sistema de distribuição de refeições, existem o sistema centralizado, no qual as refeições são produzidas e distribuídas no mesmo local, e o sistema descentralizado, no qual as refeições são produzidas em um local (cozinha central) e distribuídas para outros locais. Podemos encontrar também o sistema misto, em que parte das refeições são distribuídas de forma centralizada e parte, descentralizada. Para esta pesquisa serão estudadas as empresas de refeições coletivas que possuem UANs que prestam serviço de forma terceirizada e utilizando o sistema centralizado.

O setor de refeições coletivas está inserido principalmente no conjunto de empresas terceirizadas. A terceirização significa delegar para e remunerar outra empresa pela execução de uma determinada atividade ou de um conjunto de atividades, que não são parte de sua operação fim. Segundo Araujo e Garcia (2009), quando bem empregada, a terceirização garante às organizações o enxugamento da estrutura do negócio, algo que levou as empresas a focarem no que realmente é fundamental para sua existência no mundo dos negócios.

A UAN é administrada por nutricionistas, profissionais especializados para esta função. Cabem ao nutricionista de UAN as funções de planejamento, organização, direção, supervisão e avaliação, de acordo com os incisos II, VI e VII do artigo $3^{\circ}$; incisos II, IV, IX e X. Parágrafo único do artigo $4^{\circ}$, da Lei no 8.234/91 (Brasil, 1991). Os demais cargos dentro de uma UAN são cozinheiro, responsável pela produção dos alimentos, e auxiliar de cozinha, responsável pelo pré-preparo dos alimentos, distribuição das refeições, higiene dos materiais e ambiente, e organização. No subsetor hospitalar existe também a categoria de trabalho de copeiro hospitalar. Conforme observado por esta pesquisa, descrito adiante, a área de recursos humanos é centralizada nas empresas de refeições coletivas. A gestão de recursos humanos, políticas e práticas, em sua maioria, são estabelecidas pela gerência de RH e operacionalizada pelos nutricionistas nas UANs.

\subsubsection{Sindicatos e negociações coletivas}

O setor de refeições coletivas possui no estado de São Paulo entidades sindicais patronais, que representam as empresas, e entidades sindicais de trabalhadores que, por sua vez, representam os empregados das empresas. 
Os representantes das empresas na grande São Paulo identificados por esta pesquisa foram: Sindicato das empresas de refeições coletivas do Estado de São Paulo (Sinderc) e a Federação Nacional das Empresas de Refeições Coletivas (Fenerc). E os representantes dos empregados da Grande São Paulo foram: o SindiRefeições SP, Sindicato dos trabalhadores em empresas de refeições coletivas da região norte e oeste do estado de São Paulo (Sinterc), Federação dos trabalhadores em empresas de refeições coletivas do estado de São Paulo (Fetercesp) e Sindicato dos empregados nas empresas de refeições coletivas e merenda escolar de Santo André, São Bernardo, São Caetano do Sul, Mauá e Ribeirão Pires (Seerc).

Entre as entidades dos trabalhadores há filiações tanto com a Força Sindical quanto a CUT (Central Única dos Trabalhadores). O sindicato Sindirefeições, Sinterc e Fetercesp são filiados à Força Sindical e o Seerc é filiado ao à CUT. A vigência da Convenção Coletiva de Trabalho ocorre no período de 01 de junho do ano a 31 de maio do ano seguinte e a database da categoria em 01 de junho.

A Convenção Coletiva de trabalho do setor de refeições coletivas, referente a 2018/2019 será apresentada a seguir, sendo descritas as informações mais relevantes à esta pesquisa. A convenção coletiva (CCT, 2019), estabeleceu para as condições salário normativo da categoria profissional reajustado em $2,8 \%$, isto é $\mathrm{R} \$ 1.246,96$ ou $\mathrm{R} \$ 5,67$ por hora (conforme esperado, um valor contido na primeira faixa constante da tabela 12). As empresas poderiam compensar os aumentos ou antecipações no período de 01/06/2017 a 31/05/2018. Definiu-se também salários específicos para cozinheiros de R \$1.386,77 e para copeiro hospitalar de $\mathrm{R} \$ 1.251,41$. A data de pagamento ficou estabelecida até o segundo dia útil bancário, do mês subsequente ao vencido. As empresas que optarem pelo quinto dia útil do mês terão que efetuar adiantamento salarial até o dia vinte do mês, no valor de $30 \%$ do salário percebido pelo empregado. Ficou estabelecido multa de $10 \%$ sobre o saldo salarial, na hipótese de um dia no pagamento de salário e 5\% por dia, do período subsequente. O pagamento do $13^{\circ}$ salário deve ser feito em duas parcelas, sendo a primeira equivalente a $50 \%$ do valor de direito do empregado até o dia 30 de novembro de cada ano e a segunda, os 50\% restantes, até o dia 20 de dezembro de cada ano. Quando houver substituição definitiva, será garantido ao empregado admitido o mesmo salário pago ao que ocupava a mesma função, sem considerar vantagens pessoais. Em substituições eventuais, o substituto fará jus à diferença salarial entre ele o substituído, nas substituições com prazo igual ou superior a 30 dias. Terminada a substituição, deixará de existir a obrigatoriedade do pagamento da referida gratificação por função. Quando houver ocorrência de horas extraordinárias, a remuneração dessas horas deverá ser feita com um adicional de $50 \%$, à 
exceção das horas realizadas nos descansos semanais remunerados, domingos e feriados, que serão remuneradas com adicional de $100 \%$.

Com relação à carga horário de trabalho, as empresas somente poderão implantar seu banco de horas, após acordo coletivo formalizado com o sindicato profissional. O adicional noturno estabelecido é um acréscimo de 35\% sobre a hora diurna. Acerca da PLR, a CCT (2019) estabelece que as empresas deverão apresentar ao sindicato laboral uma proposta de metas e parâmetros para a elaboração da PLR até 30/01/2019.

Os benefícios acordados pela CCT (2019) para o setor de refeições coletivas envolvem o fornecimento de refeições, cujo valor pode ser descontado em $1 \%$ sobre o salário praticado em 2017. A cesta básica ou vale compras é um direito dos empregados com salário nominal igual ou inferior a $\mathrm{R} \$ 5.458,50$, mensalmente e no valor de R $\$ 141,00$. O plano de assistência médica deve ser concedido obrigatoriamente, após 180 dias da admissão e sem carências. As empresas, por meio do sindicato patronal, têm como obrigação recolher das suas expensas mensalmente o valor de $\mathrm{R} \$ 15,00$ por empregado ativo na base territorial do sindicato para auxílio de assistência odontológica, e a categoria profissional e o sindicato se comprometem a oferecer de forma gratuita assistência odontológica a todos estes empregados. As empresas que não possuírem creche própria ou contratada, reembolsarão para o empregado com guarda comprovada do menor de até 6 anos, o valor limitado a $30 \%$ do salário normativo, para aqueles que recebem até 1,5 do piso. Todo empregado ativo tem direito a seguro de vida e/ou acidentes pessoais no valor de $\mathrm{R} \$ 20.000,00$.

Sobre os contratos de trabalho, a CCT (2019) define que as rescisões de contrato de trabalho, com tempo de serviço igual ou superior a 12 meses, deverão ser preferencialmente homologadas no sindicato. Considera-se trabalho em regime de tempo parcial aquele cuja duração não exceda 30 horas semanais, sem possibilidades de horas suplementares, ou aquela cuja duração não exceda a 26 horas semanais, com a possibilidade de acréscimo de até 6 horas suplementares e o salário a ser pago será proporcional à sua jornada, em relação aos empregados que cumprem tempo integral. A realização de acordo mútuo, previsto no artigo 484, só poderá ocorrer mediante assistência do sindicato. O contrato de trabalho intermitente é considerado quando há alternância de períodos de prestação de serviços e de inatividade, determinados em horas, dias ou meses, somente para atividades eventuais. Este tipo de contrato somente poderá ser celebrado para novas contratações e a remuneração não poderá ser inferior ao salário pago para os demais empregados que exerçam a mesma função e terão direito a vale transporte e vale refeição e/ou refeição no local de trabalho. Quando o trabalho for igual ou superior a quinze dias, os trabalhadores terão direito a cesta básica e 
não será obrigatório o fornecimento de convênio médico. A redução do intervalo intrajornada só terá validade mediante acordo coletivo, aprovado em assembleia. Em caso de descumprimento de qualquer cláusula da convenção coletiva, deve-se pagar $30 \%$ sobre o piso normativo do empregado prejudicado (CCT, 2019).

Tabela 16 Principais cláusulas da Convenção Coletiva 2018/2019 do setor de refeições coletivas.

\section{Cláusulas}

Salário normativo da categoria profissional reajustado em $2,8 \%$, isto é $\mathrm{R} \$ 1.246,96$ ou $\mathrm{R} \$ 5,67$ por hora

As empresas deverão apresentar ao sindicato laboral uma proposta de metas e parâmetros para a elaboração da PLR até 30/01/2019.

As rescisões de contrato de trabalho, com tempo de serviço igual ou superior a 12 meses, deverão ser preferencialmente homologadas no sindicato.

Considera-se trabalho em regime de tempo parcial aquele cuja duração não exceda 30 horas semanais, sem possibilidades de horas suplementares, ou aquela cuja duração não exceda a 26 horas semanais, com a possibilidade de acréscimo de até 6 horas suplementares e o salário a ser pago será proporcional à sua jornada, em relação aos empregados que cumprem tempo integral.

A realização de acordo mútuo, previsto no artigo 484, só poderá ocorrer mediante assistência do sindicato.

O contrato de trabalho intermitente é considerado quando há alternância de períodos de prestação de serviços e de inatividade, determinados em horas, dias ou meses, somente para atividades eventuais. Este tipo de contrato somente poderá ser celebrado para novas contratações e a remuneração não poderá ser inferior ao salário pago para os demais empregados que exerçam a mesma função e terão direito a vale transporte e vale refeição e/ou refeição no local de trabalho.

A redução do intervalo intrajornada só terá validade mediante acordo coletivo, aprovado em assembleia.

Fonte: Adaptado de CCT (2019).

As cláusulas da convenção coletiva de 2019, que estão relacionadas às questões de GERH e relações de trabalho e que serão discutidas adiante, estão apresentadas na tabela 15. O salário base da categoria está estabelecido em R\$ 1.246,96, valor que é apresentado na tabela 13 como sendo a remuneração de $53 \%$ dos trabalhadores do setor no estado de São Paulo. A cláusula de estabelecimento de data para definição da PLR, demonstra um dos pontos a serem negociados nos acordos coletivos entre sindicato dos trabalhadores e empresas. A homologação das rescisões devem continuar sendo realizadas nos sindicatos, mesmo com a não obrigatoriedade estabelecida na Reforma Trabalhista, projeto de lei PL 6.787/2016, apresentado anteriormente no subcapítulo 2.1.3. Outras modificações 
estabelecidas pela Reforma Trabalhista como a regulamentação de contratos de trabalho em regime de tempo parcial, contrato intermitente e a possibilidade da redução do trabalho intrajornada estão estabelecidos nesta Convenção Coletiva de Trabalho 2018/2019.

\subsection{Descrição das organizações estudadas}

A Empresa Alpha foi fundada em meados de 1990 na França e hoje é líder mundial em Serviços de Qualidade de Vida, conforme site da Empresa Alpha. A organização opera em 80 países e é a $18^{\mathrm{a}}$ maior empregadora mundial, com 428.000 colaboradores. O direcionamento da empresa na indústria de serviços é de integrar diversos serviços para melhorar a qualidade de vida daqueles que servem, contribuindo para o desempenho e progresso da empresa cliente. Atua no Brasil há 40 anos. O seu posicionamento estratégico é ser sempre uma empresa de serviços e permanecer independente. A independência da organização é garantida através de um controle familiar de participação por uma holding, que detém $37,7 \%$ do capital e $47,6 \%$ dos direitos de voto. A independência financeira também parte de dois pressupostos, atividades com baixa intensidade de capital e baixo investimento médio, que representam $2 \%$ da receita e acesso permanente a recursos financeiros suficientes para financiar desenvolvimento, reembolsar empréstimos de médio prazo e repassar dividendos aos acionistas. A ambição da empresa é impulsionar o desenvolvimento dos seus colaboradores e a médio prazo estar entre as multinacionais mais valorizadas por seus empregados, fazer da organização uma marca conhecida, escolhida e admirada mundialmente e manter a média anual de crescimento de receita em 7\%. A história da Empresa Alpha, conforme site da empresa, inicia-se em 1978 com a inauguração do primeiro escritório, em São Paulo. Em 1980, inaugura escritório no Rio de Janeiro e inicia suas operações em uma indústria de papel. Em 1983, passa a atuar no segmento petrolífero. Em 1992, adquire uma empresa de refeições coletivas e a companhia duplica de tamanho. Entre 1995 e 1999 adquire duas empresas de alimentação em São Paulo e passa a atender o mercado de educação e saúde. Em 1996 inaugura escritório em Minas Gerais e Paraná, e em 1998 inaugura escritório no Nordeste. No ano de 2000, adquire mais uma Empresa de refeições coletivas em São Paulo e em 2004 inicia as atividades em uma mineradora. Em 2005 inaugura escritório em Porto Alegre (RS), em 2007 inicia as atividades em uma grande indústria de insumos e em 2011 adquire uma Empresa de refeições coletivas situada em Porto Alegre (RS), com 30 anos no mercado, 1 milhão de refeições/dia, em mais de 1.000 unidades e 22 mil colaboradores. 
A Empresa Alpha possui 40.000 empregados no Brasil, sendo 25.000 localizados no estado de São Paulo. No departamento de RH existem 120 pessoas. A organização possui por escrito a missão, a estratégia do negócio e a estratégia de RH. A missão da empresa é "melhorar a qualidade de vida de todas as pessoas a quem servimos e contribuir com o desenvolvimento econômico, social e ambiental das comunidades, regiões e países em que atuamos" (site Alpha). Os valores da empresa são definidos como espírito de serviço, espírito de equipe e espírito de progresso. Existem também princípios éticos bem definidos como lealdade, respeito às pessoas, transparência e integridade comercial. $\mathrm{O}$ crescimento profissional é um objetivo da Empresa Alpha, pois, segundo seu site, $80 \%$ dos gestores foram promovidos internamente. Os colaboradores são incentivados a aprender ao longo de sua vida profissional, com o propósito de fortalecer a empregabilidade dos funcionários. Em 2010, 81\% dos trabalhadores se beneficiaram de cursos de atualização.

Os responsáveis pelas decisões políticas da Empresa Alpha sobre recrutamento e seleção, treinamento e desenvolvimento, relações de trabalho e expansão e redução da força de trabalho são um coordenador de RH, um gerente de RH e um vice-presidente de RH. Estas três posições tomam as decisões políticas de RH porque

\footnotetext{
“a Empresa Alpha tem como princípio que a decisão não cabe a uma pessoa só, a estratégia permeia toda a organização, isso é muito fincado dentro dela, e acontece na prática, porque você escreve, você divulga, e você tem a participação de todos para que isso aconteça" (Ent.Alpha).
}

A proporção de empregados associados aos sindicatos é de 50\%. A Empresa Alpha é uma organização multinacional e sua sede está baseada na França. O mercado principal para os serviços que a Empresa Alpha oferece é mundial. Para o entrevistado o mercado de refeições coletivas está crescendo.

A Empresa Beta faz parte de um grupo que possui no mundo 550.000 empregados e está presente em mais de 50 países (site Beta). No Brasil possuem 30.000 colaboradores e 10.000 no estado de São Paulo. A Empresa Beta atua no Brasil há mais de 40 anos. Sua produção por dia está em mais de 1 milhão de refeições. Seus clientes abrangem os setores industriais, escolas, hospitais, terminais de passageiros, espaços de eventos e entretenimento, plataformas de petróleo e locais remotos (site Beta). A história da Empresa Beta começou em 1977 no Brasil, inicialmente fundada por um grupo da rede hoteleira. Em 1979 a empresa já possuía 30.000 consumidores. Expandiu seus negócios na década de 80 com sete filiais 
regionais. Em 1997 a organização adquiriu uma Empresa de refeições coletivas. Em 1998 o grupo atual proprietário da empresa, adquiriu 50\% da organização. Em 2000 a Empresa Beta adquiriu duas organizações de refeições coletivas. Em 2003 o modelo de gestão da empresa passou a ser centralizado e foi inaugurada uma nova sede em São Paulo. Em 2008 o grupo adquiriu 100\% da empresa. Em 2010 conquistou as certificações ISO 9001, ISSO 14001 e OSHAS 18001.

O código de conduta nos negócios e código de ética está estabelecido e registrado. A visão apresentada pela Empresa Beta é "Ser um fornecedor de classe mundial em serviços de alimentação e de suporte, assegurado pela nossa melhor equipe, nosso melhor serviço e nosso melhor resultado" (site Beta). A missão definida pela organização é "Estamos comprometidos em prestar serviços com excelência de forma consistente e eficiente, gerando benefícios para clientes, consumidores, colaboradores, acionistas e fornecedores" (site Beta). Os princípios orientadores da empresa são: segurança, saúde e meio ambiente em primeiro lugar; entregar resultados para clientes e consumidores; desenvolver nossas pessoas, valorizando a diversidade; crescimento rentável e foco constante no desempenho e eficiência. Os valores são: abertura, confiança e integridade; paixão pela qualidade; sucesso através do trabalho em equipe; responsabilidade e dinamismo. Com relação aos colaboradores, a Empresa Beta possui, em seus quatro pilares estabelecidos, um que visa garantir que os funcionários sejam bem treinados, motivados e produtivos, “. . . sendo uma parte essencial do nosso modelo de negócio" (site Beta).

Conforme Ent.Beta, a proporção etária da força de trabalho é de $40 \%$ possui de 25 a 49 anos, $30 \%$ de 18 a 24 anos e $30 \%$ de 50 anos ou mais. Semelhantes resultados foram encontrados na base de dados RAIS apresentados na tabela 10. A proporção da força de trabalho é de $7 \%$ de gerentes, $9 \%$ de profissionais sem responsabilidade gerencial e $84 \%$ de administrativos e operacionais. O RH da Empresa Beta possui 45 pessoas e a organização possui por escrito a missão que é "Nutrir, Cuidar e Crescer" (site Beta), a estratégia do negócio e a estratégia de RH. Os responsáveis pelas decisões políticas de recrutamento e seleção são o gerente e diretora de $\mathrm{RH}$, de relações do trabalho e expansão e redução da força de trabalho é o diretor de RH. A empresa possui $15 \%$ de empregados associados aos sindicatos. A taxa de absenteísmo declarada pelo entrevistado da Empresa Beta é de 10\%. A empresa é multinacional com sede na Inglaterra. As políticas de RH são determinadas na Inglaterra e adaptadas aos demais países, porém as áreas podem criar políticas e encaminhar para aprovação da sede. Para Ent.Beta, o mercado de refeições coletivas está em declínio, “. 
. um dos motivos é o encerramento mesmo dos postos de trabalho e também o início da utilização de ferramentas de trabalho remotas." (Ent.Beta).

A Empresa Gamma foi fundada em meados de 1990 e estabeleceu-se como multinacional brasileira de restaurantes de refeições coletivas, atuando também no México e Colômbia (site Gamma). A história da empresa iniciou-se em Campinas, servindo 250 refeições para uma Empresa de fios para pesca e afins. Ao longo de sua história, aprimorou seus processos e conquistou diversos prêmios e reconhecimentos como Prêmio QualitasFiat, "500 melhores e maiores empresas no Brasil”" no guia Exame, "Empresa Revelação do ano" no Troféu Melhores Fornecedores de RH da revista Gestão RH, dentre outros. A organização possui definida a cultura da empresa: "Gerar e capturar valor todos os dias, criando experiências memoráveis e qualidade de vida nos espaços da empresa", a política de qualidade: "Buscar constantemente encantar nossos clientes por meio do contínuo aperfeiçoamento dos serviços e manter a comunicação aberta e transparente, proporcionando relações comerciais saudáveis e duradouras", e a política de meio ambiente, saúde e segurança no trabalho: "Atuar de forma preventiva na proteção do ser humano e do meio ambiente, atender a legislação e outros requisitos aplicáveis nas áreas de meio ambiente saúde e segurança, comprometendo-se com a melhoria contínua dos resultados do Sistema de Gestão" (site Gamma).

O número de funcionários no Brasil é de 15.000, são 6.500 empregados no estado de São Paulo, ela produz 1,3 milhões de refeições por dia e possui 900 clientes (site Gamma). A proporção etária da força de trabalho é de $5 \%$ de 18 a 24 anos, $75 \%$ de 25 a 49 anos e $20 \%$ de 50 anos ou mais. Observa-se mais uma vez a mesma proporção etária que a apresentada pela RAIS na tabela 10 . A proporção da força de trabalho é de $20 \%$ gerentes, profissionais sem responsabilidade gerencial $10 \%$ e administrativos e/ou operacionais $70 \%$. O departamento de RH possui 45 colaboradores. A organização possui por escrito a sua missão, "Inovar no dia a dia de nossos clientes e consumidores, trazendo experiências em alimentação de qualidade de forma saudável, segura e sustentável. Fazendo diferente, sempre, para fazer a diferença"; visão, "Buscar sempre a liderança e reconhecimento no mercado de alimentação, atuando de forma íntegra e ética sendo incansável na busca pela excelência de nossos serviços" (site Gamma); e estratégia do negócio e estratégia de RH. Os valores da empresa são: qualidade de produtos e serviços, trabalho em equipe, qualidade de vida, desenvolvimento humano, relações de confiança, saudáveis e duradouras, criatividade, inovação e evolução tecnológica, sustentabilidade, integridade, ética e transparência (site Gamma). O código de ética da empresa está registrado e divulgado em seu site. 
$\mathrm{Na}$ Empresa Gamma, os responsáveis pelas decisões políticas de RH como recrutamento e seleção e treinamento e desenvolvimento são o coordenador e diretor de RH, sobre relações de trabalho é o diretor de $\mathrm{RH}$ e a área jurídica da empresa e sobre expansão e redução da força de trabalho é o diretor operacional e a controladoria da organização. A proporção de empregados associados aos sindicatos é de $20 \%$. A porcentagem de rotatividade é de 2,5\%. A Empresa Gamma é uma organização nacional, sediada no Brasil. As políticas de RH são determinadas pelo comitê executivo. Para Ent.Gamma, o mercado de refeições coletivas está crescendo.

A Empresa Delta foi fundada em meados dos anos 1970 no Brasil, sendo o primeiro cliente a Secretaria de Segurança Pública do Estado de São Paulo, produzindo e transportando refeições às cadeias públicas do Grande ABC. Em 2001 inaugura filiais no Rio de Janeiro e Goiânia atendendo empresas de grande porte e secretarias de governos locais. Em 2003 ocorre a abertura da filial Brasília no Distrito Federal, atendendo o Supremo Tribunal Federal e em 2004 abriu a filial Campo Grande no Mato Grosso do Sul. Em 2005 inaugura a filial em Mongaguá, no litoral sul de São Paulo, implantando o fornecimento de alimentação escolar e em 2007 expandiu seus negócios em Minas Gerais e Rio Grande do Sul. Em 2010 recebeu as certificações ISSO 9001, ISSO 14001 e OHSAS 18001, formando assim um sistema de gestão integrado.

Atualmente, a Empresa Delta possui 678 funcionários no Brasil e 355 no estado de São Paulo. A proporção etária da força de trabalho é de 15\% de 18 a 24 anos, $68 \%$ de 25 a 49 anos e 17\% com mais de 50 anos de idade. Estes dados também se assemelham aos apresentados pela base de dados da RAIS na tabela 10. A proporção da força de trabalho é $3 \%$ gerentes, $10 \%$ profissionais sem responsabilidade gerencial e $87 \%$ administrativos e/ou operacionais. O departamento de RH possui 8 pessoas. A organização possui por escrito a missão "Fornecer aos nossos clientes serviços e produtos de alimentação, dentro de um padrão alimentar mais saudável, proporcionando prazer ao consumi-los e colaborando para melhorar sua qualidade de vida e do ambiente, atuando com responsabilidade social" (site Delta) e estratégia de negócio da empresa, porém não está registrado a estratégia de $\mathrm{RH}$, apesar de ser definida, "a nossa estratégia de RH é atender o nosso funcionário de forma simples, clara e objetiva" (Ent.Delta). O responsável pelas decisões políticas de recrutamento e seleção, treinamento e desenvolvimento e relações de trabalho é o gerente de $\mathrm{RH}$, sobre a expansão e redução da força de trabalho é o gerente de RH e a diretoria da empresa. A proporção de empregados associados aos sindicatos é 19\%. A porcentagem de rotatividade da Empresa Delta é de 6\% e de absenteísmo é de 2,43\%. A organização é 
nacional brasileira com sede em São Paulo. As políticas de RH são determinadas pelo RH em São Paulo. O mercado para os serviços da Empresa Delta é nacional e segundo o entrevistado, é um mercado que está diminuindo porque muitos órgãos públicos estão produzindo suas refeições.

Tabela 17 Síntese das descrições das empresas de refeições coletivas entrevistadas.

\begin{tabular}{|c|c|c|c|c|c|}
\hline \multicolumn{2}{|c|}{ Característica } & $\begin{array}{c}\text { Empresa } \\
\text { Alpha }\end{array}$ & Empresa Beta & $\begin{array}{l}\text { Empresa } \\
\text { Gamma }\end{array}$ & $\begin{array}{c}\text { Empresa } \\
\text { Delta }\end{array}$ \\
\hline \multicolumn{2}{|l|}{$\begin{array}{l}\text { No de empregados no } \\
\text { estado de São Paulo }\end{array}$} & 25.000 & 10.000 & 6.500 & 355 \\
\hline \multirow{3}{*}{$\begin{array}{l}\text { Proporção etária da } \\
\text { força de trabalho }\end{array}$} & 18 a 24 anos & \multirow{3}{*}{$\begin{array}{l}\text { Não } \\
\text { respondeu }\end{array}$} & $30 \%$ & $5 \%$ & $15 \%$ \\
\hline & 25 a 49 anos & & $40 \%$ & $75 \%$ & $68 \%$ \\
\hline & 50 anos ou mais & & $30 \%$ & $25 \%$ & $17 \%$ \\
\hline \multicolumn{2}{|l|}{$\begin{array}{l}\text { Proporção da força de } \\
\text { trabalho operacional }\end{array}$} & $\begin{array}{l}\text { Não } \\
\text { respondeu }\end{array}$ & $84 \%$ & $\begin{array}{l}\text { Não } \\
\text { respondeu }\end{array}$ & $87 \%$ \\
\hline \multicolumn{2}{|l|}{ No de pessoas no RH } & 120 & 45 & 45 & 8 \\
\hline \multicolumn{2}{|l|}{$\begin{array}{l}\text { Existência de } \\
\text { estratégia de RH por } \\
\text { escrito }\end{array}$} & Sim & Sim & Sim & Não \\
\hline \multicolumn{2}{|l|}{$\begin{array}{l}\text { Proporção de } \\
\text { empregados } \\
\text { sindicalizados }\end{array}$} & $50 \%$ & $15 \%$ & $20 \%$ & $19 \%$ \\
\hline \multirow{2}{*}{$\begin{array}{l}\text { Porcentagem de } \\
\text { rotatividade e } \\
\text { absenteísmo }\end{array}$} & Rotatividade & \multirow{2}{*}{$\begin{array}{l}\text { Não } \\
\text { respondeu }\end{array}$} & $40 \%$ & $2,5 \%$ & $6 \%$ \\
\hline & Absenteísmo & & $10 \%$ & $\begin{array}{l}\text { Não } \\
\text { respondeu }\end{array}$ & $2,4 \%$ \\
\hline \multicolumn{2}{|l|}{$\begin{array}{l}\text { Responsáveis por } \\
\text { decisões políticas de } \\
\text { RH }\end{array}$} & $\begin{array}{l}\text { Vice- } \\
\text { presidente de } \\
\text { RH e gerente } \\
\text { de RH }\end{array}$ & $\begin{array}{l}\text { Diretor de RH } \\
\text { e gerente de } \\
\text { RH }\end{array}$ & $\begin{array}{c}\text { Diretor de } \\
\text { RH, } \\
\text { coordenador } \\
\text { de RH e área } \\
\text { jurídica } \\
\end{array}$ & $\begin{array}{c}\text { Diretoria da } \\
\text { empresa e } \\
\text { gerente de } \mathrm{RH}\end{array}$ \\
\hline \multicolumn{2}{|l|}{$\begin{array}{l}\text { Nacional ou } \\
\text { multinacional }\end{array}$} & Multinacional & Multinacional & Multinacional & Nacional \\
\hline \multicolumn{2}{|l|}{ País sede } & França & Inglaterra & Brasil & Brasil \\
\hline \multicolumn{2}{|l|}{ Situação do mercado } & Crescendo & Diminuindo & Crescendo & Diminuindo \\
\hline
\end{tabular}

Fonte: Elaboração da autora.

A faixa etária com maior número de empregados está entre 25 a 49 anos, semelhante resultado encontramos na base de dados da RAIS apresentada na tabela 10 . Cerca de $85 \%$ da força de trabalho está em atuação operacional. O registro documental das estratégias de RH é declarado em três empresas, Alpha, Beta e Gamma. Observa-se também que os gestores de RH das quatro empresas estão envolvidos nas decisões políticas de RH. A taxa de sindicalização é apontada pelas empresas e pelos sindicatos em valores diferentes. Para a 
Empresa Alpha a taxa é de 50\%, Empresa Beta 15\%, e Empresa Gamma 20\%. Três das empresas estudadas são multinacionais e uma nacional. Duas empresas possuem sua sede em país estrangeiro e as outras duas com sede no Brasil. Constatou-se uma diferença na percepção do mercado pelas empresas, dois gestores declararam que o mercado está crescendo e dois que está diminuindo. Verificou-se que a percepção de diminuição está relacionada com o comportamento da própria empresa em que o entrevistado atua e não do mercado como um todo, conforme as declarações, "um dos motivos é o encerramento mesmo dos postos de trabalho e também o início da utilização de ferramentas de trabalho remotas." (Ent.Beta), a empresa “Está diminuindo, porque muitos órgãos públicos estão internalizando a confecção das refeições" (Ent.Delta).

4.3 O RH e as relações de trabalho nas empresas estudadas

Neste subcapítulo, apresenta-se o relato dos entrevistados das empresas estudadas e dados dos seus respectivos sites sobre as práticas e políticas de $\mathrm{RH}$, e como se conduzem as relações de trabalho entre empresa, sindicatos e funcionários.

\subsubsection{Empresa Alpha}

Segundo o entrevistado da Empresa Alpha, o vice-presidente de RH participa do comitê executivo da empresa e possui voz ativa nas questões estratégicas. A influência que os sindicatos possuem na organização proporciona uma boa relação que é necessária para os dois lados, colaborando com a transparência e atenção no cuidado com os colaboradores. Os sindicatos dos empregados possuem ação direta nas negociações de PLR e banco de horas. Estes realizam assembleias junto aos trabalhadores, definindo quais exigências e acordos serão colocados em pauta nas negociações com a empresa. Existe uma negociação de acordos coletivos descentralizada com os sindicatos, sendo necessário contato com cada um deles. Sendo assim a duração das negociações de acordos coletivos para a empresa podem se estender por até quatro meses.

Os acordos coletivos das empresas são negociados pela Empresa Alpha com os respectivos sindicatos das regiões em que atua. A Empresa Alpha realiza acordos coletivos com 112 sindicatos no Brasil. Estas negociações de acordos coletivos ocorrem de fevereiro até junho e julho. O profissional responsável por estas negociações é um coordenador de relações sindicais. 
A única negociação que acontece em conjunto é a que ocorre no estado de São Paulo, porque os sindicatos dos trabalhadores são conduzidos por uma federação. Estabelece-se uma pauta de reivindicações dos sindicatos dos trabalhadores, que é apresentada para o sindicato patronal e inicia-se a negociação. Da mesma forma do sindicato dos empregados ocorre com o sindicato patronal, ouve-se as empresas, publica-se um edital, realiza-se a assembleia e uma comissão das empresas é eleita. Esta comissão é composta por cinco ou seis membros, que realizam as negociações com os sindicatos.

Os sindicatos dos trabalhadores não participam do comitê executivo da organização. Isto ocorre porque a empresa precisa negociar com diversos sindicatos, então seria muito difícil eleger um único sindicato para fazer essa representação. A participação de todos os sindicatos seria inviável, pois a organização possui 112 sindicatos vinculados à organização. Poderia gerar também um problema político entre os sindicatos, cada um tem seu espaço e são tratados de forma igual independentemente do tamanho.

As comissões de trabalhadores não existem na Empresa Alpha. Segundo o entrevistado, existem sindicatos de trabalhadores que incentivam esta prática, porém vinculando a comissão ao próprio sindicato, não como uma organização de trabalhadores independente. Os trabalhadores podem manifestar para a empresa suas ideias e reclamações através de alguns canais de comunicação e existe um comitê de ética. Este canal é direto com todos os trabalhadores do Brasil inteiro.

A participação do RH em mudanças existe, pois “. . . tem voz bastante atuante nessa questão" (Ent.Alpha). Houve uma aquisição em 2011, que dobrou o tamanho da empresa e a participação do RH sempre ocorreu em aquisições.

A respeito da reforma trabalhista, os sindicatos dos trabalhadores entenderam que precisam ir mais ao local de trabalho e estar mais próximo aos empregados. "Porque se não fizerem isso o empregado não dará a valorização que eles efetivamente precisam ter . . . Os sindicatos estão mais cuidadosos diante destas mudanças . . . Solicitações de visitas antes não requeridas, começaram a surgir" (Ent.Alpha). Portanto, para o entrevistado Alpha, a reforma trouxe um desempenho mais ativo dos sindicatos dos trabalhadores, sendo isto um ponto importante para ele.

\subsubsection{Empresa Beta}

A participação de um responsável de RH no comitê executivo da empresa não ocorre, conforme conhecimento da entrevistada. A interação entre os sindicatos e a empresa é maior 
que a influência entre as partes. "Não é uma influência, mas sim interação" (Ent.Beta). Esta interação ocorre por causa das relações do trabalho e negociações dos acordos coletivos. Existem negociações diferenciadas devido à diferentes realidades por causa dos clientes aonde as UANs estão inseridas. O contato do RH com os sindicatos ocorre constantemente através de telefone, Whatsapp e e-mail.

As negociações de acordos coletivos são realizadas por um profissional especialista em relações de trabalho, o qual possui o cargo de coordenadora de relações de trabalho. Os acordos são realizados individualmente com cada sindicato. $\mathrm{O}$ acordo coletivo para banco de horas é igual para todos os sindicatos, porém para os acordos de PLR existem algumas particularidades dependendo do setor ao qual o cliente está inserido, como o dos metalúrgicos que influenciam nos valores das negociações das empresas terceiras.

Não existe a participação dos sindicatos no comitê executivo da Empresa Beta, porque os objetivos das partes são diferentes. "As centrais sindicais também não saberiam como se viabilizar, porque realmente são lados opostos, não seria possível juntá-los" (Ent.Beta). As comissões de trabalhadores também não estão presentes na organização, somente a CIPA, que é obrigatória por lei. Isto ocorre porque as UANs estão geograficamente separadas e não há interesse dos trabalhadores em assumir este tipo de responsabilidade. "Ninguém quer essa responsabilidade porque todo mundo reclamará de tudo e a pessoa pode se perder no dia a dia" (Ent.Beta).

A comunicação dos trabalhadores para expressar suas reclamações e ideias é realizada através de uma ferramenta denominada Speak Up. O funcionário entra em contato telefônico por um número de 0800 gratuito ou através de e-mail, realiza-se a denúncia ou sugestão. Relata-se algumas informações essenciais para fazer a localização, e inicia-se o tratamento da solicitação. A sede localizada em Londres acompanha o desfecho dos casos e existe um prazo para que o processo se encerre. Após decididas as ações a serem tomadas, comunica-se ao business partner e ao gerente de operações, a fim de orientar o gestor do local para atuar na resolução do assunto.

Não ocorreram mudanças nos últimos três anos como aquisição, venda, fusão e etc. Porém, segundo a entrevistada, não há participação do RH nestes momentos, mas sim da área comercial. Se durante o processo há alguma dúvida sobre pessoas, consulta-se a área de RH, mas não é uma consulta obrigatória para a tomada de decisão. Após decidida a mudança as demais áreas são comunicadas. “. . . na Empresa Beta, acontece que quando é fechado o contrato, é feita uma reunião de passagem, e as áreas entram no circuito, porém, não é prévia, é a posteriori do contrato dentro de casa" (Ent.Beta). 
A reforma trabalhista resultou em algumas vitórias para as empresas, porém como entidade patronal e não como empresas isoladamente, conseguiu-se algumas conquistas de aplicação da nova legislação, como negociação de alguns pontos, como flexibilização de intervalos, podendo ser reduzidos ou fracionados e, como o processo de homologação, podendo ser realizado pelo próprio gerente da UAN. Observam-se estes pontos na convenção coletiva 2018/2019, nas cláusulas apresentadas da tabela 15, porém as homologações somente poderão ser realizadas pela empresa quando o tempo de serviço for menor que 12 meses, caso contrário deve ser realizado preferencialmente nos sindicatos dos trabalhadores (CCT, 2019). Os sindicatos dos trabalhadores do estado de São Paulo, que são estruturados e sempre buscaram aproximação com os trabalhadores, continuam com grande parte das pessoas de sua base a ele associadas, contudo, os sindicatos menos ativos estão sofrendo impacto na quantidade de associados. “. . . os mais ausentes e relapsos estão passando por mais dificuldade de associação" (Ent.Beta).

\subsubsection{Empresa Gamma}

Existe a participação do diretor de RH no comitê executivo, porém a percepção do entrevistado é que o RH não participa de decisões estratégicas. "Com a estratégia ele não se envolve. Não sei o porquê" (Ent.Gamma). Verifica-se uma interferência ou intervenção direta por parte do sindicato do cliente e do sindicato do setor refeições coletivas. Quando uma UAN está localizada em uma indústria que faz parte de um setor mais ativo, como os metalúrgicos, por exemplo, há influência nos demais sindicatos das empresas que prestam seus serviços, para que as negociações e benefícios conquistados pelos funcionários não estejam muito distantes entre si, mesmo sendo setores diferentes. "O sindicato do ABC, onde eles estão mais focados em fazer o atendimento, em estarem próximos aos trabalhadores e filiados à CUT, é bastante complicado. Os trabalhadores metalúrgicos, ficam na área operacional e alguns interferem nos terceiros, como no restaurante" (Ent.Gamma).

O RH tem contato constante com o sindicato dos trabalhadores, para resolução de qualquer intercorrência. Para a organização isso é bom, porque possui um interlocutor entre empresa e sindicato.

"por exemplo, ontem foi dia de pagamento e houve um desconto da participação do trabalhador errado no convênio médico, e quem cuida disso? É a pessoa de folha, ou de benefício? . . É feita uma ligação 
indicando o problema e eu já vou diretamente falar com a pessoa, se é da folha, se é de benefícios, e o retorno que se tem sobre as providências que a empresa tomará é muito mais rápido" (Ent.Gamma).

O responsável pela interação entre a Empresa Gamma e os sindicatos é um consultor, exgerente de RH da Empresa Gamma e possui especialização em relações de trabalho.

As condições de trabalho entre empresa e sindicato dos trabalhadores são estabelecidas na convenção coletiva do setor e os acordos coletivos como banco de horas e PLR, são tratados pela Empresa Gamma cada sindicato de trabalhadores. Não há participação dos sindicatos de trabalhadores no comitê executivo e nas decisões da empresa porque para o entrevistado são focos diferentes. O sindicato está muito direcionado a buscar benefícios e condições melhores de trabalho para o empregado, e o comitê executivo está focado na parte estratégica da empresa. "Trabalho de um lado, capital do outro" (Ent.Gamma).

Uma comissão de trabalhadores não se observa na Empresa Gamma, todavia em unidades grandes, com duzentos ou trezentos funcionários, existe um representante que atua como um interlocutor, autodenominado como parte de uma comissão, “. . . mas é só de fato, não é de direito" (Ent.Gamma). Esta comissão assim nomeada pelos trabalhadores, atua somente para facilitar a comunicação dos empregados de grandes unidades de alimentação com a empresa, porém, ela é observada como uma situação informal, não reconhecida pela organização Gamma. A comunicação dos empregados com a empresa ocorre através de um canal aberto, gerenciado por uma Empresa de auditoria externa e é tratado internamente com um comitê formado por uma parte jurídica, de RH e de operações, com todo sigilo. Observase em seu site um link que apresenta número de telefone, endereço de página eletrônica, número de caixa postal e e-mail para ser utilizado por colaboradores, clientes e fornecedores como meios para apontamento de condutas que descumpram o código de ética da empresa, como corrupção, racismo, assédio moral e sexual.

Nos últimos três anos não ocorreram mudanças estratégicas, mas o RH não é envolvido em situações semelhantes, mas sim a área comercial e de operações.

\footnotetext{
“Um exemplo, para fazer mil refeições o comercial acha que dá para fazer com vinte, e a operação fala que precisa de vinte e cinco, o comercial acha que é possível fazer por um valor e a operação diz que não dá, que naquelas condições ela não conseguirá trazer o resultado para a empresa" (Ent.Gamma).
} 
Após estas duas áreas decidirem sobre o contrato, as áreas de apoio são comunicadas, como o RH para fazer as contratações, para desenvolver fornecedor de benefícios e etc. Contudo, no momento da decisão estratégica da empresa, o RH não participa. A reforma trabalhista, de acordo com o entrevistado Gamma, foi muito pouco aplicável para o setor de refeições coletivas. Houve contribuições bastante significativas para operação e para o resultado da empresa e até mesmo para a satisfação do próprio trabalhador, como a flexibilização da hora de almoço, reduzindo a jornada de trabalho em meia hora. Nas cláusulas da Convenção Coletiva 2018/2019 apresentadas na tabela 15, contata-se este acordo de possível redução do intervalo intrajornada.

\subsubsection{Empresa Delta}

O gerente de RH participa do comitê executivo uma vez por mês em uma reunião de fechamento, momento em que se tomam muitas decisões. Os sindicatos influenciam a organização através das convenções coletivas. "Hoje a convenção coletiva possui sessenta ou setenta cláusulas, então, existe uma influência" (Ent.Delta). Existe um bom relacionamento com todos os sindicatos dos trabalhadores, pois demonstram coerência em suas ações. O contato do RH com os sindicatos ocorre constantemente desde muitos anos, principalmente para os acordos coletivos. Para casos específicos também há contato entre as partes, como reclamações por exemplo, os sindicatos se comunicam com o RH, verifica-se o problema e retorna-se com a solução.

O gerente de RH é o responsável pelas negociações com os sindicatos. Os acordos coletivos como PLR e banco de horas ocorrem com cada sindicato. A PLR negocia-se em abril e acordo de banco de horas em junho, podendo variar um pouco com sindicato. As negociações podem durar um mês. Aproximadamente a empresa negocia com trinta sindicatos diferentes em todo o Brasil.

A participação dos sindicatos no comitê executivo não existe "Porque não é necessário, o sindicato precisa saber da Empresa Alpha aquilo que ele de fato necessita saber" (Ent.Delta). Por exemplo, quando são comunicados sobre algum assunto relacionado a alguma questão presente na convenção coletiva. Reduções de número de funcionários somente são comunicadas ao sindicato porque devem realizar as homologações nos sindicatos, “. . . não existe uma política da Empresa de informar tudo ao sindicato" (Ent.Delta). 
A organização não possui comissão de trabalhadores, porém existem canais de para comunicação de suas ideias e reclamações. As formas de comunicação são telefone e e-mail, e não é necessário identificar-se, conforme regulamento interno. Há um regulamento para qualquer tipo de reclamação ou denúncia, como corrupção, racismo, maus-tratos e sobre conduta antiética do encarregado. $\mathrm{O}$ contato direto com o RH também existe, as pessoas podem conversar com o pessoal de atendimento sobre situações como folha de pagamento ou segurança do trabalho. “. . . a empresa de cultura familiar é muito aberta, então, aqui eles têm liberdade para conversar com quem eles quiserem" (Ent.Delta).

Não ocorreram mudanças na Empresa durante os últimos três anos, porém, em situações semelhantes, o RH é o primeiro setor a ser comunicado. Nas decisões estratégicas, por exemplo, como compra de outra empresa, o RH não participa, porque é uma responsabilidade da área comercial e a diretoria.

A reforma trabalhista tornou as negociações com os sindicatos mais complexas e, no último ano, perduraram por mais tempo porque houve divergências entre as partes, por exemplo, sobre o contrato intermitente, os sindicatos propuseram de uma forma e a empresa de outra. "O doze por trinta e seis, com a nova legislação você não precisa pagar feriados trabalhados, os sindicatos insistem em manter os pagamentos de feriado, e foi difícil tirar em alguns sindicatos e em muitos ainda não tiramos" (Ent.Delta). O número de trabalhadores associados aos sindicatos de trabalhadores não se alterou após a reforma trabalhista. 
Tabela 18 Síntese das respostas das entrevistas com gestores de RH sobre gestão de RH e relações de trabalho.

\begin{tabular}{|c|c|c|c|c|}
\hline Questões & Empresa Alpha & Empresa Beta & Empresa Gamma & Empresa Delta \\
\hline $\begin{array}{l}\text { Participação do RH no } \\
\text { comitê executivo. }\end{array}$ & $\begin{array}{l}\text { Sim, o vice } \\
\text { presidente de RH. }\end{array}$ & Não ocorre. & Sim. & Sim. \\
\hline $\begin{array}{l}\text { Influência dos } \\
\text { sindicatos dos } \\
\text { trabalhadores na } \\
\text { organização. }\end{array}$ & $\begin{array}{l}\text { Boa relação, ação } \\
\text { direta nas } \\
\text { negociações de PLR } \\
\text { e banco de horas. }\end{array}$ & $\begin{array}{l}\text { Interação nas relações } \\
\text { de trabalho e acordos } \\
\text { coletivos. }\end{array}$ & $\begin{array}{l}\text { Intervenção de } \\
\text { sindicatos do cliente, } \\
\text { como o sindicato dos } \\
\text { metalúrgicos. } \\
\text { Negociação de PLR } \\
\text { e banco de horas. }\end{array}$ & $\begin{array}{l}\text { Acordos coletivos } \\
\text { e convenção } \\
\text { coletiva. }\end{array}$ \\
\hline $\begin{array}{l}\text { Existência de um } \\
\text { profissional de RH nas } \\
\text { negociações coletivas. }\end{array}$ & $\begin{array}{l}\text { Sim, coordenador de } \\
\text { relações sindicais. }\end{array}$ & $\begin{array}{l}\text { Sim, coordenadora de } \\
\text { relações de trabalho. }\end{array}$ & $\begin{array}{l}\text { Sim, ex-gerente de } \\
\text { RH, atual consultor } \\
\text { de relações de } \\
\text { trabalho. }\end{array}$ & $\begin{array}{l}\text { Sim, o gerente de } \\
\text { RH. }\end{array}$ \\
\hline $\begin{array}{l}\text { Participação dos } \\
\text { sindicatos dos } \\
\text { trabalhadores no } \\
\text { comitê executivo da } \\
\text { organização. }\end{array}$ & $\begin{array}{l}\text { Não, porque os } \\
\text { sindicatos dos } \\
\text { trabalhadores são } \\
\text { descentralizados. }\end{array}$ & $\begin{array}{l}\text { Não, porque os } \\
\text { objetivos das partes } \\
\text { são diferentes. }\end{array}$ & $\begin{array}{l}\text { Não, porque são } \\
\text { interesses distintos. }\end{array}$ & $\begin{array}{l}\text { Não, somente são } \\
\text { envolvidos quando } \\
\text { o assunto envolve } \\
\text { temas da } \\
\text { convenção coletiva } \\
\text { ou desligamentos. }\end{array}$ \\
\hline $\begin{array}{l}\text { Existência de comissão } \\
\text { de trabalhadores. }\end{array}$ & Não existe. & $\begin{array}{l}\text { Não, porque as } \\
\text { unidades estão } \\
\text { geograficamente } \\
\text { distantes. }\end{array}$ & $\begin{array}{l}\text { Não, somente } \\
\text { existem } \\
\text { representantes nas } \\
\text { unidades com maior } \\
\text { número de } \\
\text { funcionários. }\end{array}$ & Não existe. \\
\hline $\begin{array}{l}\text { Existência de canais de } \\
\text { comunicação para os } \\
\text { trabalhadores }\end{array}$ & $\begin{array}{l}\text { Sim, analisado por } \\
\text { um comitê de ética }\end{array}$ & $\begin{array}{l}\text { Sim, através de uma } \\
\text { ferramenta chamada } \\
\text { Speak up, telefone ou } \\
\text { e-mail. }\end{array}$ & $\begin{array}{l}\text { Sim, através de canal } \\
\text { aberto e tratado por } \\
\text { um comitê. }\end{array}$ & $\begin{array}{l}\text { Sim, telefone, e- } \\
\text { mail e contato } \\
\text { direto. }\end{array}$ \\
\hline $\begin{array}{l}\text { Participação do RH em } \\
\text { mudanças estratégicas. }\end{array}$ & Sim. & Não ocorre. & Não ocorre. & Não ocorre. \\
\hline $\begin{array}{l}\text { Impactos da reforma } \\
\text { trabalhista. }\end{array}$ & $\begin{array}{l}\text { Desempenho mais } \\
\text { ativo dos sindicatos } \\
\text { dos trabalhadores. }\end{array}$ & $\begin{array}{l}\text { Flexibilização do } \\
\text { horário de intervalos e } \\
\text { homologações } \\
\text { realizadas nas } \\
\text { empresas. }\end{array}$ & $\begin{array}{l}\text { Redução do } \\
\text { intervalo } \\
\text { intrajornada. }\end{array}$ & $\begin{array}{l}\text { Negociações mais } \\
\text { complexas. }\end{array}$ \\
\hline
\end{tabular}

Fonte: Elaboração da autora.

Três empresas declaram que um responsável de RH participa do comitê executivo, porém, duas delas reconhecem que em questões estratégicas o RH não é envolvido, mas participam da implementação e viabilização da estratégia relacionada às questões das pessoas. Os sindicatos influenciam as organizações, principalmente para os acordos coletivos (PLR, banco de horas e etc.) e possuem boa interação com as empresas. As negociações são realizadas pelos especialistas em relações de trabalho de cada empresa e os sindicatos dos trabalhadores. 
Não há participação dos sindicatos no comitê executivo das empresas, segundo os entrevistados das empresas, porque seria difícil obter um representante de todos os sindicatos para que um participasse, também observam haver objetivos diferentes entre sindicato e empresa, para um o foco é o trabalhador e o outro o capital, e não há interesse da organização nesta participação. Também nenhuma das empresas possuem comissão de trabalhadores, contudo, existem representantes dos trabalhadores de cada unidade incentivados pelos sindicatos para participação nas assembleias ou para representar o grupo diante da empresa. No entanto, todas as empresas apresentaram canais de comunicação com os trabalhadores, de modo que os empregados podem apresentar suas ideias e reclamações sempre que necessário.

A percepção dos entrevistados das empresas a respeito da reforma trabalhista foi que trouxe maior complexidade nas negociações com os sindicatos, porém, agregou ganhos para as empresas como flexibilização de horas de almoço e diferentes formas de contrato de carga horária, conforme observado nas cláusulas da convenção coletiva 2018/2019 apresentada na tabela 15. As mudanças na legislação trabalhista motivaram os sindicatos a estarem mais próximos aos funcionários e mais ativos em seus propósitos. O número de associados aos sindicatos não sofreu alterações.

\subsubsection{Os sindicatos do setor}

O sindicato representado pelo sindicalista 1 (Sind.01) possui 14.000 associados, a proporção etária da força de trabalho é de $5 \%$ de 18 a 24 anos, $80 \%$ de 25 a 49 anos e $15 \%$ de 50 anos ou mais. Dados semelhantes são verificados na RAIS (2018) e nos dados apresentados pelas empresas estudadas, nas quais o maior número de trabalhadores está inserido na faixa etária de 25 a 49 anos. A proporção da maior parte da força de trabalho associada ao sindicato é de $80 \%$ de trabalhadores operacionais, semelhante resultado observa-se nos dados obtidos pelas empresas pesquisadas, sendo $85 \%$ de trabalhadores operacionais. Para Sind.01, o mercado de refeições coletivas está crescendo.

O sindicato representado pelo sindicalista 2 (Sind.02) possui uma base de 18.000 empregados, sendo 15.000 associados ao sindicato, representando $83 \%$ de empregados sindicalizados. A proporção etária da força de trabalho que está associada é de $15 \%$ de 18 a 24 anos, $70 \%$ de 25 a 49 anos e $15 \%$ de 50 anos ou mais, novamente dados semelhantes aos obtidos pela RAIS e empresas pesquisadas. A proporção da força de trabalho é de $5 \%$ gerentes, $15 \%$ profissionais sem responsabilidade gerencial e $80 \%$ de operacionais, também 
semelhante aos dados das empresas estudadas. Para Sind.02, o mercado de refeições coletivas apresenta-se sem mudanças.

O sindicato representado pelo sindicalista 3 (Sind.03) possui uma base de 12.000 empregados, sendo 7.000 associados ao sindicato, representando $58 \%$ de empregados sindicalizados. A proporção etária da força de trabalho é de $50 \%$ entre 18 e 24 anos e $50 \%$ de 25 a 49 anos, estes valores são diferentes aos dados da RAIS, que apresentam 9,2\% entre 18 e 24 anos e $71 \%$ para 25 e 49 anos, e com relação às empresas pesquisadas também encontramos diferença para as faixas etárias de 18 a 24 anos, que apresentam uma média de 16,6\%, porém, para as faixas etárias de 24 a 49 anos o valor está mais próximo, sendo a média para esta faixa etária declarada pelas empresas de $61 \%$. A proporção da força de trabalho é de $90 \%$ operacionais, valor similar ao apresentado pelas empresas de $85 \%$ trabalhadores operacionais, $5 \%$ gerentes e $5 \%$ profissionais sem responsabilidade gerencial. Para Sind.03, o mercado de refeições coletivas está diminuindo.

Tabela 19 Síntese dos dados das entrevistas com sindicalistas do setor de refeições coletivas do estado de São Paulo.

\begin{tabular}{|c|c|c|c|c|}
\hline \multicolumn{2}{|c|}{ Característica } & Sindicato 1 & Sindicato 2 & Sindicato 3 \\
\hline \multicolumn{2}{|l|}{$\mathrm{N}^{\mathrm{o}}$ trabalhadores da base } & Não respondeu & 18.000 & 12.000 \\
\hline \multicolumn{2}{|l|}{$\mathrm{N}^{\circ}$ de associados } & 14.000 & 15.000 & 7.000 \\
\hline \multicolumn{2}{|l|}{ Taxa de sindicalização } & Não respondeu & $83 \%$ & $58 \%$ \\
\hline \multirow{3}{*}{$\begin{array}{l}\text { Proporção etária da força } \\
\text { de trabalho }\end{array}$} & 18 a 24 anos & $5 \%$ & $15 \%$ & $50 \%$ \\
\hline & 25 a 49 anos & $80 \%$ & $70 \%$ & $50 \%$ \\
\hline & $\begin{array}{l}50 \text { anos ou } \\
\text { mais }\end{array}$ & $15 \%$ & $15 \%$ & $0 \%$ \\
\hline $\begin{array}{l}\text { Proporção de } \\
\text { trabalhadores } \\
\text { operacionais } \\
\end{array}$ & & $80 \%$ & $80 \%$ & $90 \%$ \\
\hline Situação do mercado & & Crescendo & Sem mudanças & Diminuindo \\
\hline $\begin{array}{l}\text { Influência dos sindicatos } \\
\text { dos trabalhadores na } \\
\text { organização. }\end{array}$ & & $\begin{array}{l}\text { Na definição da PLR, } \\
\text { podendo ocorrer } \\
\text { paralizações se } \\
\text { necessário. }\end{array}$ & $\begin{array}{l}\text { Na negociação de PLR, } \\
\text { banco de horas e } \\
\text { eventuais problemas } \\
\text { com os trabalhadores. }\end{array}$ & $\begin{array}{l}\text { Regulamentar os } \\
\text { direitos dos } \\
\text { trabalhadores. }\end{array}$ \\
\hline $\begin{array}{l}\text { Participação dos } \\
\text { sindicatos dos } \\
\text { trabalhadores no comitê } \\
\text { executivo da organização. }\end{array}$ & & Não. & Não. & Não. \\
\hline $\begin{array}{l}\text { Existência de comissão } \\
\text { de trabalhadores. }\end{array}$ & & $\begin{array}{l}\text { Sim, são criadas pelos } \\
\text { sindicatos dos } \\
\text { trabalhadores para } \\
\text { representação nas } \\
\text { assembleias. }\end{array}$ & $\begin{array}{l}\text { Não, porque os } \\
\text { trabalhadores não estão } \\
\text { todos fisicamente em } \\
\text { um único local. }\end{array}$ & $\begin{array}{l}\text { Sim, somente em } \\
\text { unidades com } \\
\text { maior número de } \\
\text { funcionários ou } \\
\text { que tenham algum } \\
\text { tipo de problema. }\end{array}$ \\
\hline
\end{tabular}




\begin{tabular}{|c|c|c|c|}
\hline $\begin{array}{l}\text { Existência de canais de } \\
\text { comunicação para os } \\
\text { trabalhadores }\end{array}$ & $\begin{array}{l}\text { Sim, Whatsapp, } \\
\text { facebook, } \\
\text { pessoalmente e nas } \\
\text { assembleias. }\end{array}$ & $\begin{array}{l}\text { Sim, Whatsapp, } \\
\text { telefone, e-mail, } \\
\text { facebook e } \\
\text { pessoalmente. }\end{array}$ & $\begin{array}{l}\text { Sim, visitas à } \\
\text { empresa, site e } \\
\text { Whatsapp. }\end{array}$ \\
\hline $\begin{array}{l}\text { Participação dos } \\
\text { sindicatos em mudanças } \\
\text { estratégicas. }\end{array}$ & Não existe. & Não existe. & Não existe. \\
\hline $\begin{array}{l}\text { Impactos da reforma } \\
\text { trabalhista. }\end{array}$ & $\begin{array}{l}\text { Acordo para manter } \\
\text { as homologações no } \\
\text { sindicato dos } \\
\text { trabalhadores e novas } \\
\text { formas de contrato. }\end{array}$ & $\begin{array}{l}\text { Diminuição dos } \\
\text { direitos dos } \\
\text { trabalhadores e não } \\
\text { obrigatoriedade da } \\
\text { contribuição sindical }\end{array}$ & $\begin{array}{l}\text { Acordo com o } \\
\text { sindicato patronal } \\
\text { para não haver } \\
\text { acordo individual } \\
\text { de contrato e } \\
\text { regulamentação de } \\
\text { novas formas de } \\
\text { carga horária. }\end{array}$ \\
\hline
\end{tabular}

Fonte: Elaboração da autora.

A taxa de sindicalização apresentada pelos sindicatos dos trabalhadores foi em média $70 \%$, valor superior à média declarada pelas empresas que foi de $26 \%$, embora uma das empresas tenha mencionado como proporção de empregados sindicalizados o valor de $50 \%$. O número maior de empregados possui faixa etária entre 25 a 49 anos, semelhante resultado encontra-se nos dados da RAIS, tabela 11, e nos dados obtidos pelas empresas, tabela 16. A proporção de trabalhadores operacionais apresenta-se em média de $83 \%$, dados similares foram obtidos pelas empresas, média de $85 \%$, apresentado na tabela 16 . A percepção da situação do mercado para os sindicalistas foi divergente para os três entrevistados, igualmente ocorrido nas respostas das empresas.

Nenhum dos sindicatos participa do comitê executivo das empresas. Os motivos relatados por eles são que os sindicatos se limitam às negociações coletivas e que não há interesse das empresas nesta participação. As empresas desconfiam dos sindicatos, apesar de terem um bom relacionamento. Quando há um número grande de demissões, o sindicato é somente comunicado. Ainda assim, o mesmo se interessa na possibilidade de participar do comitê executivo. "As empresas geralmente não gostam de sindicalista, então, as portas não estão abertas para nós" (Sind.02). Todos os sindicatos possuem canais de comunicação com os trabalhadores, de forma a manter este contato constantemente.

Os sindicatos influenciam as organizações de forma a padronizar os benefícios do trabalhador. "O sindicato estabelece limites, parâmetros, para que não seja viável a abertura de um estabelecimento sem esses critérios" (Sind.01). As negociações de PLR, banco de horas e etc. ocorrem entre empresa e sindicato, porém existem alguns acordos realizados pela federação aos sindicatos que se interessam em unir-se e fazer um acordo único. 
Os sindicatos dos trabalhadores possuem contato com o RH das empresas constantemente. Esse contato ocorre quando há alguma reclamação dos trabalhadores e principalmente no período das negociações coletivas. Neste setor existe muito diálogo entre os sindicatos e as empresas e as formas de contato são via telefone, e-mail ou pessoalmente. As negociações ocorrem com o responsável de RH ou um especialista em relações de trabalho, e em empresas menores pode ocorrer até com um auxiliar administrativo. Se a negociação não atinge os objetivos do sindicato, podem ocorrer paralisações ou acesso a instâncias jurídicas. Houve greve em 2016 em São Paulo, no subsetor de merenda escolar, e foi obtido êxito. Através de paralizações, no ABC conseguiu-se um valor de PLR maior em unidades localizadas nas montadoras.

Quanto à existência de comissão de trabalhadores as respostas foram diferentes para os três sindicatos. Um deles disse incentivar esta prática quando uma unidade possui muitos problemas. Outro sindicato diz que em uma unidade grande com muitos trabalhadores procura-se sempre criar representantes para participarem das negociações coletivas. E o outro sindicato desconhece esta prática nas unidades com as quais tem contato, pois são unidades fisicamente distantes. Portanto, podem existir representantes dos trabalhadores em unidades com número de funcionários maior, porém, não existem comissões de trabalhadores nestas empresas, pois as unidades estão em diferentes locais, dificultando este tipo de organização.

Os trabalhadores possuem diversos canais de comunicação com o sindicato como email, site, telefone e o mais utilizado canal é o de mensagens eletrônicas (WhatsApp). Pessoalmente também o trabalhador pode colocar suas ideias e reclamações e em assembleias promovidas pelo sindicato.

Não houve mudanças nas empresas nos últimos três anos, porém quando houve uma fusão de duas empresas de refeições coletivas em um período anterior a este, os sindicatos foram apenas comunicados após a decisão. Em alguns casos, eles descobrem através de boatos e então contatam a empresa para entender melhor as situações.

A reforma trabalhista, na percepção dos sindicalistas, resultou em mais vantagens para as empresas e reduziu os benefícios dos trabalhadores. "Ela foi feita unilateralmente, porque só ouviram quem estava legislando sob o lobby de interessadas, do lado patronal" (Sind.01). Portanto, o impacto gerado pela reforma trabalhista sobre os sindicatos dos trabalhadores foi o aumento da complexidade das negociações com o sindicato patronal para manter alguns procedimentos como eram realizados anteriormente, como as homologações, conforme observado na cláusula da Convenção Coletiva 2018/2019 apresentada na tabela 
15, "As rescisões de contrato de trabalho, com tempo de serviço igual ou superior a 12 meses, deverão ser preferencialmente homologadas no sindicato." (CCT, 2019). Para os sindicatos menores e menos estruturados o impacto financeiro foi maior após a retirada da contribuição sindical, porém os sindicatos maiores buscaram por mais associações, e aumentaram, assim, os números de associados, conseguindo se manter financeiramente.

\subsection{Discussão dos resultados}

Os resultados obtidos com esta pesquisa demonstraram que as empresas de refeições coletivas apresentam características de gestão estratégica de $\mathrm{RH}$, conforme definições operacionais apresentadas na tabela 2. O registro documental das estratégias de RH é declarado em três das empresas pesquisadas. Demonstra-se assim um atributo de GERH conforme Hope-Hailey et al (1997) que define a existência de registro documental das estratégias de RH um aspecto da GERH. Observa-se também que os gestores de RH das quatro empresas estão envolvidos nas decisões políticas de RH, conforme tabela 14, e são envolvidos na implementação e viabilização da estratégia de negócio estabelecida. Duas empresas declaram que um responsável de RH participa do comitê executivo. As demais reconhecem que em questões estratégicas o RH não é envolvido. Esta observação pode demonstrar que o RH destas empresas pode não apresentar-se completamente estratégico, conforme Purcelll (1995), Brewster et al. (1997) e Seehan (2005), que definem uma GERH possuir a presença do gestor de $\mathrm{RH}$ no comitê executivo e envolvido nas decisões estratégicas. Porém, esta é uma característica de RH de empresas que possuem uma única linha de negócio, nas quais o RH participa de decisões relacionadas somente aos funcionários (Ulrich et al, 2008), ou seja, para este tipo de negócio, como as empresas estudadas do setor de refeições coletivas, a participação de um responsável de RH no comitê executivo pode não se fazer imprescindível. Contudo, o registro de uma estratégia de RH e participação nas decisões políticas da área demonstram a gestão estratégica de RH na amplitude em que ela é necessária para este tipo de negócio e organização.

O número de vínculos do mercado de refeições coletivas no Brasil diminuiu 7\% de 2015 a 2017, mas no estado de São Paulo aumentou em 0,5\% neste mesmo período, no entanto a cidade de Sorocaba, por exemplo, diminuiu em 1,9\% o número de trabalhadores (RAIS, 2018). Observa-se então que há uma desigualdade no comportamento do mercado conforme a região. Constata-se uma diferença na percepção do mercado pelas empresas, pois dois gestores declararam que o mercado está crescendo e dois que está diminuindo. Verifica- 
se que a percepção de diminuição está relacionada ao comportamento da própria empresa em que o entrevistado atua e não do mercado como um todo, conforme as declarações, “. . . um dos motivos é o encerramento mesmo dos postos de trabalho e também o início da utilização de ferramentas de trabalho remotas." (Ent.Beta), e "Está diminuindo, porque muitos órgãos públicos estão internalizando a confecção das refeições” (Ent.Delta).

O setor de refeições coletivas apresenta-se com uma mão de obra de maioria feminina, de meia-idade e baixa escolaridade. A mão de obra é de 77\% trabalhadores do sexo feminino e $23 \%$ do sexo masculino, representado na figura 9. A faixa etária predominante dos trabalhadores do setor está entre 25 a 49 anos, $71 \%$. Dados que também foram encontrados nas entrevistas com as empresas e sindicalistas. A escolaridade destes trabalhadores é predominantemente baixa, sendo $86,3 \%$ dos trabalhadores com a escolaridade até o ensino médio. Observamos que a escolaridade dos entrevistados é diferente, conforme apresentado na tabela 5 , pois os gestores de RH possuem nível superior e dois deles realizaram pós-graduação em RH e relações sindicais, em contrapartida, somente um sindicalista possui nível superior, os demais possuem como escolaridade o ensino médio. Esta diferença de escolaridade pode causar impacto nos resultados das negociações coletivas, uma vez que são estes os atores desta conversação.

Cerca de $85 \%$ da força de trabalho está em atuação operacional, conforme entrevistas das empresas e sindicalistas e a faixa de remuneração média está entre R\$1000,00 e R\$ 1500,00 (RAIS, 2018), conforme demonstrado na figura 11. De acordo com CCT (2019), o salário normativo da categoria é de $\mathrm{R} \$ 1.246,96$. Verifica-se então que a maioria dos vínculos empregatícios são de nível operacional e os valores das remunerações praticadas são as negociadas pela convenção coletiva. Constata-se então a influência dos sindicatos na remuneração de grande parte dos trabalhadores do setor, através da sua atuação na convenção coletiva.

A média das taxas de sindicalização apresentada pelas empresas foi de $26 \%$, sendo que a Empresa Alpha declarou 50\%. A média das taxas de sindicalização informada pelos sindicalistas foi de $70 \%$. Apesar da diferença dos valores obtidos, observa-se uma taxa de sindicalização de média para alta, em comparação à média nacional em 2017 que foi de 14,4\% (PNAD, 2018). Demonstra-se assim uma característica das relações de trabalho nas empresas estudadas, conforme Crouch (1993). Em suma, o setor de refeições coletivas revela-se como um setor de maioria feminina, de força de trabalho operacional e de média para alta sindicalização. 
Os sindicatos influenciam as organizações, principalmente para os acordos coletivos (PLR, banco de horas e etc.) e possuem boa interação com as empresas. Os sindicalistas confirmaram esta afirmação de influência e relatam padronizar os benefícios do trabalhador através das negociações coletivas. Existe contato constante dos sindicatos com o RH das empresas. Os contatos ocorrem via telefone, aplicativos de mensagens eletrônicas Whatsapp, e-mail e pessoalmente que podem ocorrer uma vez por ano, por causa dos acordos coletivos, e a qualquer momento em que seja necessário.

As negociações são realizadas pelos especialistas em relações de trabalho de cada empresa e os sindicatos. As UANs localizadas em empresas metalúrgicas sofrem influência do sindicato deste setor, resultando em negociações e conquistas diferentes das outras unidades localizadas em empresas de outros setores. Esta influência dos sindicatos dos metalúrgicos do $\mathrm{ABC}$ sob outras categorias já se observa desde 1978, quando houve a paralização de uma indústria automobilística em São Bernardo do Campo, que resultou em um marco das negociações coletivas, motivando diversas categorias de trabalhadores a realizarem greves devido às reivindicações salariais (Amorim, 2015). Quando a negociação não atinge os objetivos dos sindicatos, podem ocorrer greves como em 2016 em São Paulo, no subsetor de merenda escolar e foi também através de paralizações que no $\mathrm{ABC}$ conseguiuse um valor de PLR maior, conforme relatado pelos sindicalistas.

A duração dos vínculos no setor apresenta-se de forma curta, abaixo de 2 anos. Conforme tabela 13, a faixa de tempo de trabalho mais frequente é a de 6 a 23,9 meses, $34,6 \%$ dos vínculos e $21,9 \%$ dos trabalhadores possuem seu período de trabalho de até 6 meses. Gould e Desjardins (2012) sugerem que a relação de emprego é mais afetada pelo conflito do que pela cooperação quando a relação entre empregado e empregador é de curta duração. Observamos uma relação de cooperação através dos relatos de canais de comunicação entre empregados e empregadores, e poucos incidentes de paralisações. Constata-se uma interação constante entre sindicato e empresa, o que pode minimizar a presença de conflitos, mesmo que a relação entre empresa e funcionário seja de curto prazo. Gould e Desjardins (2012) também discutem que definições de longo e curto prazo variam conforme o tipo de emprego.

A participação dos sindicatos no comitê executivo das empresas não ocorre porque, segundo as empresas, seria difícil determinar um único representante de todos os sindicatos, os interesses das partes são diferentes, do lado da empresa seria o negócio e dos sindicatos, os trabalhadores, e não há interesse por parte das organizações para que essa participação aconteça. Os sindicalistas declararam também a não participação no comitê executivo das 
empresas, pois se limitam às negociações coletivas e não há interesse das duas partes nesta participação. O não envolvimento dos sindicatos em situações de decisões estratégicas de RH, é um fato já observado na pesquisa de Cruz et al. (2012), que demonstra que a discussão de gestão de competências, por exemplo, era um assunto ausente nas negociações e desconhecida pelos sindicatos. Constata-se do mesmo modo que a legislação brasileira determina que as convenções e acordos coletivos contemplam todos os trabalhadores e, acordos em conselhos administrativos ocorrem raramente (Amorim, Fischer \& Trullen, 2016).

Nenhuma das empresas possui comissão de trabalhadores, porém, existem representantes dos trabalhadores de cada unidade incentivados pelos sindicatos para participação nas assembleias ou para representar o grupo diante da empresa. Outro motivo apresentado foi o não interesse dos trabalhadores em obter esta responsabilidade, "Ninguém quer essa responsabilidade porque todo mundo reclamará de tudo e a pessoa pode se perder no dia a dia" (Ent.Beta). As unidades são dispersas pelo estado então se torna difícil este tipo de mobilização, e semelhante motivo foi apontado pelos sindicalistas que afirmaram que as unidades são fisicamente distantes. Através destas informações pode-se demonstrar como os sindicatos atuam no setor de refeições coletivas, conforme Sisson (1993).

A convenção coletiva é realizada no mês de junho e os acordos coletivos são individualizados entre as empresas e o sindicato de trabalhadores de cada região. A duração das negociações pode ser de um a quatro meses. Todos os RHs das organizações estudadas possuem um especialista em relações de trabalho e somente em uma empresa o especialista é um consultor, porém ex-gerente de RH da empresa. Todas as empresas pesquisadas possuem canais de comunicação entre trabalhadores e empresa, que oferecem liberdade de expor sugestões e reclamações, que são sigilosos e cujo conteúdo é analisado pelo RH nacional e até internacional. Os meios utilizados são e-mail e telefone. Na empresa Delta, que é familiar, este canal é aberto diretamente a qualquer gestor, bem como aos proprietários da empresa. Observamos que o setor possui relações de trabalho formais, através dos sindicatos, e informais, através dos diversos canais de comunicação. Uma vez que esta relação pode influenciar em decisões a respeito da organização, o resultado para o desempenho da empresa é positivo e pode complementar o impacto benéfico dos dois tipos de relações (Litwin \& Eaton, 2018).

A percepção dos entrevistados das empresas a respeito da reforma trabalhista foi que ela trouxe maior complexidade nas negociações com os sindicatos, porém agregou ganhos para as empresas como flexibilização de horas de almoço e diferentes formas de contrato de carga horária, conforme observamos na análise do documento da Convenção Coletiva 2018/2019, 
"Considera-se trabalho em regime de tempo parcial aquele cuja duração não exceda 30 horas semanais, sem possibilidades de horas suplementares, ou aquela cuja duração não exceda a 26 horas semanais, com a possibilidade de acréscimo de até 6 horas suplementares e o salário a ser pago será proporcional à sua jornada, em relação aos empregados que cumprem tempo integral...” (CCT, 2019)

e

"O contrato de trabalho intermitente é considerado quando há alternância de períodos de prestação de serviços e de inatividade, determinados em horas, dias ou meses, somente para atividades eventuais. Este tipo de contrato somente poderá ser celebrado para novas contratações e a remuneração não poderá ser inferior ao salário pago para os demais empregados que exerçam a mesma função e terão direito a vale transporte e vale refeição e/ou refeição no local de trabalho" (CCT, 2019).

As mudanças motivaram os sindicatos a estarem mais próximos aos funcionários e mais ativos em seus propósitos. O número de associados aos sindicatos não sofreu alterações. No entanto, para os sindicalistas houve necessidade de negociações para manter alguns procedimentos como as homologações, observou-se esta cláusula no documento da Convenção Coletiva 2018/2019, “As rescisões de contrato de trabalho, com tempo de serviço igual ou superior a 12 meses, deverão ser preferencialmente homologadas no sindicato" (CCT, 2019), e confirmam que buscaram mais associações para manter-se financeiramente após a permissão de não obrigatoriedade da contribuição sindical estabelecida pela reforma trabalhista.

Encontramos nesta pesquisa características da gestão estratégica de $\mathrm{RH}$ nas organizações estudadas e aspectos positivos das relações de trabalho tal como sindicatos de trabalhadores participativos, influentes e ativos no exercício das empresas, interação constante e canais de comunicação estabelecidos e acessíveis entre empregados, empresa e sindicatos dos trabalhadores e, por parte das empresas a presença de um responsável qualificado em relações de trabalho. Os sindicatos dos trabalhadores, ao apresentarem-se de forma influente, atuante e presente, podem estimular o desenvolvimento de aspectos de gestão estratégica de RH para que a organização consiga atingir seus objetivos. Sendo assim, observamos que as relações de trabalho do setor de refeições coletivas, descrita nesta pesquisa, podem contribuir para a gestão estratégica de RH destas empresas, semelhante como verificou-se na pesquisa de Vernon e Brewster (2013,) que concluiu que o sindicalismo facilita a integração estratégica das funções de RH. 


\section{CONSIDERAÇÕES FINAIS}

Esta dissertação abordou a gestão estratégica de RH e as relações de trabalho do setor de refeições coletivas. Sua base teórica foi desenvolvida a partir dos conceitos de gestão estratégica de RH e relações de trabalho, assim como artigos recentes que discutem sobre estas duas teorias. Das bases teóricas apresentadas no capítulo 2, foram destacadas as ferramentas teóricas necessárias para os estudos e análises realizados nos capítulos 3 e 4 .

De acordo com o primeiro objetivo específico desta pesquisa, investigar o quanto as empresas de refeições coletivas adotam políticas e práticas de gestão estratégica de RH, ao final deste estudo encontramos os seguintes achados: as empresas de refeições coletivas pesquisadas por este estudo, apresentam características de GERH como registro das estratégias de $\mathrm{RH}$, participação de um responsável de $\mathrm{RH}$ no comitê executivo e envolvimento de gestores de RH nas decisões políticas de RH (Purcell, 1995; Brewster et al, 1997; Sheehan, 2005).

Conforme o segundo objetivo específico, que era de identificar e analisar características específicas de relações de trabalho, observou-se que o setor de refeições coletivas apresenta-se com uma mão de obra de maioria feminina, baixa escolaridade e de maior parte operacional. A taxa de sindicalização é de média para alta, demonstrando a influência dos sindicatos dos trabalhadores no setor. A influência principal dos sindicatos dos trabalhadores aparece nos acordos coletivos, como PLR e banco de horas. Existe boa interação entre os sindicatos dos trabalhadores e as empresas que possuem especialistas em relações de trabalho. Esta alta taxa de sindicalização, assim como a comunicação constante e interação entre sindicatos e organizações, contribuem para a aplicação e desenvolvimento da gestão estratégica de RH dentro destas empresas. Sendo assim, atendemos ao terceiro objetivo proposto de relacionar as características das relações de trabalho com a adoção de práticas estratégicas de RH por estas organizações.

Ao atingir os três objetivos específicos propostos, esta dissertação também alcançou seu objetivo principal: identificar e analisar a gestão estratégica de pessoas nas empresas de restaurantes de refeições coletivas no estado de São Paulo, tendo como foco as relações de trabalho.

Além disso, destacamos a discussão do assunto sobre a reforma trabalhista, citada pelos entrevistados da pesquisa. A reforma trabalhista resultou em benefícios para as empresas como flexibilização dos intervalos de jornada e diferentes formas de contrato. A percepção dos sindicalistas foi que decorreram mais vantagens para as empresas e retirada 
de benefícios dos trabalhadores, portanto, isto promoveu um aumento da complexidade das negociações coletivas, com o objetivo de minimizar os impactos negativos para os empregados. Contudo, após a aprovação da reforma trabalhista, os sindicatos demonstraram maior ação com relação aos trabalhadores, aumentando assim o número de associados e mantendo-se financeiramente, mesmo após a retirada da obrigatoriedade da contribuição sindical.

A pesquisa realizada foi delimitada aos casos estudados e apresenta limitações, decorrentes das próprias opções metodológicas. A pesquisa de abordagem qualitativa focou na experiência dos gestores de RH e de sindicalistas. Alguns elementos, neste caso, podem representar limitações, uma vez que as conclusões do estudo dependeram da percepção e memória dos entrevistados. Outro aspecto observado foram os dados disponibilizados pela base de dados da RAIS somente referente ao ano de 2017, pois não estavam disponíveis para consulta as informações do ano de 2018 , até a conclusão da coleta de dados desta pesquisa.

Alguns assuntos podem se revelar para futuras pesquisas como, estudar o comportamento do RH e das relações de trabalho no setor de refeições coletivas em outros estados do Brasil. Observando se os resultados são semelhantes ou diferentes dos encontrados por esta pesquisa no estado de São Paulo. Outra sugestão seria obter a percepção dos gestores de linha a respeito do tema pesquisado, e também constatar como a gestão estratégica de RH e as relações de trabalho se apresentam em sua aplicação na operação das unidades de alimentação e nutrição.

Esta pesquisa pode contribuir para o conhecimento prático para a gestão de $\mathrm{RH}$ e as relações de trabalho do setor de refeições coletivas. Trabalhou-se diretamente com os gestores de RH e sindicalistas para melhor compreensão das práticas utilizadas, podendo ajudar na definição das estratégias de negócio e RH (Cascio, 2015). 


\section{REFERÊNCIAS BIBLIOGRÁFICAS ${ }^{5}$}

ABERC. (2018). Associação Brasileira de Empresas de Refeições Coletivas. Recuperado em 8 de março de 2019, de www.aberc.com.br.

Abreu, E. S., \& Spinelli, M. G. N. (2013). A unidade de alimentação e nutrição. In Gestão de unidades de aliemntação e nutrição: um modo de fazer (pp. 35-42). São Paulo: Metha.

Albuquerque, L. G. (2002). A Gestão Estratégica de Pessoas. In M. T. Fleury (Ed.), As pessoas na organização. São Paulo: Gente.

Amorim, Wilson Aparecido Costa de. (2017). Gestão de recursos humanos e relações de trabalho no Brasil: uma análise sob a ótica da teoria dos custos de transação em um conjunto de empresas privadas (Tese de livre docência, FEA-USP), 230.

Amorim, Wilson A. C. (2007). A evolução das organizções de apoio às entidades sindicais brasileiras: um estudo sob a lente da aprendizagem organizacional. Faculdade de Economia e Admnistração da Universidade de São Paulo.

Amorim, Wilson Aparecido Costa. (2015). Negociações coletivas no Brasil: 50 anos de aprendizado. São Paulo: Atlas.

Anthony, W. P., Perrewé, P. L., \& Kacmar, M. K. (1996). Strategic Human Resource. Florida: Hancourt Brace Publishers \& Co.

Araujo, L. C. G., \& Garcia, A. A. (2009). No. São Paulo: Atlas.

Arthur, J. B. (1992). The Link between Business Strategy and Industrial Relations Systems in American Steel Minimills. Industrial and Labor Relations Review, 45(3), 488. https://doi.org/10.2307/2524274

Boxall, P. (1998). Achieving competitive advantage through human resource strategy: Towards a theory of industry dynamics. Human Resource Management Review, 8(3), 264-288.

Boxall, Peter, \& Purcell, J. (2011). Strategy and the process of strategic management. In Strategic Human Resource Management (pp. 39-96).

Brewster, C., Brookes, M., \& Ommeren, J. van. (2006). What determines the size of the HR function? A cross-National Analysis. Human Resource Management, 45(1), 3-21.

\footnotetext{
${ }^{5}$ De acordo com o estilo APA (American Psychological Association 6th edition).
} 
Brewster, C., Larsen, H. H., \& Mayhofer, W. (1997). Integration and Asigment: A Paradox in HRM. Journal of International Management, 3(1), 1-23.

Cascio, W. F. (2015). Strategic HRM: too important for an insular approach. Human Resource Management, 54, 423-426.

CCT. (2019). Convenção Coletiva de Trabalho 2018/2019. São Paulo. Retrieved from http://www.sinterc.org.br/cct/CCT_2018_2019.pdf

Chizzotti, A. (2006). Pesquisa qualitativa em ciências humanas. Petrópolis: Vozes.

CNI. (2017). Modernização trabalhista lei $n^{o}$ 13.467, de 13 de julho de 2017 - panorama anterior e posterior à aprovação -. Brasilia.

Costa, M. da S. (2007). Relações De Trabalho E Regimes De Emprego No Canadá E No Brasil Um Estudo Comparativo. RAE-Eletrônica, 6(2).

CRANET. (2015). Relatório de pesquisa CRANET Brasil:2014. São Paulo.

Creswell, J. W. (2007). Qualitative Inquiry \& Research Design: Choosing among five approaches. Thousand Oaks: Sage Publications, Inc.

Crouch, C. (1993). Industrial Relation and European State Traditions. Oxford: Oxford University Press.

Cruz, M. V. G. da, Sarsur, A. M., \& Amorim, W. A. C. de. (2012). Gestão de competências nas relações de trabalho: o que pensam os sindicalistas? Revista de Administração Contemporânea, 16(5), 705-722. https://doi.org/10.1590/S1415-65552012000500005

Delery, J. E., \& Doty, D. H. (1996). Modes of theorizing in strategic Human Resource Management: tests of universalistic, contingency, and configurational performance predictions. Academy of Management Journal, 39(4), 802-835.

DIEESE. (2017). Reforma trabalhista: riscos e perdas impostos pelo PL 6.787/2016 aos trabalhadores e ao movimento sindical. São Paulo.

Dunlop, J. T. (1993). Industrial relations systems. Boston: HBS Press.

Dutra, J. S., Dutra, T. A., \& Dutra, G. A. (2017). Gestão de pessoas: realidade e desafios futuros. São Paulo: Atlas.

Eisenhardt, K. M. (1989). Building Theories from Case Study Research. Academy of Management Review, 14(4), 532-550.

Fischer, A.L. (2001). O conceito de modelo de gestão de pessoas - Modismo e realidade em gestão de Recursos Humanos nas empresas brasileiras. In Gestão por competências: um modelo avançado para o gerenciamento de pessoas. (pp. 9-21). São Paulo: Gente.

Fischer, A.L. (2002). Um resgate conceitual e histórico dos modelos de gestão de pessoas. In As pessoas na organização (pp. 11-13). São Paulo: Gente. 
Fischer, André Luiz. (2015). Modelo de gestão de pessoas. In P. F. Bendassolli \& J. E. Borges-Andrade (Eds.), Dicionário de psicologia do trabalho e das organizações (pp. 445-452). São Paulo: Casa do psicólogo.

Gil, A. C. (1994). Métodos e técnicas de pesquisa social. São Paulo: Atlas.

Gondim, S. M. ., Souza, J. J., \& Peixoto, A. L. A. (2013). Gestão de pessoas. In L. O. Borges \& L. Mourão (Eds.), O trabalho e as organizações. Porto Alegre: Artmed.

Gould, A. M., \& Desjardins, G. (2012). Static and dynamic views of conflict and cooperation in the employment relationship A new kind of time-based theory with implications for non-standard work forms. https://doi.org/10.1108/PR-07-2012-0109

Hall, S. A. (1997). A centralidade da cultura: notas sobre as revoluções de nosso tempo. Porto Alegre: Educ. Real.

Harpaz, I., \& Meshoulam, I. (2010). The meaning of work , employment relations , and strategic human resources management in Israel. Human Resource Management Review, 20(3), 212-223. https://doi.org/10.1016/j.hrmr.2009.08.009

Hope- Hailey, V., Gratton, L., Stiles, P., \& Truss, C. (1997). A Chameleon Function? HRM in the "90s." Human Resource Management Journal, 7(3), 5-18.

Horn, C. H. (2011). Enfoques sistêmicos sobre relações de trabalho. In E. da UFRGS (Ed.), Relações de trablaho no mundo contemporâneo (pp. 23-40). Porto Alegre.

Huselid, M. A. (1995). the Impact of Human Resource Management Practices on Turnover, Productivity, and Corporate Financial Performance. Academy of Management Journal, 38(3), 635-872. https://doi.org/10.2307/256741

Karen Legge. (2005a). HRM and "strategic" integration with business policy. In Human Resource Management - Rhetorics and Realities (pp. 133-173).

Karen Legge. (2005b). What is Human Resource Management. In Human Resource Management - Rhetorics and Realities (pp. 101-132).

Kaufman, B. E. (2015). Evolution of strategic HRM as seen through two foundings books: 30th anniversary perspective on development of the field. Human Resource Management, 54(3), 389-407.

Lakatos, E. M., \& Marconi, M. de A. (2001). Metodologia do trabalho científico (6a ed.). São Paulo: Atlas.

Lengnick-Hall, M. L., Lengnick-Hall, C. A., Andrade, L. S., \& Drake, B. (2009). Strategic human resource management: The evolution of the field. Human Resource Management Review, 19(2), 64-85. https://doi.org/10.1016/j.hrmr.2009.01.002

Lepak, D. P., \& Snell, S. A. (1999). The Human Resource Arquitecture: Toward a Theory 
of Human Capital Allocation and Development. The Academy of Management Review, 24(1), 31-48.

Lepak, D. P., \& Snell, S. A. (2002). Examining the Human Resource Architecturew: The Relationships Among Human Capital, Employment, and Human Resource Configurations. Journal of Management, 28(4), 517-543. https://doi.org/10.1016/S0149-2063(02)00142-3

Litwin, A. S., \& Eaton, A. E. (2018). Complementary or conflictual? Formal participation, informal participation, and organizational performance. Human Resource Management, 57(1), 307-325. https://doi.org/10.1002/hrm.21835

Macky, K., \& Boxall, P. (2008). High-involvement work processes, work intensification and employee well-being: A study of New Zealand worker experiences. Asia Pacific Journal of Human Resources, 46(1), 38-55.

Maria, I., Jarocki, C., Maria, L., \& Oliveira, B. De. (2014). A arquitetura de recursos humanos nas vinículas no vale do São Francisco. Read, 1(77), 225-253.

Mesomo, I. F. B. (1994). A admnistração de serviços de alimentação (4.ed.). São Paulo.

Miles, M. B., Huberman, A. M., \& Saldaña, J. (2014). Qualitative data analysis: a methods sourcebook. California: Sage Publications, Inc.

Monks, K., Kelly, G., Conway, E., Flood, P., Truss, K., \& Hannon, E. (2012). Understanding how HR systems work: The role of HR philosophy and HR processes. Human Resource Management Journal, 23(4), 379-395. https://doi.org/10.1111/j.17488583.2012.00207.x

Motta, F. C. P., \& Vasconcelos, I. F. . (2002). Teoria geral da administração. São Paulo: Pioneira.

Nogueira, A. J. F. M. (2008). Competências em relações de trabalho. In J. S. Dutra (Ed.). São Paulo: Atlas.

Nogueira, A. M. (2008). Competências em relações de trabalho e sindicais. In J. S. Dutra, M. T. L. Fleury, \& R. Ruas (Eds.), Competências: conceitos, métodos e experiências. São Paulo: Atlas.

Pastore, J., \& Zylberstajn, H. (1988). A administração do conflito trabalhista no Brasil (2a ed). São Paulo: Instituto de pesquisas econômicas.

Pereira, S. M. S. R. (2014). Antropologia da alimentação: cultura e a unidade de alimentação e nutrição. In Gestão de UAN: um resgate do binômio alimentação e nutrição (pp. 0118). São Paulo: Roca.

PNAD, P. N. por amostra de domicilios contínua. (2018). Características adicionais do 
mercado de trabalho 2012-2017.

RAIS. (2019). Relação anual de informações sociais. Retrieved April 10, 2019, from http://bi.mte.gov.br

Richardson, R. J. (1999). Pesquisa social: métodos e técnicas (3 ed rev.). São Paulo: Atlas.

Schmidt, J. A., Pohler, D., \& Willness, C. R. (2018). Strategic HR system differentiation between jobs: The effects on firm performance and employee outcomes. Human Resource Management, 57(1), 65-81. https://doi.org/10.1002/hrm.21836

Sheehan, C. (2005). A Model for HRM Strategic Integration. Personnel Review, 34(2), 192 209.

Sisson, K. (1993). In search of HRM. British Journal of Industrial Relations, 31(2), 201210.

Souza, J. J., \& Peixoto, A. L. A. (2013). Os novos modelos de gestão. In Livia O. Borges \& L. Mourão (Eds.), O trabalho e as organizações (pp. 121-149). Porto Alegre: Artmed.

Teixeira, S., Milet, Z., \& Carvalho, J. (2000). Administração aplicada às unidades de alimentação e nutrição. Belo Horizonte: Atheneu.

Ulrich, D. (2004). Recursos humanos estratégicos: novas perspectivas para os profissionais de RH. São Paulo: Futura.

Ulrich, Dave, Younger, J., \& Brockbank, W. (2008). The twenty first century HR organization. Human Resource Management, 47(4), 829-850.

Ulrich, Dave, Younger, J., Brockbank, W., \& Ulrich, M. (2013). RH de dentro para fora: seis competências para o futuro da área de recursos humanos. Porto Alegre: Bookman.

Vernon, G., \& Brewster, C. (2013). Structural spoilers or structural supports? Unions and the strategic integration of HR functions. The International Journal of Human Resource Management, 24(6), 1113-1129. https://doi.org/10.1080/09585192.2012.703416

Wright, P. M., \& Snell, S. A. (1998). Toward a unifying framework for exploring fit and flexibility in strategic human resource management. Academy of Management Review, 23(4), 756-772.

Wright, Patrick M., \& McMahan, G. C. (1992). Theoretical perspectives for strategic human resource management. Journal of Management, 18(2), 295-320.

Yin, R. K. (2015). Estudo de caso: planejamento e métodos (5 ed.). Porto Alegre: Bookman. 


\section{APÊNDICES}

1. Questionário semi-estruturado para entrevistas em profundidade com gestores de $\mathrm{RH}$ Seção 1: Detalhes Pessoais

\begin{tabular}{|l|l|}
\hline 1.Sexo & \\
\hline 2.Idade & \\
\hline 3.Tempo de casa & \\
\hline 4. Qual é o seu cargo atual? & \\
\hline 5. Qual a sua formação educacional? & \\
\hline
\end{tabular}

6. Conte sua trajetória profissional.

Seção 2: Dados da organização e RH

\begin{tabular}{|c|c|c|c|}
\hline $\begin{array}{l}\text { Quantas pessoas são empregadas por sua } \\
\text { organização no Estado de SP? }\end{array}$ & & & \\
\hline Qual a proporção etária da força de trabalho? & $\begin{array}{l}18 \text { a } 24 \text { anos: } \\
25 \text { a } 49 \text { anos: } \\
50 \text { anos ou mais: }\end{array}$ & & \\
\hline Qual é a proporção da sua força de trabalho? & $\begin{array}{l}\text { a) Gerentes: __ } \% \\
\text { b) Profissionais (sem respo } \\
\text { _ } \% \\
\text { c) Administrativos e/ou ope }\end{array}$ & $\begin{array}{l}\text { abilidade ger } \\
\text { cionais: }\end{array}$ & cial): \\
\hline $\begin{array}{l}\text { Quantas pessoas estão empregadas no } \\
\text { departamento de RH? }\end{array}$ & & & \\
\hline Sua organização tem registrado por escrito: & $\begin{array}{l}\text { Missão: } \\
\text { Estratégia do Negócio : } \\
\text { Estratégia de RH: }\end{array}$ & $\begin{array}{l}\operatorname{Sim}- \\
\operatorname{Sim} \_ \\
\operatorname{Sim}\end{array}$ & $\begin{array}{l}\text { Não } \\
\text { Não } \\
\text { Não }\end{array}$ \\
\hline $\begin{array}{l}\text { Quais são os responsáveis pelas grandes } \\
\text { decisões políticas sobre: }\end{array}$ & treinamento e desenvolv & ento: & \\
\hline
\end{tabular}




\begin{tabular}{|l|l|}
\cline { 2 - 2 } & relações de trabalho: \\
\cline { 2 - 2 } & expansão e redução da força de trabalho: \\
\hline $\begin{array}{l}\text { Qual é a proporção do número de } \\
\text { empregados sindicalizados? }\end{array}$ & \\
\hline $\begin{array}{l}\text { Qual a porcentagem de rotatividade e } \\
\text { absenteísmo pela sua força de trabalho? }\end{array}$ & \\
\hline $\begin{array}{l}\text { Em que país a sede da sua organização está } \\
\text { baseada? }\end{array}$ & \\
\hline $\begin{array}{l}\text { Sua organização é nacional ou } \\
\text { multinacional? }\end{array}$ & Sem Mudanças: \\
\hline $\begin{array}{l}\text { Aonde as políticas de RH são determinadas? } \\
\text { Como você descreve o mercado principal } \\
\text { para os seus serviços? (local, regional, } \\
\text { nacional, continental ou mundial)? }\end{array}$ & \\
\hline $\begin{array}{l}\text { O mercado de refeições coletivas está: } \\
\text { Crescendo: }\end{array}$ \\
\hline
\end{tabular}

Seção 3: Atividade do RH na organização e relações trabalhistas

1. Existe participação de um responsável de RH no comitê executivo ou o equivalente no alto escalão de executivos? Se sim - Como? Se não - Por quê?

2. Os sindicatos influenciam a sua organização? Se sim - Como? Se não - Por quê? (Acordos coletivos, bancos de horas, data base, PLR ou outros?)

3. O RH tem contato com o sindicato dos trabalhadores? Como? Quando? Por quê? Com quem?

4. O RH tem especialista em Relações do Trabalho?

5. Como ocorrem as negociações com os sindicatos? Contrata preposto?

6. Existe a participação dos sindicatos no comitê executivo e nas decisões da empresa? Se sim - Como? Se não - Por quê?

7. A sua organização possui comitê consultivo ou comissão de trabalhadores? Se sim Como? Se não - Por quê?

8. Como os empregados comunicam suas ideias e reclamações?

9. Sua organização sofreu alguma mudança nos últimos 3 anos? (aquisição, venda, fusão, relocalização ou cisão)? Como o RH participou desta (s) mudança (s)? 
10. Há alguma questão importante que não foi perguntada que queira acrescentar?

2. Questionário semi estruturado para entrevistas em profundidade - Sindicalistas Seção 1: Detalhes Pessoais

\begin{tabular}{|l|l|}
\hline 1.Sexo & \\
\hline 2.Idade & \\
\hline 3.Tempo de casa & \\
\hline 4. Qual é o seu cargo atual? & \\
\hline 5. Qual a sua formação educacional? & \\
\hline
\end{tabular}

6. Conte sua trajetória profissional.

Seção 2: Dados do sindicato

\begin{tabular}{|c|c|}
\hline Quantas pessoas são filiadas ao sindicato? & \\
\hline $\begin{array}{l}\text { Qual a proporção etária esta força de } \\
\text { trabalho? }\end{array}$ & $\begin{array}{l}18 \text { a } 24 \text { anos: } \\
25 \text { a } 49 \text { anos: } \\
50 \text { anos ou mais: }\end{array}$ \\
\hline Qual é a proporção da sua força de trabalho? & $\begin{array}{l}\text { a)Gerentes: } \_\% \\
\text { b)Profissionais (sem responsabilidade gerencial):___ } \% \\
\text { c)Administrativos e/ou operacionais: __ } \%\end{array}$ \\
\hline O mercado de refeições coletivas está: & $\begin{array}{l}\text { Diminuindo: } \\
\text { Sem Mudanças: } \\
\text { Crescendo: }\end{array}$ \\
\hline
\end{tabular}

Seção 3: Atividade do sindicato sobre o RH na organização e relações trabalhistas

1. Existe participação de um responsável do sindicato no Comitê executivo ou o equivalente no alto escalão de executivos? Se sim, como? Se não, por quê? 
2. Os sindicatos influenciam as organizações? Se sim, como? Se não, por quê? (Acordos coletivos, bancos de horas, data base, PLR ou outros?)

3. O sindicato dos trabalhadores tem contato com o RH das organizações? Como? Quando? Por quê? Com quem?

4. Como ocorrem as negociações com as organizações? Contratam preposto?

5. As organizações possuem comitê consultivo ou comissão de trabalhadores? Se sim, como? Se não, por quê?

6. Como os empregados comunicam suas ideias e reclamações ao sindicato?

7. As organizações sofreram alguma mudança nos últimos 3 anos? (aquisição, venda, fusão, relocalização ou cisão)? Como o sindicato participou desta (s) mudança (s)?

8. Há alguma questão importante que não foi perguntada que queira acrescentar? 